\title{
Advances in Multi-Omics Approaches for Molecular Breeding of Black Rot Resistance in Brassica oleracea L.
}

\section{Ranjan K. Shaw, Yusen Shen, Jiansheng Wang, Xiaoguang Sheng, Zhenqing Zhao, Huifang Yu and Honghui Gu*}

Institute of Vegetables, Zhejiang Academy of Agricultural Sciences, Hangzhou, China

OPEN ACCESS

Edited by:

Chunyu Zhang,

Huazhong Agricultural University,

China

Reviewed by:

Pilar Soengas,

Misión Biológica de Galicia, Consejo

Superior de Investigaciones

Cientificas (CSIC), Spain

Guangqin Cai,

Oil Crops Research Institute, Chinese Academy of Agricultural Sciences

(CAAS), China

Maoteng $\mathrm{Li}$

Huazhong University of Science and Technology, China

*Correspondence: Honghui Gu guhh2199@163.com

Specialty section:

This article was submitted to

Plant Breeding,

a section of the journal

Frontiers in Plant Science

Received: 16 July 2021 Accepted: 20 October 2021 Published: 06 December 2021

Citation:

Shaw RK, Shen Y, Wang J, Sheng $X$, Zhao Z, Yu H and Gu H

(2021) Advances in Multi-Omics Approaches for Molecular Breeding of Black Rot Resistance in Brassica

oleracea $L$.

Front. Plant Sci. 12:742553. doi: 10.3389/fpls.2021.742553
Brassica oleracea is one of the most important species of the Brassicaceae family encompassing several economically important vegetables produced and consumed worldwide. But its sustainability is challenged by a range of pathogens, among which black rot, caused by Xanthomonas campestris pv. campestris (Xcc), is the most serious and destructive seed borne bacterial disease, causing huge yield losses. Host-plant resistance could act as the most effective and efficient solution to curb black rot disease for sustainable production of B. oleracea. Recently, 'omics' technologies have emerged as promising tools to understand the host-pathogen interactions, thereby gaining a deeper insight into the resistance mechanisms. In this review, we have summarized the recent achievements made in the emerging omics technologies to tackle the black rot challenge in B. oleracea. With an integrated approach of the omics technologies such as genomics, proteomics, transcriptomics, and metabolomics, it would allow better understanding of the complex molecular mechanisms underlying black rot resistance. Due to the availability of sequencing data, genomics and transcriptomics have progressed as expected for black rot resistance, however, other omics approaches like proteomics and metabolomics are lagging behind, necessitating a holistic and targeted approach to address the complex questions of Xcc-Brassica interactions. Genomic studies revealed that the black rot resistance is a complex trait and is mostly controlled by quantitative trait locus (QTL) with minor effects. Transcriptomic analysis divulged the genes related to photosynthesis, glucosinolate biosynthesis and catabolism, phenylpropanoid biosynthesis pathway, ROS scavenging, calcium signalling, hormonal synthesis and signalling pathway are being differentially expressed upon Xcc infection. Comparative proteomic analysis in relation to susceptible and/or resistance interactions with $X_{c c}$ identified the involvement of proteins related to photosynthesis, protein biosynthesis, processing and degradation, energy metabolism, innate immunity, redox homeostasis, and defence response and signalling pathways in Xcc-Brassica interaction. Specifically, most of the studies focused on the regulation of the photosynthesis-related proteins as a resistance response in both early and later stages of infection. Metabolomic studies suggested that glucosinolates (GSLs), 
especially aliphatic and indolic GSLs, its subsequent hydrolysis products, and defensive metabolites synthesized by jasmonic acid (JA)-mediated phenylpropanoid biosynthesis pathway are involved in disease resistance mechanisms against $X_{C C}$ in Brassica species. Multi-omics analysis showed that JA signalling pathway is regulating resistance against hemibiotrophic pathogen like Xcc. So, the bonhomie between omics technologies and plant breeding is going to trigger major breakthroughs in the field of crop improvement by developing superior cultivars with broad-spectrum resistance. If multi-omics tools are implemented at the right scale, we may be able to achieve the maximum benefits from the minimum. In this review, we have also discussed the challenges, future prospects, and the way forward in the application of omics technologies to accelerate the breeding of $B$. oleracea for disease resistance. A deeper insight about the current knowledge on omics can offer promising results in the breeding of high-quality disease-resistant crops.

Keywords: Brassica oleracea, black rot, Xanthomonas campestris pv. campestris, omics, genomics, transcriptomics, proteomics, metabolomics

\section{INTRODUCTION}

Brassica oleracea is one of the most important species of the Brassicaceae family, encompassing several economically important vegetables such as cabbage, cauliflower, broccoli, kale, kohlrabi, and brussels sprouts. Among all these vegetables, cabbage, and cauliflower are widely produced while broccoli is relatively new and is emerging as a most sought vegetable in several countries. Brussels sprouts, kale, and kohlrabi though are not popular like the other three vegetables but are important on a regional or country basis (Quiros and Farnham, 2011). China and India are the highest producer of cauliflowers, broccoli, cabbages, and other Brassica vegetables with a total production of 44.85 and 18.21 million tonnes, respectively (FAOSTAT, 2019), followed by several other countries of Asia and Europe. Human selection has been helpful in creating a wide morphological variation within $B$. oleracea species. $B$. oleracea vegetables are extremely healthy and rich in nutrients with optimal health benefits. All these vegetables contain variable amount of vitamin, fiber, minerals, and useful phytochemicals (Cartea et al., 2011a; Gupta, 2011). In addition, this vegetable group is a rich source of sulfur-containing secondary metabolites, called glucosinolates (Kapusta-Duch et al., 2012) which possess anti-cancer properties. B. oleracea crops are highly sensitive to biotic stresses (fungal, bacterial, and viral) resulting in severe yield and quality losses. Among all, black rot is the most serious, destructive bacterial disease prevalent in many countries where $B$. oleracea crops are widely grown (Williams, 1980; Singh et al., 2011). Black rot was first reported in cabbage (Garman, 1894) and has spread to all regions of the world. So, black rot has a wide geographical distribution across the continents including Asia (China, India, Nepal, Taiwan), Europe (Italy, Spain, France, Belgium, Germany, Sweden, Hungary, Netherlands, Portugal, United Kingdom), Africa (Ethiopia, South Africa), North America (United States, Canada), South America (Brazil), and Australia (Saharan, 1993; Quiros and Farnham, 2011; Mulema et al., 2012; Singh et al., 2016; Akhtar et al., 2017) causing huge yield losses in cruciferous vegetables. The disease is also harmful in a way that it makes the plants prone to Alternaria blight attack (Sharma et al., 1991). The disease causes considerable yield losses up to $50-60 \%$ in cauliflower and affects the quality of the curd (Williams, 1980; Kashyap and Dhiman, 2010; Dhar and Singh, 2014), reducing its marketability. Several management strategies, including good cultural practices such as crop rotation, crop residue management, avoidance of water lodging, hot water and bactericide (e.g., sodium hypochlorite, hydrogen peroxide) treatment of seeds, and planting of disease-free materials (seeds or transplants), use of resistant varieties could be followed to reduce the spread of the disease. Among all, growing potentially Xcc-resistant cultivars could be the sustainable approach within the integrated management of disease and host-plant resistance can act as a key strategy to curb black rot disease. Advances in molecular biology and sequencing technologies in the postgenomics era can be exploited as powerful tools to tackle this challenge.

The recent development of genomic resources has led to the development of genetic/physical maps leading to the identification of several quantitative trait loci (QTLs) and candidate genes responsible for black rot resistance in B. oleracea. Rapid progresses were made in the 'omics' technologies at the genomic, transcriptomic, proteomic, and metabolomic levels permitting the researchers to identify the genetic underpinnings, i.e., genes to improve the productivity and quality of the crops. The emergence of omics technologies has enabled the researchers to have a direct and unbiased monitoring of the factors affecting the crop growth, yield, metabolism, biotic, and abiotic stresses (Setia and Setia, 2008). It has helped in the investigation of the biology behind several agronomic traits at the physiological, biochemical, and molecular levels accelerating the crop production. Omics approaches have shaped our understanding on the complex interactions between genes, proteins, and metabolites within the resulting phenotype (Emon, 2016). Omics helps in understanding the linkage between the genotypes and phenotypes and in studying the entire pathway eliciting the phenotypes (Guillemin et al., 2016). The knowledge generated from omics could be useful in understanding the complex pathways involved in disease resistance. Technological 
advances have driven the omics technologies to be cost-effective and carryout high-throughput analysis of biological samples (Hasin et al., 2017).

The recent advancement in next-generation sequencing (NGS) technologies has led to the publishing of many research articles in the field of different omics techniques. Consequently, a huge number of multi-omics data has been generated at the DNA, RNA, protein, and metabolite levels (Choi, 2019) which could be analysed to decipher the complex plant defence systems. In this era of big biological data, omics technologies are widely used for crop improvements in several major agricultural crops such as wheat (Alotaibi et al., 2021), allium (Khandagale et al., 2020), rice (Peng et al., 2020), sesamum (Dossa et al., 2017), and have revolutionized the modern agricultural research. This, in turn, are creating unprecedented opportunities for the plant researchers who can use the multi-omics data to decipher the multigenicity of biotic and abiotic plant stress responses, protein and metabolite profiles, and their dynamic changes in plants. The recent achievements in 'omics' technologies have opened up a plethora of possibilities to understand the complex $B$. oleracea$X c c$ interaction to develop resistant $B$. oleracea crops (Figure 1). However, many pitfalls and limitations exist to integrate and use these approaches, which need to be taken care of. Here, in this review, we are going to summarize the recent achievements made in the molecular breeding and emerging omics technologies to tackle the black rot challenge in B. oleracea. We have also discussed the challenges, future prospects, and the way forward in the application of omics technologies for accelerating the breeding of B. oleracea crops for disease resistance.

\section{BLACK ROT}

Black rot is one of the most serious and destructive bacterial diseases of $B$. oleracea prevalent in all agro-climatic zones of the world (Williams, 1980; Stall et al., 1993; Taylor et al., 2002; Singh and Dhar, 2011). Black rot caused by Xanthomonas campestris pv. campestris (Pammel) Dowson (hereinafter it will be referred as $X c c$ ) is a seed borne, gram-negative, aerobic, and vascular bacterium. Under favourable conditions of plenty rainfall, high humidity, and average temperature between 25 and $30^{\circ} \mathrm{C}$, the disease becomes more harmful leading to higher yield losses. Due to the curd infection, seed yield is also reduced drastically in cauliflower (Patel et al., 1970). Xcc attack reportedly decreases the biomass of $B$. oleracea seedlings at least 28 days after infection (Vega-Álvarez et al., 2021).

\section{Infection Process, Symptoms, and Disease Cycle of Xcc in Brassica}

$X c c$ infection can occur at any developmental stages of the plant, starting with germination of the infected seeds to maturity. $X c c$ primarily spreads from the infected seeds, which is a major route of disease transmission. However, black rot can also be transmitted through infested soil, crop residues, and by various environmental and mechanical means via wind, insects, aerosols, irrigation water, rain, and farm equipments (Vicente and Holub, 2013). The pathogen can survive longer in plant debris in soil than as free-living cells for up to 2 years. The germination of colonised seeds leads to the infection of the seedlings. The bacteria mostly enter the plants through the hydathodes on the leaf margins although it can also invade the plant through the wounds caused by machinery, insects, animals, rain, irrigation, and wind, etc. Through these entry points, the bacteria spread intercellularly, colonize the mesophyll first, and then gain access to the plant vascular systems and multiply in the vessels leading to the rapid spreading of systemic host infection. At the same time, the xylem disintegrates, spreading the bacteria between the surrounding parenchyma cells, killing the cells, and causing cavities to be formed (Agrios, 2005). The symptoms are manifested by very distinctive appearance, i.e., $\mathrm{V}$-shaped chlorotic to necrotic yellow lesions originating from the leaf margins and progressing toward the middle vein of the leaves. Also, the symptoms include the darkening of veins of the leaves and of the vascular tissue of the stem. Due to necrosis, the leaves fall prematurely, and systemic infection may lead to stunted growth of the plants. During warm and humid climates, Xcc thrives as a severe disease agent and the bacteria often ooze out to the surface of the leaves through the hydathodes/wounds and subsequently spread in droplets of guttation to the neighbouring plants by wind, rain, or water splashes. Black rot affecting different varieties of $B$. oleracea with the typical V-shaped lesion is depicted in Figures 2A-D.

Several pathogenic races of $X c c$ were reported in different Brassica species and Kamoun et al. (1992) first proposed the race structure of $X c c$. Initially, six races (1-6) were identified by Vicente et al. (2001). Later, three more races (7-9) were identified by Fargier and Manceau (2007) and recently, two novel races, race 10 and 11 were reported in Portugal (Cruz et al., 2017). Presently, eleven different physiological races infecting Brassica species have been reported (Vicente et al., 2001; Fargier and Manceau, 2007; Cruz et al., 2017), indicating the complexity of Xcc. Among all, races 1 and 4 are the most aggressive and predominant worldwide (Lema et al., 2012a; Vicente and Holub, 2013) though their frequencies in $B$. oleracea varies with the geographical region.

\section{RESISTANCE SOURCES AND GENETICS OF RESISTANCE}

As breeding of resistant varieties is one of the effective measures to control black rot, several studies were conducted to identify diverse resistance sources in $B$. oleracea. Since the first reporting of 'Early Fuji' as resistant to black rot (Bain, 1952), numerous resistance sources have been identified in B. oleracea. During the beginning of the 21st century, $X c c$ was differentiated in to pathogenic races and the researchers have been screening and identifying resistance sources specific to different races of $X c c$. But again, the problem is that a single resistant cultivar/line may not provide resistance to all the prevalent races of $X c c$. As races 1 and 4 are the most aggressive and prevalent in B. oleracea, extensive screening of the accessions was carried out to find out the novel resistance sources. Taylor et al. (2002) screened a large set of accessions of $B$. oleracea against race 1 and only a single accession showed partial resistance, indicating the rare 


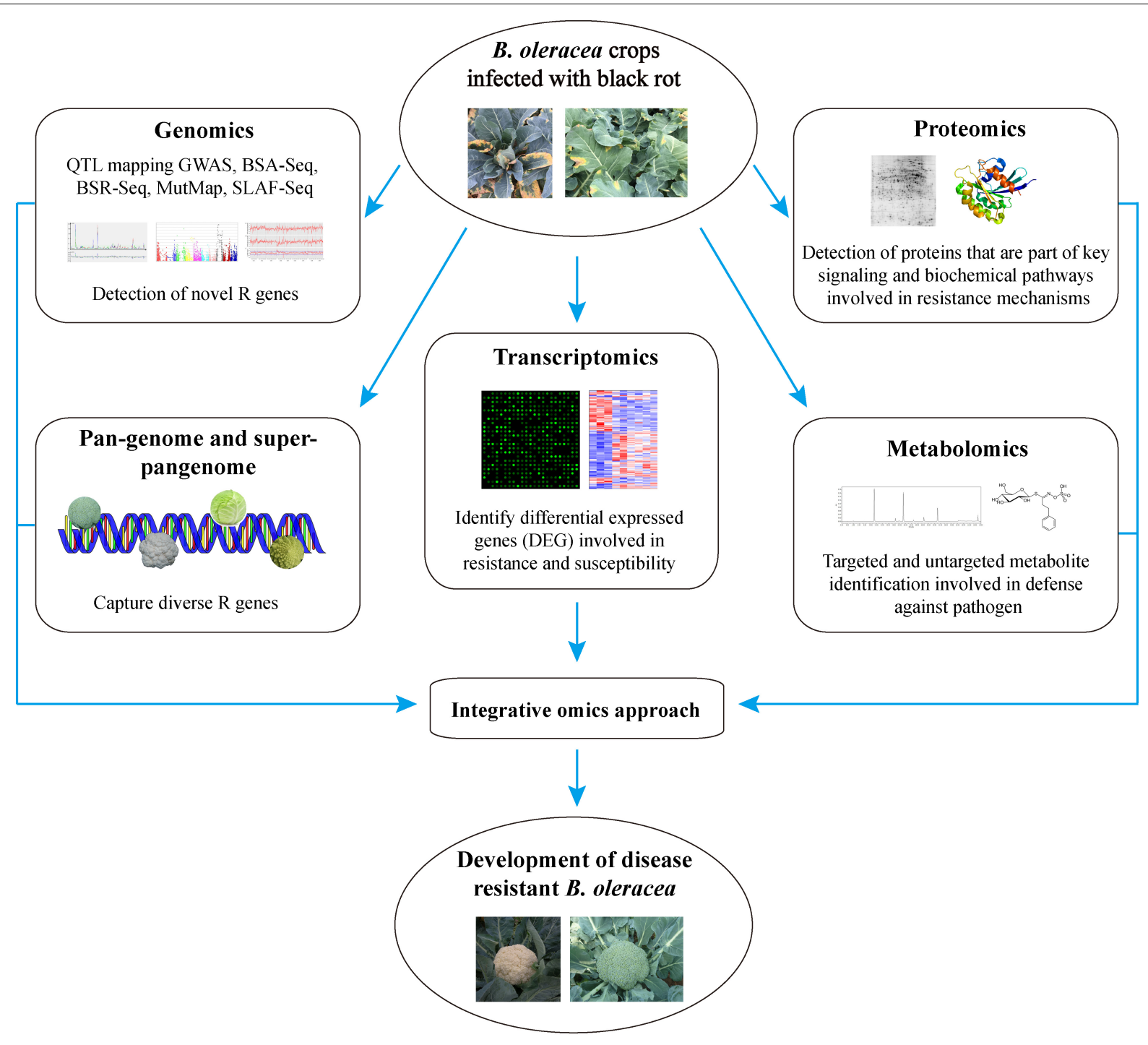

FIGURE 1 | The application of 'multi-omics' technologies to develop Xcc resistant B. oleracea and to understand the mechanisms of disease resistance.

existence of resistance sources for race 1 . Still, efforts were made to identify the resistance to race 1 and very recently, Kong et al. (2021) evaluated a worldwide collection of 162 cabbage accessions against race 1 and only four germplasms, including two inbred lines ('05-574-323' and 'MD219') and two hybrids ('Qinglian' and 'Dadilv 2'), were found to be highly resistant. In another study, out of 27 cabbage inbred lines, only one line (SCNU-C-4074) showed resistance to Xcc race 1 (Afrin et al., 2018a). Griesbach et al. (2003) identified one highly resistant cabbage, 'AU4518,' against race 1. In addition, different authors have screened and identified few accessions showing resistance to race 1 (Jensen et al., 2005; Lema et al., 2012b; Saha et al., 2016).

On contrary, screening of B. oleracea against Xcc4 identified only a few resistance sources. Taylor et al. (2002) couldn't identify a single accession conferring resistance to race 4 while screening a large set of $B$. oleracea accessions against a range of races of black rot. Recently, 26 cauliflower and six related wild species were screened against $X c c 4$ to identify novel sources of resistance. Among them, only one cauliflower inbred line (Boc4601) and three wild accessions (PI435896, UNICT5168, UNICT5169) showed better resistance (Sheng et al., 2020). Several scholars have screened and identified few resistant lines against Xcc4 in B. oleracea (Griesbach et al., 2003; Lema et al., 2012b; Saha et al., 2016). In contrast, comparatively a greater number of accessions of $B$. oleracea have been identified showing resistance to other races such as $1,2,3,5,6$, and 7 (Afrin et al., 2018a), and races 2, 3, 5, and 6 (Taylor et al., 2002). Resistance to races 3 and 5 is common in $B$. oleracea, especially in cauliflower (Taylor et al., 2002).

The rare existence of resistance to races 1 and 4 in the ' $C$ ' genome of B. oleracea (Taylor et al., 2002; Vicente and Holub, 2013) complicates the efficient control of black rot, necessitating to explore the novel sources of resistance in the related Brassica species. Most common and potentially useful sources of black rot 

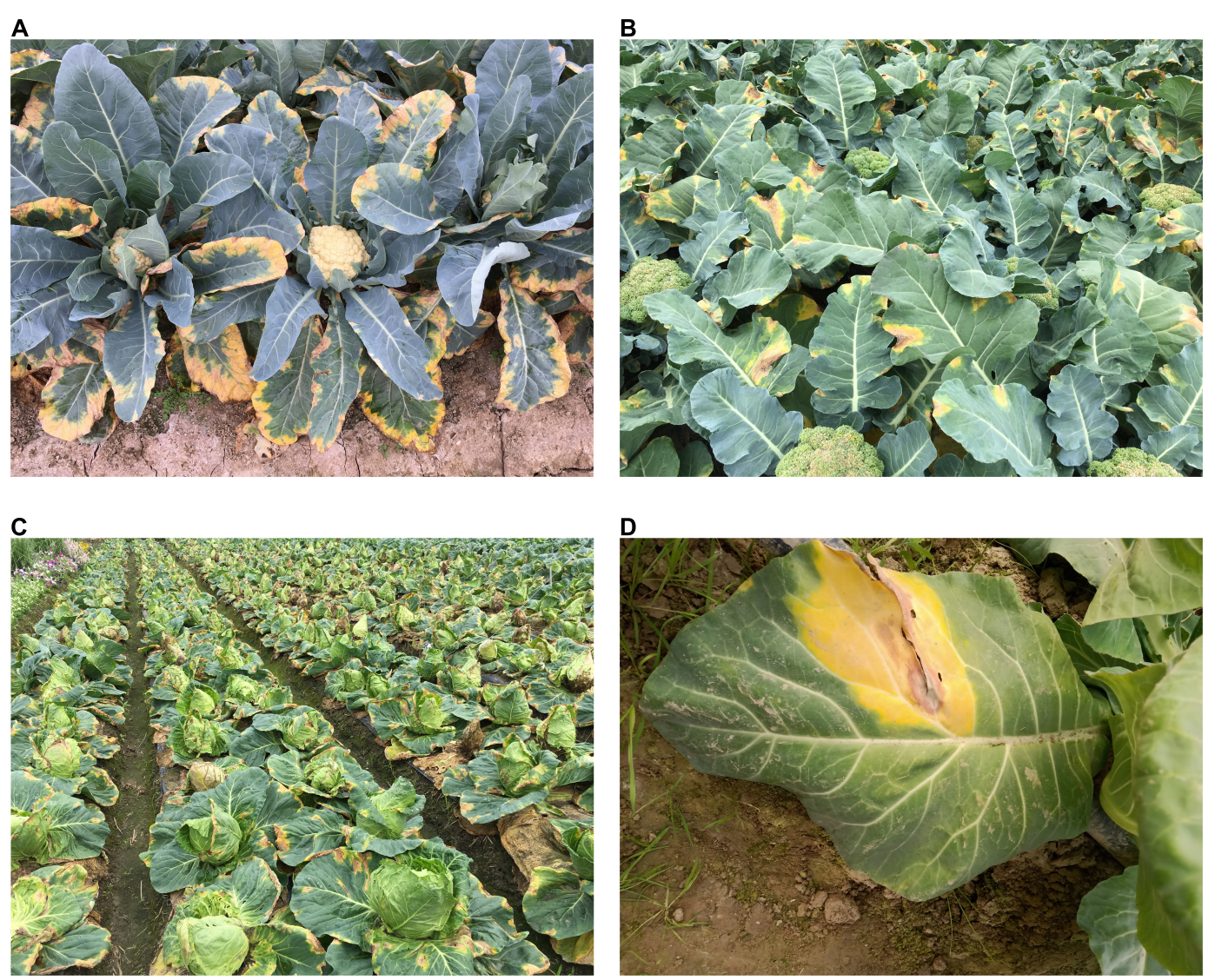

FIGURE 2 | Different Brassica oleracea varieties infested with Xanthomonas campestris pv. campestris [(A) Cauliflower plants with severe Xcc infection, (B) Broccoli plants with typical symptoms of $X_{C c}$, (C) Cabbage plants with heavy $X_{c c}$ infestation (D) Cauliflower leaves with characteristic V-shaped lesion caused by $X_{c c}$ infection].

resistance is available in the 'A' and 'B' genome of Brassica species. Several authors have reported the race-specific resistance to both races 1 and 4 of in related Brassica species such as B. nigra, $B$. rapa, B. carinata, and B. juncea (Ignatov et al., 2000; Taylor et al., 2002; Vicente et al., 2002; Tonguç and Griffiths, 2004; Griffiths et al., 2009). According to Taylor et al. (2002), resistance to races 1 and 4 were present in a high proportion in the ' $\mathrm{B}$ ' genomes (B. nigra, $B$. carinata, $B$. juncea) while strong resistance to race 4 has an 'A' genome origin (B. rapa, B. napus). The wild relatives of Brassica crops also could provide useful and durable sources of black rot resistance.

It is noteworthy that there could be certain limitations in using race-specific resistance materials in resistance breeding if only one specific resistance is prevalent in a target growing area. So, for durable resistance, accessions with broad-spectrum and race non-specific resistance are desirable (Taylor et al., 2002). In cauliflower, several race non-specific resistance sources have been identified (Sharma et al., 1972, 1977, 1995, 2003; Pandey et al., 2003; da Silva et al., 2015; Chatterjee et al., 2018). Also, in the 'A' and 'B' genomes of Brassica species, several durable resistance sources against $X c c$ have been reported (Westman et al., 1999; Taylor et al., 2002; Vicente and Holub, 2013; Dey et al., 2015; Lema et al., 2015; Sharma et al., 2016). Although the non-specific resistance is quantitative and durable, this is more difficult to manage and transfer between the cultivars.

Knowledge on the genetics of resistance guides in the resistance breeding to combat plant diseases. In $B$. oleracea, contradictory reports of the inheritance pattern of resistance genes in different genetic backgrounds and for different races have made the breeding for black rot resistance a challenging task. Worldwide, the widespread and predominant races 1 and 4 in B. oleracea collectively constitutes almost $94 \%$ of black rot disease (Vicente et al., 2001). Inheritance studies in B. oleracea varieties indicated the resistance to race 1 is controlled by a single dominant gene (Ignatov et al., 1998; Saha et al., 2014a,b, 2016), quantitative and recessive gene (Vicente et al., 2002), polygenes (Tonu et al., 2013), and a pair of additive major genes and additive-dominant multiple gene (Kong et al., 2021).

Resistance to race 4 was found to be governed by a single dominant gene (Vicente et al., 2002; Tonguç et al., 2003). But a recent study showed the prevalence of quantitative resistance against $X c c 4$ in an $\mathrm{F}_{2}$ population developed by a cross between wild species (Brassica montana) and cauliflower breeding line (Sheng et al., 2020). Resistance to race 3 of Xcc was controlled by a single dominant locus (Xca3) in doubled haploid line $\mathrm{BOH}$ $85 \mathrm{c}$ and PI 436606 of B. oleracea, whereas in Badger Inbred-16, 
the resistance to race 3 was found to be quantitative and recessive indicating the effect of genetic background (Vicente et al., 2002). Also, the same genotype showed different modes of inheritance to different races of black rot. Resistance of cabbage genotype 'PI436606' to Xcc race 1 and 3 was controlled by a single dominant gene (Ignatov et al., 1998; Vicente et al., 2002) whereas resistance to race 5 was reported to be controlled by a single recessive gene (Ignatov et al., 1998). Apart from this, the inheritance studies in cauliflower and cabbage have reported different modes of inheritance against black rot (without race information), such as single dominant gene (Jamwal and Sharma, 1986; Kaur et al., 2009), single recessive gene (Dickson and Hunter, 1987), polygenic dominant gene (Sharma et al., 1972; Tewari et al., 1979; Thakur et al., 2003), major genes with recessive and dominant modifiers (Williams et al., 1972), and non-additive genes (Pandey et al., 1995). Taken together, the genetics of black rot resistance is complex in B. oleracea and is genetically diverse. The inheritance pattern shows that both qualitative with a racespecific manner and quantitative resistance genes are responsible for black rot resistance.

\section{ADVANCES IN OMICS TECHNOLOGIES}

\section{Genomics}

Genomics pertains to the study of all the genes in a genome, including the identification of gene sequences, gene structures, and annotations. It plays an important role in discovering the genetic variation underlying important traits and contribute to the genetic improvement of crop species. Rapid progress in the NGS technologies has expanded our ability to understand the whole genome and helps in bridging the gap between the genotype and phenotype. Genomic revolution has led to the generation of whole-genome sequences, expressed sequence tags (ESTs), large-insert genomic libraries, high density genetic maps, and millions of molecular markers which could be used for bi-parental/association mapping, cloning of genes/QTLs, and genomic selection, etc. for agronomically important traits in different crops. The identification of QTLs, allelic variation in the genes governing the trait of interest will enhance the possibilities of improvement of Brassica species especially for disease resistance.

\section{Genome Assembly and Pangenomics}

Advancement in the NGS technologies has led to the sequencing of crop genomes of several Brassica species, such as B. oleracea (Liu et al., 2014; Parkin et al., 2014; Belser et al., 2018; Sun et al., 2019), B. rapa (Wang et al., 2011), B. nigra (Yang et al., 2016), B. napus (Chalhoub et al., 2014), and B. juncea (Yang et al., 2016). Several long-read sequencing technologies such as PacBio Single Molecule Real-Time sequencing (SMRT) (Roberts et al., 2013) and Oxford Nanopore Technologies (Jain et al., 2016) have revolutionized the Brassica genomics. The Brassica database, $\mathrm{BRAD}^{1}$, provides the information on the genome assemblies, predicted gene models, and gene annotations of 25 Brassica

${ }^{1}$ http://brassicadb.cn species (Cheng et al., 2011), helping plant scientists and breeders to efficiently use the information to understand the complex mechanisms underlying disease resistance. The molecular aspects of $B$. oleracea-pathogen interactions could be revealed by using high-quality reference genome assemblies generated for different morphotypes of $B$. oleracea over the past several years including kale (Parkin et al., 2014), cabbage (Cai et al., 2020; Lv et al., 2020; Guo et al., 2021), cauliflower (Sun et al., 2019; Guo et al., 2021), and broccoli (Belser et al., 2018). But the high-quality genome assemblies of the reference genome of $B$. oleracea may not represent all the morphotypes and capture only a fraction of them such as inflorescence in 'C-8' (Sun et al., 2019) and leafy type in 'TO1000' (Parkin et al., 2014) leaving other morphotypes, such as lateral leaf buds (brussels sprouts) and tuberous stems (kohlrabi) not having genome assemblies. This resulted in missing out of genetic diversity in $B$. oleracea species which could have been the potential source of genomic variation associated with black rot resistance.

Pangenome analysis in B. oleracea allows the identification of genes from a gene pool represented by many lines of the given species (Tao et al., 2019; Bayer et al., 2020) and may lead to the identification of orthologous genes in Brassica species (Golicz et al., 2016). The idea of pangenomics could help in overcoming the limitation of dependence on a single reference genome. The pangenome analysis of $B$. oleracea varieties revealed that in many genomes, a large proportion of the disease resistance genes were not present in all the lines (Golicz et al., 2016) suggesting the variable nature of R-genes. This may result in the loss of many candidate R-genes from a single reference genome. Interestingly, the pangenome study of $B$. oleracea found the wild relative (B. macrocarpa) harbouring the most resistance gene analog (RGA) indicating that the genetic resources of wild species of Brassica could be the repository of novel R-genes (Golicz et al., 2016; Bayer et al., 2019). Through pangenomic approach, Bayer et al. (2019) identified 37 RGA candidates within QTL regions associated with black rot and sclerotinia resistance in $B$. oleracea. The identified RGA candidates were not present in a single reference assembly indicating the requirement of a pangenome to identify the candidate genes for breeding of improved cultivars. The authors also revealed that RGA candidates differed between lines in $B$. oleracea and the single-nucleotide polymorphisms (SNPs) and presence/absence variants (PAV) drove RGA diversity using separate mechanisms.

Recently, Khan et al. (2020) reported a super-pangenome which included the genomes of wild relatives and different species within a genus which could be replicated in Brassica species. This may allow the broadening of the Brassica gene pool and will help in the identification of novel candidate resistance genes for several diseases including black rot by capturing the maximum genomic variation present within the Brassica species.

\section{Identification of Quantitative Trait Loci for Black Rot Resistance}

To exploit the genomic technologies in breeding programme, mapping of QTLs governing the desired traits and information about the allelic variation of genes underlying the target traits is crucial. Several advanced molecular breeding techniques such as 
marker-assisted selection (MAS), marker-assisted backcrossing (MABC), marker-assisted recurrent selection (MARS), and marker-assisted gene pyramiding (Collard and Mackill, 2008; Ye and Smith, 2008; Ribaut et al., 2010; Ragimekula et al., 2013) could help in achieving durable resistance against black rot using the latest genomic technologies. Progress in the NGS technologies have fast-tracked the identification of markers co-segregating with genes of interest. Identification of QTLs help in exploiting the closely linked markers through markerassisted selection in breeding programme (Collard et al., 2005; Collard and Mackill, 2008) and permits the validation of QTLs and its effect across a range of environments and genetic backgrounds.

As discussed earlier, races 1 and 4 of black rot is considered as the most virulent and widespread races in B. oleracea (Lema et al., 2012a; Vicente and Holub, 2013). So, several studies were framed to identify the R-genes/QTLs and markers linked to $X c c 1$ and $X c c 4$ resistance in $B$. oleracea, most importantly in cauliflower by different research groups (Table 1). Several random amplified polymorphic DNA (RAPD) markers linked to $X c c 1$ resistance locus were reported by various researchers. Saha et al. (2014b) mapped a Xcc1 resistance locus, Xcalbo on chromosome 3 in Indian cauliflower by bulk segregant analysis. Two markers (RAPD $04_{833}$ and ISSR $11_{635}$ ) were found flanking the resistance locus at $1.6-\mathrm{cM}$ interval. Based on sequence homology with $B$. rapa genome, the location of $X c a 1 b o$ was deduced to chromosome 3 in $B$. oleracea. The identified markers have the potential to be used in markerassisted backcross breeding programme for introgression of the black rot (race 1) resistance. Again, Saha et al. (2014a) identified three RAPD markers (OPO-04833, OPAW-202 238 , and OPG$25_{625}$ ) controlling resistance to $X c c$ race 1 which were associated in coupling phase to the resistance allele and was found cosegregating with the black rot resistance gene. RAPD markers are dominant in nature, so they need to be converted into sequence characterized amplified region (SCAR) markers for utility purpose. Two sequence characterized amplified regions (SCAR) markers (ScOPO-04833 and ScPKPS-11635) were identified in close linkage with the black rot resistance locus, Xca1Bo (resistance to $X c c 1$ ), in cauliflower (Kalia et al., 2017). This was the first report of SCAR markers found to be tightly linked to black rot resistance locus $(X \mathrm{ca} 1 \mathrm{Bo})$ in cauliflower. Interestingly, these markers showed $100 \%$ accuracy in differentiating the resistant and susceptible plants of cauliflower breeding lines. Very recently, the SCAR marker, ScOPO-04833, was used as a foreground marker to introgress the black rot-resistance gene $(X c a 1 b o)$ during marker-assisted pyramiding of black rotresistance gene $X c a 1 b o$ and downy mildew-resistance gene Ppa3 in popular early cauliflower variety Pusa Meghna (Saha et al., 2021).

All the above researchers reported the simple genetic control or qualitative resistance against $X c c 1$ which is desirable for effective production of black rot resistant hybrids. Xcc infects the plants mainly through hydathodes and colonizes the epitheme and kills the host cell by degrading the cell walls. According to Bae et al. (2015), the rapid destruction of epitheme cell may cause the expression of any R-gene expression ineffective. In rice, the R-genes have lost their qualitative feature against a virulent strain of Xanthomonas oryzae pv. oryzae and had adopted a new, intermediate resistance phenotype (Li et al., 1999). This signifies the importance of quantitative resistance against $X c c$, and several authors have shown that resistance to $X c c 1$ is quantitative and under polygenic control. Doullah et al. (2011) mapped the QTLs controlling resistance to $X c c$ (later revealed as race 1 by Tonu et al., 2013) and identified two significant QTLs on LG2 and LG9 in B. oleracea. These QTLs were compared with already identified QTLs by Camargo et al. (1995). Interestingly, the QTL on LG9 corresponded to the QTL interval (between wg6g5-wg2g11) on LG 1 identified by Camargo et al. (1995) enhancing its utility in marker-assisted selection for black rot resistance. Again Tonu et al. (2013) analysed the Xcc 1 resistance QTLs in B. oleracea by improving an $\mathrm{F}_{2}$ population map developed by Doullah et al. (2011) and carried out comparative analysis of the mapped QTLs using common markers. This has led to the development of common markers ( $\mathrm{pW}, \mathrm{pX}$, and BoCL) closely linked with the previously reported QTLs and could be used as anchor markers to compare the map position of $X c c 1$ resistance QTLs. The authors obtained two major QTLs: $X c c B o($ Reiho $) 2$ and $X c c B o(G C) 1$, and one minor QTL: XccBo(Reiho)1 on chromosome C8, C9, and $\mathrm{C} 5$, respectively. Based on the common markers, the QTL $X c c B o($ Reiho 1 corresponded to QTL-LG2a and QTL-3, identified by Camargo et al. (1995) and Kifuji et al. (2013), respectively. Kifuji et al. (2013) mapped one major QTL (QTL-1) for Xcc1 resistance on linkage group C2 in two consecutive years explaining 15.05 and $9.88 \%$ of phenotypic variance, respectively. Two minor QTLs, QTL-2 (LG C4) and QTL-3 (LG C5), were also reported. Interestingly, the $Q T L-1$ region showed synteny with a region spanning from 5.3 to $7.4 \mathrm{Mb}$ on the short arm end of chromosome 5 of Arabidopsis thaliana, which was rich in genes of TIR-NBS-LRR family. In another study, dCAPS markers developed from candidate SNPs were used to improve the resolution of a previously developed genetic map and QTL analysis identified one major (BRQTL-C1_2) and three minor QTLs (BRQTL-C1_1, BRQTL-C3, and BRQTL-C6) containing 21 candidate resistance genes (Lee et al., 2015).

The most comprehensive study to dissect quantitative resistance to $X c c 1$ was carried out by Iglesias-Bernabé et al. (2019). The authors measured five traits, such as initial stages of invasion, success of infection, and spread of the pathogen, in the BolTBDH mapping population and identified four single-trait QTLs (Xcc1.1, Xcc6.1, Xcc8.1, Xcc9.1) on linkage group $1,6,8$, and 9 confirming the quantitative nature of $X c c 1$ resistance as reported by the previous authors. Three QTLs, except Xcc9.1, were identified previously. Multi-trait QTL analysis revealed that the spread of $X c c$ is related to the size of the leaf. Two resistance strategies were followed by the genotypes of the mapping population to keep up with the disease progression; reducing the lesion size or maintaining more area of the leaf with photosynthetic activity to be more tolerant to Xcc invasion. Also, the authors showed that the resistance mechanisms contributing to variation of resistance could be related to different aspects of plant immunity, including the synthesis of glucosinolates (GSLs) and phenolics. 
TABLE 1 | List of quantitative trait loci (QTLs)/R-genes associated with black rot resistance in Brassica oleracea and related Brassica species.

\begin{tabular}{|c|c|c|c|c|c|c|c|c|}
\hline Disease & Species & Cultivar & $\begin{array}{l}\text { Mapping } \\
\text { population }\end{array}$ & $\begin{array}{l}X c c \\
\text { race }\end{array}$ & $\begin{array}{l}\text { Gene } \\
\text { locus/QTL }\end{array}$ & Chr/LG & Linked marker & References \\
\hline \multirow[t]{8}{*}{$\begin{array}{l}\text { Black rot } \\
\text { Xanthomonas } \\
\text { campestris pv. } \\
\text { campestris } \\
\text { (Pammel) } \\
\text { Dowson }\end{array}$} & $\begin{array}{l}\text { Brassica } \\
\text { oleracea }\end{array}$ & $\begin{array}{l}\text { Bl-16 } \\
\text { (resistant) } \times \text { OSU Cr-7 } \\
\text { (susceptible) }\end{array}$ & F3 & - & - & $\begin{array}{l}\text { LG1, LG2, } \\
\text { LG9 }\end{array}$ & $\begin{array}{l}\text { wg2g11, wg6g5, } \\
\text { wg6g5, wg1e3b, } \\
\text { ec5e12, ec2h2, wg6h1, } \\
\text { tg4d2b, wg8a9b, } \\
\text { wg4d7, ec2d9, } \\
\text { wg8a9b }\end{array}$ & $\begin{array}{l}\text { Camargo } \\
\text { et al., } 1995\end{array}$ \\
\hline & $\begin{array}{l}\text { Brassica } \\
\text { oleracea } \\
\text { var. } \\
\text { capitata }\end{array}$ & $\begin{array}{l}\text { January King } \\
\text { (resistant) } \times \text { Golden } \\
\text { Acre (susceptible) }\end{array}$ & $\mathrm{F} 2$ & - & - & - & $C-11_{1000}$ & $\begin{array}{l}\text { Kaur et al., } \\
2009\end{array}$ \\
\hline & $\begin{array}{l}\text { Brassica } \\
\text { oleracea }\end{array}$ & $\begin{array}{l}\text { GC P09 } \\
\text { (susceptible) } \times \text { Reiho } \\
\text { P01 (tolerant) }\end{array}$ & $\mathrm{F} 2$ & 1 & $\begin{array}{l}\text { XccBo(Reiho)2, } \\
X_{c c B o(R e i h o) 1,} \\
X_{c c B o}(G C) 1\end{array}$ & $\begin{array}{l}\text { C08, C05, } \\
\text { C09 }\end{array}$ & $\begin{array}{l}\text { BoGMS1330, } \\
\text { BoGMS0971, } \\
\text { CB10459 }\end{array}$ & $\begin{array}{l}\text { Tonu et al., } \\
2013\end{array}$ \\
\hline & $\begin{array}{l}\text { Brassica } \\
\text { oleracea } \\
\text { var. } \\
\text { botrytis }\end{array}$ & $\begin{array}{l}\text { Pusa Himjyoti } \\
\text { (susceptible) } \\
\times \text { BR-161 (resistant) }\end{array}$ & $\mathrm{F} 2$ & 1 & - & - & $\begin{array}{l}\text { OPO-04833, } \\
\text { OPAW-202538, } \\
\text { OPG-25625 }\end{array}$ & $\begin{array}{l}\text { Saha et al., } \\
2014 a\end{array}$ \\
\hline & $\begin{array}{l}\text { Brassica } \\
\text { oleracea } \\
\text { var. } \\
\text { botrytis }\end{array}$ & $\begin{array}{l}\text { Pusa Himjyoti } \\
\text { (susceptible) } \times \text { BR- } \\
161 \\
\text { (Resistant) }\end{array}$ & F2 & 1 & Xca1bo & - & $\begin{array}{l}\text { ScOPO- } 04_{833} \\
\text { ScPKPS-11635 }\end{array}$ & $\begin{array}{l}\text { Kalia et al., } \\
2017\end{array}$ \\
\hline & $\begin{array}{l}\text { Brassica } \\
\text { oleracea }\end{array}$ & $\begin{array}{l}\text { TO1000DH3 } \times \text { Early } \\
\text { Big }\end{array}$ & $\mathrm{DH}$ & 1 & $\begin{array}{l}X_{c c 1} 1, X_{c c 6} .1 \\
X_{c c 8.1}, X_{c c 9} .1\end{array}$ & $\begin{array}{l}\text { LG1 (C01), } \\
\text { LG6 (C06), } \\
\text { LG8 (C08), } \\
\text { LG9 (C09) }\end{array}$ & - & $\begin{array}{l}\text { Iglesias- } \\
\text { Bernabé } \\
\text { et al., } 2019\end{array}$ \\
\hline & $\begin{array}{l}\text { Brassica } \\
\text { oleracea }\end{array}$ & $\begin{array}{l}\text { Twenty-seven different } \\
\text { cabbage } \\
\text { inbred lines }\end{array}$ & Inbred lines & $\begin{array}{l}1,2,3 \\
4,5,6 \\
\quad 7\end{array}$ & - & $\begin{array}{l}\mathrm{C} 01, \mathrm{C} 03 \\
\mathrm{C} 06, \mathrm{C} 08\end{array}$ & $\begin{array}{l}\text { BnGMS301, } \\
\text { BoESSR726, } \\
\text { BoESSR291, } \\
\text { Ol10G06, BoGMS0971 }\end{array}$ & $\begin{array}{l}\text { Afrin et al., } \\
2018 \text { a }\end{array}$ \\
\hline & $\begin{array}{l}\text { Brassica } \\
\text { rapa }\end{array}$ & - & $\mathrm{F} 2$ & 4 & R4 & - & WE22, WE49 & $\begin{array}{l}\text { Ignatov et al., } \\
2000\end{array}$ \\
\hline
\end{tabular}


TABLE 1 | (Continued)

\begin{tabular}{|c|c|c|c|c|c|c|c|c|}
\hline Disease & Species & Cultivar & $\begin{array}{c}\text { Mapping } \\
\text { population }\end{array}$ & $\begin{array}{l}X c c \\
\text { race }\end{array}$ & $\begin{array}{l}\text { Gene } \\
\text { locus/QTL }\end{array}$ & Chr/LG & Linked marker & References \\
\hline & $\begin{array}{l}\text { Brassica } \\
\text { rapa }\end{array}$ & $\begin{array}{l}\text { R-o-18 } \\
\text { (susceptible) } \times \text { B162 } \\
\text { (resistant) }\end{array}$ & $\mathrm{F} 2$ & 1 & $\begin{array}{l}X_{c c R 1 d-1} \\
X_{c c R} 1 i-1\end{array}$ & A06 & $\begin{array}{l}\text { E11M50_280b, } \\
\text { E12M48_171r }\end{array}$ & $\begin{array}{l}\text { Soengas } \\
\text { et al., } 2007\end{array}$ \\
\hline & $\begin{array}{l}\text { Brassica } \\
\text { rapa }\end{array}$ & $\begin{array}{l}\text { R-o-18 } \\
\text { (susceptible) } \times \text { B162 } \\
\text { (resistant) }\end{array}$ & $\mathrm{F} 2$ & 4 & $\begin{array}{l}X_{c c R} 4 d-1 \\
X_{c c R} 4 i-1\end{array}$ & A06 & $\begin{array}{l}\text { E12M61_215b, } \\
\text { E12M61_215b }\end{array}$ & $\begin{array}{l}\text { Soengas } \\
\text { et al., } 2007\end{array}$ \\
\hline & $\begin{array}{l}\text { Brassica } \\
\text { rapa }\end{array}$ & $\begin{array}{l}\text { R-o-18 } \\
\text { (susceptible) } \times \text { B162 } \\
\text { (resistant) }\end{array}$ & $\mathrm{F} 2$ & 4 & $X_{c c R} 4 i-2$ & $\mathrm{~A} 02$ & E11M59_178r & $\begin{array}{l}\text { Soengas } \\
\text { et al., } 2007\end{array}$ \\
\hline & $\begin{array}{l}\text { Brassica } \\
\text { rapa }\end{array}$ & $\begin{array}{l}\text { R-o-18 } \\
\text { (susceptible) } \times \text { B162 } \\
\text { (resistant) }\end{array}$ & $\mathrm{F} 2$ & 4 & XccR4i-3 & A09 & E12M48_1 > 330b & $\begin{array}{l}\text { Soengas } \\
\text { et al., } 2007\end{array}$ \\
\hline & $\begin{array}{l}\text { Brassica } \\
\text { rapa }\end{array}$ & $\begin{array}{l}175 \times \mathrm{P} 143 \text { and } \\
\mathrm{P} 115 \times 143\end{array}$ & $\mathrm{DH}$ & $\begin{array}{c}1,3,4 \\
6\end{array}$ & $\begin{array}{l}13 \text { QTL (DH30), } \\
19 \text { QTL (DH38) }\end{array}$ & $\begin{array}{l}\mathrm{A} 01, \mathrm{~A} 02, \\
\mathrm{~A} 03, \mathrm{~A} 04, \\
\mathrm{~A} 05, \mathrm{~A} 06, \\
\mathrm{~A} 07, \mathrm{~A} 08, \\
\mathrm{~A} 09, \mathrm{~A} 10\end{array}$ & Many & $\begin{array}{l}\text { Artemyeva } \\
\text { et al., } 2018\end{array}$ \\
\hline & $\begin{array}{l}\text { Brassica } \\
\text { carinata }\end{array}$ & $\begin{array}{l}\text { NPC-17 } \\
\text { (susceptible) } \times \text { NPC-9 } \\
\text { (resistant) }\end{array}$ & $\mathrm{F} 2$ & 1 & Xca1bc & $\begin{array}{l}\text { LG7 (B } \\
\text { genome) }\end{array}$ & $\begin{array}{l}\text { At1g70610, } \\
\text { At1g71865, } \\
\text { Na14-G02 }\end{array}$ & $\begin{array}{l}\text { Sharma et al., } \\
2016\end{array}$ \\
\hline & $\begin{array}{l}\text { Brassica } \\
\text { napus }\end{array}$ & $\begin{array}{l}\mathrm{N}-0-9 \\
\text { (susceptible) } \times \mathrm{N}-\mathrm{o}-1 \\
\text { (resistant) }\end{array}$ & $\mathrm{DH}$ & 4 & Xca4 & N5 (A genome) & - & $\begin{array}{l}\text { Vicente et al., } \\
2002\end{array}$ \\
\hline
\end{tabular}

Compared to $X c c 1$, few studies were conducted to identify QTLs for $X c c 4$ in $B$. oleracea. As the resistance to races 4 is scanty in B. oleracea, a resistant line (11B-1-12) was developed by transferring black rot resistance from B-genome of $B$. carinata (provides complete protection against races 1 and 4 of $X c c$ ) to B. oleracea by protoplast fusion (Hansen and Earle, 1995). This resistance line (11B-1-12) was used to develop three $F_{2}$ populations in $B$. oleracea and eight polymorphic RAPD markers were found linked with completely black rot (Xcc4) free plants (Tonguç et al., 2003). The segregation pattern of the linked markers suggested the role of a single dominant major gene governing resistance to $X c c 4$.

There is a dearth of durable resistance sources in the ' $C$ ' genome of $B$. oleracea for different $X c c$ races (Soengas et al., 2007). However, 'A' and 'B' genomes of Brassica species are the sources of resistance genes, and several QTLs conferring resistance to black rot were mapped in the related Brassica species (Table 1). In B. rapa ('A' genome), both race-specific and broad-spectrum resistance against six races have been frequently observed. Soengas et al. (2007) identified four highly significant QTLs (two for race 1 and two for race 4) on chromosome A06 using an $\mathrm{F}_{2}$ mapping population of 114 plants. Two additional QTLs for resistance to race 4 were found on linkage group A02 and A09. The authors opined that the markers closely linked to the QTLs may assist in the transfer of resistance into different cultivars of $B$. oleracea. Recently, Sharma et al. (2017), while exploring the 'A' and 'B' genomes of Brassica species to transfer black rot resistance into cauliflower, introgressed a single dominant black rot resistance gene, $X c a 1 b c$, through interspecific hybridisation between cauliflower (Pusa Sharad) and Brassica carinata (NPC-9), followed by embryo rescue. A marker 'At1g70610' linked with resistance against Xcc race 1 (Sharma et al., 2016) was used to confirm the successful introgression of black rot resistance in the interspecific $\mathrm{BC} 1$ population.

Recently, Afrin et al. (2018a) screened 27 inbred lines resistant to different races of black rot $(1,2,3,4,5,6,7)$ using 9 simple sequence repeats (SSRs) and 1 insertiondeletions (inDels) markers, and based on the bioassay and molecular screening results, five markers were selected capable of distinguishing the resistant lines from the susceptible ones of cabbage consistently.

Often, loci for black rot resistance identified in green house screening are not detected under field conditions. This could be due to greater experimental error in the field experiments and lower resolution of visual rating scale during field scoring (Horsfall and Cowling, 1978; Jamwal and Sharma, 1986). In this backdrop, Camargo et al. (1995) mapped the QTLs controlling resistance to Xcc in field, glasshouse, and genomic regions were identified on LG 1 and 9 associated with both young and adult plant resistance and two additional QTLs (QTL-LG2a, QTL$L G 2 b)$ on LG2 were associated with the young plant resistance. The results mostly indicated that plants selected based on young plant screening should reflect the adult-plant resistance.

In summary, we observed that several QTLs, both with major and minor effects, have been mapped to different chromosomes of $B$. oleracea suggesting that the resistance to black rot is a complex trait. Furthermore, though several QTL mappings were conducted in both B. oleracea and related Brassica species, so far, no resistance gene has been cloned. Basically, R-genemediated effector-triggered immunity (ETI) is considered as the most effective in conferring resistance to plants (Debieu et al., 2016). However, ETI fails to provide durable and broad-spectrum 
resistance shifting the attention toward quantitative resistance. In $B$. oleracea, black rot resistance is mostly considered to be under quantitative control. However, with the available information of markers/QTLs for black rot resistance, we can say that the information is limited, especially QTLs imparting resistance to race 4 of $X c c$ need to be identified. Also, emergence of new races of $X c c$ is a major factor hindering the deployment of the QTLs in resistance breeding of $X c c$.

Nevertheless, all the above information of markers/QTLs identified in $B$. oleracea will help in the understanding of the molecular mechanisms of disease response in $B$. oleracea under Xcc stress. Introgression of both race-specific and race non-specific genes into the background of susceptible $B$. oleracea cultivars could help in conferring broad-spectrum resistance. Also, the information about the QTLs and linked molecular markers will undoubtedly aid in the introgression of resistance into the elite cultivars of $B$. oleracea to develop resistant varieties.

\section{Identification of Candidate Nucleotide-Binding Site-Leucine-Rich Repeat Encoding R genes for Black Rot Resistance}

Plants defend themselves from a variety of microbial pathogens by employing two types of resistance: qualitative and quantitative resistance. Qualitative resistance is governed by R-gene-mediated defence where R-genes convey disease resistance by producing $\mathrm{R}$ proteins against the plant pathogens. Upon pathogen attack, the phytopathogens produce certain molecules called 'effectors', encoded by Avr (avirulence) genes which are recognised by R-genes and activate the effector-triggered immunity (ETI). This interaction is also known as "gene-for-gene" model for plant disease resistance (Flor, 1971), and such types of interactions have been observed between the avr genes $(A 1-A 5)$ of $X c c$ and the corresponding $R$-genes $(R 1-R 5)$ of several Brassica cultivars (Fargier and Manceau, 2007; Vicente and Holub, 2013). The main class of the R-genes consists of nucleotide-binding site-leucinerich repeat (NBS-LRR) proteins (Van der Biezen and Jones, 1998; Dangl and Jones, 2001; Yu et al., 2014) and are widely distributed in plants. While the nucleotide-binding site (NBS) domain can bind and hydrolyse ATP/GTP, the leucine-rich repeat (LRR) domain is involved in protein-protein interactions (Tameling et al., 2002; Wan et al., 2012). Based on N-terminal structures, the NBS-LRR type R-genes were further subdivided into coiled-coilnucleotide-binding site-leucine-rich repeat (CC-NB-LRR) type and toll/interleukin-1 receptor-nucleotide-binding site-leucinerich repeat (TIR-NB-LRR) type (Dangl and Jones, 2001). Izzah et al. (2014) identified 29 expressed sequenced tags (ESTs) containing NBS-LRR domains, among which, 22 were TIRNBS-LRRs and 7 were CC-NBS-LLRs type in the black rot resistant cabbage line C1234. Lee et al. (2015) reported 21 different NBS-LRR genes within four resistance QTL regions against $X c c$ in cabbage. Of the detected 21 R-genes, nine were present in gene clusters. Eight NBS-LRR encoding genes were identified in the BRQTL-C1_1 and BRQTL-C1_2 QTLs, seven and five NBS-LRR type R-genes were detected near the $B R Q T L-C 3$ and BRQTL-C6 region, respectively. Importantly, comparison of these 21 candidate genes against Brassica database showed the sequence similarity to disease resistance proteins. In another study, DNA sequence variation and expression of 31 NBS-encoding genes were analysed in cabbage, which encoded TIR, NBS, LRR, and RPW8 protein domains and nine NBSencoding R-genes (Bol003711, Bol010135, Bol010559, Bol022784, Bol029866, Bol042121, Bol031422, Bol040045, and Bol042095) were identified presumed to be involved in black rot resistance (Afrin et al., 2018b). NBS-LRR genes, after recognizing the pathogen, triggers various defence signal transductions leading to hypersensitive response (Sagi et al., 2017). These R-genes regulate phytohormone signalling to counteract the pathogenic infection (Joshi and Nayak, 2011). During host-pathogen interactions, different calcium signalling genes regulate the plant defence (Tortosa et al., 2019). Mamun et al. (2020) hypothesized that R-genes were involved in calcium signalling and hormonal regulation in triggering ETI response and disease susceptibility in the B. napus-Xcc pathosystem (Figures 3A,B). The expression analysis of R-genes, ZAR1 (CC-NB-LRR-type) and TAO1 (TIRNB-LRR-type), in two contrasting genotypes of $B$. napus revealed that ZAR1 was involved in the resistance interaction through calcium-sensing receptor (CAS) and calmodulin (CaM) to initiate salicylic acid (SA) synthesis and signalling, thereby inducing JA synthesis and signalling, and resulting in ETI response. On the contrary, TAO1 mediated the SA accumulation through calcium-sensing receptor (CAS) and calcium-sensing protein $60 \mathrm{~g}$ (CBP60g), with an antagonistic depression of JA leading to disease susceptibility.

However, ETI often fails to deliver durable and broadspectrum resistance if the trait is governed by polygenic resistance, shifting the focus toward resistance QTLs. As discussed earlier, resistance to $X c c$ in most of the B. oleracea lines was disclosed to be under quantitative control. The durability of quantitative resistance could happen due to the exertion of a low selection pressure on the pathogen population and difficulties to overcome the combination of different resistance-associated mechanisms by the pathogens (Palloix et al., 2009; Mundt, 2014). Resistance QTLs were also reported to be specific or nonspecific to a pathogen, and some QTLs can show resistance to multiple pathogens (Ellis et al., 2014; Wiesner-Hanks and Nelson, 2016). In several systems, combination of both broadspectrum and isolate-specific QTLs resulting in quantitative resistance have been reported (Caranta et al., 1997; Calenge et al., 2004; Rocherieux et al., 2004). The genes accounting for quantitative resistance represent a broad range of possible functions for the genes underlying resistance QTLs, such as basal defence, detoxification, transduction of defence signals, or partially altered major R-genes (Niks et al., 2015; French et al., 2016). In Arabidopsis thaliana, Resistance related KinaSe1 (RKS1) conferred quantitative resistance against the races 1, 3, 5, 7, and 9 of Xcc (Huard-Chauveau et al., 2013). RKS1 encodes an atypical kinase lacking the critical domains required for kinase catalytic core during catalysis (Roux et al., 2014). Recently, Debieu et al. (2016) identified two major QTLs that conferred resistance specifically to races 2 and 6 of Xcc. The study revealed that the quantitative disease resistance to race 6 involves the wellknown immune receptor pair RRS1/RPS4. In addition to RKS1, three genes with different range of specificity were involved in 

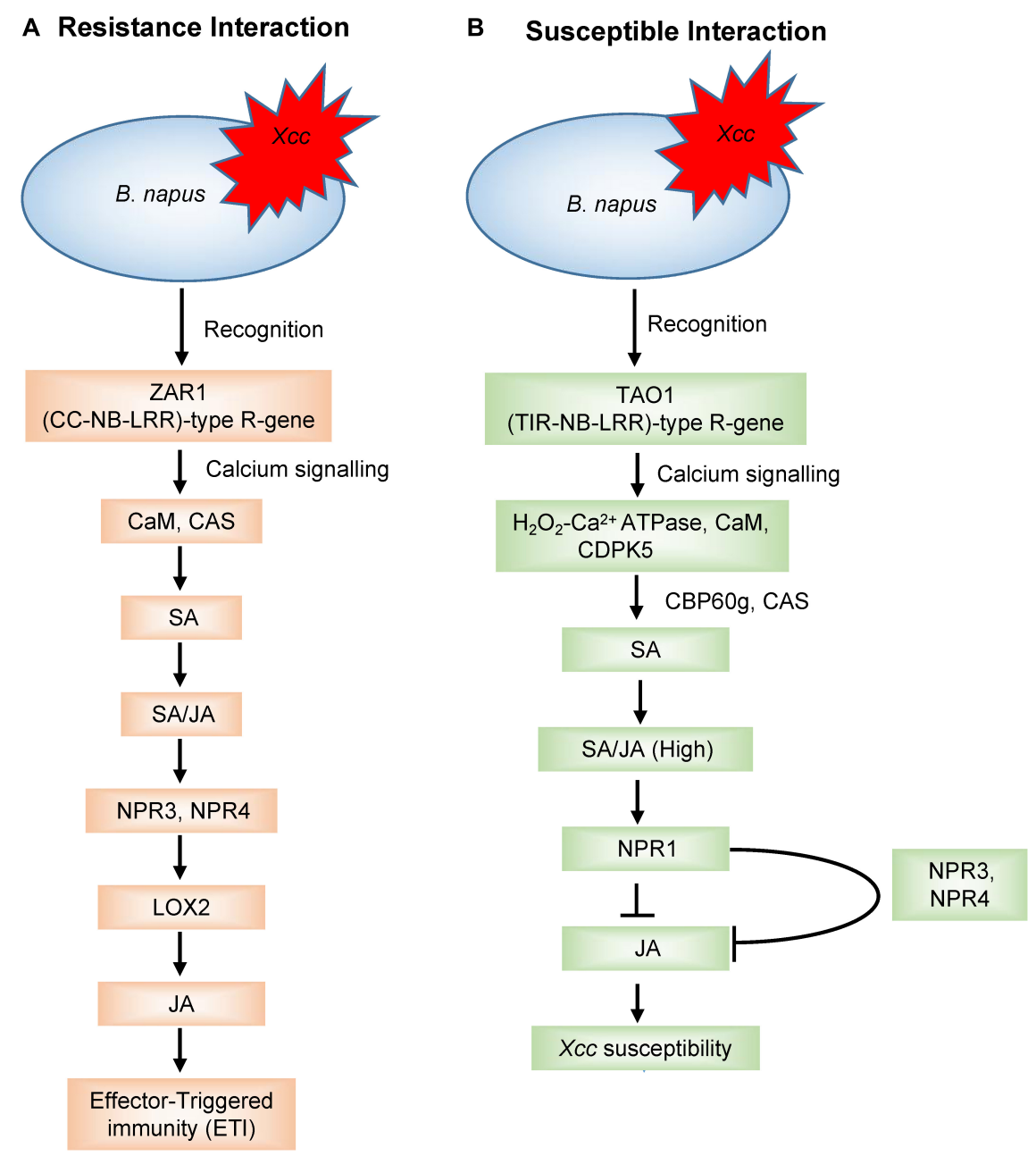

FIGURE 3 | A model outlining the R-gene-mediated signalling to (A) induce effector-triggered immunity (ETI) and (B) disease susceptibility upon XCC inoculation in Brassica napus as proposed by Mamun et al. (2020). JA, jasmonic acid; SA, salicylic acid; CaM, calmodulin; CAS, calcium-sensing receptor; NPR1, non-expressor of pathogenesis-related gene 1; NPR3, non-expressor of pathogenesis-related genes 3; NPR4, non-expressor of pathogenesis-related genes 4; LOX2, lipoxygenase 2; CDPK5, calcium-dependent protein kinase 5; CBP60g, calcium-sensing protein $60 \mathrm{~g}$.

conferring resistance to $X c c$, which suggested that quantitative disease resistance to $X c c$ is governed by a complex network by interconnecting multiple response pathways induced by distinct pathogen molecular determinants (Debieu et al., 2016).

Secondary metabolites like glucosinolates (GSLs) are also involved in quantitative resistance against $X c c$ in B. oleracea (Iglesias-Bernabé et al., 2019). B. oleracea is known for its high content of GSLs whose hydrolysed products have been proven toxic to pathogens. GSLs play an important role in plant defence against $X c c$, and many workers have described the potential role of GSL in defence against Xcc in B. oleracea and related Brassica species (Aires et al., 2011; Velasco et al., 2013; Madloo et al., 2019; Rubel et al., 2020) which will be discussed later. While dissecting the quantitative resistance against race 1 of Xcc, multi-trait QTL analysis identified four QTLs of resistance and the spread of Xcc was found related to the size of the leaf (Iglesias-Bernabé et al., 2019). The mechanism of resistance was found to be related with the synthesis of GSLs and phenolics.
However, quantitative resistance governed by minor-effect QTL are difficult to exploit than the major R-genes. In the post-genomic era, improved tools and methods are becoming handy to better integrate the quantitative resistance into plant breeding techniques. In the best scenario, combining major R-genes with quantitative resistance could be proved as an interesting strategy for effective breeding to confer durable resistance to Xcc in B. oleracea.

\section{Transcriptomics}

Transcriptomics refers to the study of the entire set of RNA of an organism, including mRNAs and other noncoding RNAs (McGettigan, 2013). Transcriptome study helps in characterizing and quantifying the entire RNA present in an organ, tissue, or cell in a given organism. Different genes of a cell are up or downregulated in different physiological and developmental process. So, comparing of RNA expression profile provides an insight into when and where the genes are 
expressed under different treatments and helps in validation of the putatively differentially expressed genes. This, in turn, helps in the identification of candidate genes influencing any important traits involved in the cellular process of an organism. Transcriptome is highly dynamic unlike the genome which basically remains constant irrespective of age, organ, or growth conditions (El-Metwally et al., 2014). RNA-seq has largely replaced the earlier commonly used approaches for gene expression profiling such as microarray and serial analysis of gene expression (SAGE). Transcriptome analysis reveals the molecular mechanisms underlying specific biological processes and pathogenesis, providing new guidance in disease control and crop improvement (Kell and Oliver, 2016). Additionally, transcriptome studies decipher many dynamic changes occurring in molecular communication during the plant infection by the pathogens. The recent advancement of NGS technologies have allowed the transcriptome sequencing through cDNA sequencing on a massive scale (Voelkerding et al., 2010). This has permitted the researchers to design large-scale experiments to capture and enumerate the transcripts and analyse the transcriptional responses of $B$. oleracea to black rot infection which revealed the role of different genes involved in $B$. oleracea-Xcc interaction (Tables 2, 3).

Over the years, transcriptome analysis has been used to understand the plant-microbe interactions (Wulf et al., 2003). Gene regulation studies in response to pathogen attack may indicate the role of the relevant defence genes (Singh et al., 2018). Suppression subtractive hybridisation (SSH) is regarded as a powerful approach for identification of differentially expressed genes including the response of the plants to pathogen infection (Jin et al., 2010; Luo et al., 2010; Yue et al., 2010) which could help in the global analysis of gene expression. SSH does not require sequence information to study differential genes (Kathju et al., 2006) and is often used to identify the genes responding to pathogens and stresses in plants (Xiong et al., 2001). So, Jiang et al. (2011) attempted to understand the

TABLE 2 | Published transcriptomic studies in Brassica species on black rot resistance.

\begin{tabular}{|c|c|c|c|c|c|c|}
\hline Species & $\begin{array}{l}\text { Plant } \\
\text { organ }\end{array}$ & $\begin{array}{l}\text { Time point } \\
\text { (Tissue } \\
\text { collection) }\end{array}$ & Methodology & Objective & Inference & References \\
\hline $\begin{array}{l}\text { Brassica } \\
\text { oleracea } \\
\text { var. } \\
\text { capitata }\end{array}$ & Leaves & - & RNA-Seq & $\begin{array}{l}\text { Identification of ESTs related to } \\
\text { the NBS-LRR domain in the } \\
\text { black-rot resistant line C1234 }\end{array}$ & $\begin{array}{l}29 \text { ESTs containing NBS-LRR domains were } \\
\text { identified in the black rot resistant cabbage line } \\
\text { C1234, among which } 22 \text { were TIR-NBS-LRRs } \\
\text { and } 7 \text { were CC-NBS-LLRs type }\end{array}$ & $\begin{array}{l}\text { Izzah et al., } \\
2014\end{array}$ \\
\hline $\begin{array}{l}\text { Brassica } \\
\text { oleracea }\end{array}$ & Leaves & $\begin{array}{l}\text { 3- and 12-days } \\
\text { post- } \\
\text { inoculation } \\
\text { (dpi) }\end{array}$ & RNA-Seq & $\begin{array}{l}\text { Investigation of molecular } \\
\text { changes produced in } \\
\text { B. oleracea plants infected by } \\
X_{C C}\end{array}$ & $\begin{array}{l}\text { Genes related to terpenes, flavonoids, alkaloids } \\
\text { and anthocyanins and phytohormones were } \\
\text { up-regulated at early stage of infection }\end{array}$ & $\begin{array}{l}\text { Tortosa } \\
\text { et al., } 2018 a\end{array}$ \\
\hline $\begin{array}{l}\text { Brassica } \\
\text { oleracea } \\
\text { var. } \\
\text { capitata }\end{array}$ & $\begin{array}{l}\text { Leaves, } \\
\text { root, } \\
\text { silique, and } \\
\text { stem }\end{array}$ & - & RNA-Seq & $\begin{array}{l}\text { To identify NBS-encoding } \\
\text { genes linked to black rot } \\
\text { resistance in cabbage }\end{array}$ & $\begin{array}{l}31 \text { NBS- genes encoding TIR, NBS, LRR and } \\
\text { RPW8 protein domains were differentially } \\
\text { expressed in leaves, root, silique and stem } \\
\text { tissues of cabbage. Several of these genes } \\
\text { were highly expressed in resistant compared to } \\
\text { susceptible cabbage lines. }\end{array}$ & $\begin{array}{l}\text { Afrin et al., } \\
2018 b\end{array}$ \\
\hline $\begin{array}{l}\text { Brassica } \\
\text { oleracea } \\
\text { var. italica }\end{array}$ & Leaves & $\begin{array}{l}\text { 3- and 12-days } \\
\text { post inoculation } \\
\text { (dpi) }\end{array}$ & RNA-Seq & $\begin{array}{l}\text { To investigate the transcriptome } \\
\text { dynamics of Brassica oleracea } \\
\text { in response to Xcc race } 1\end{array}$ & $\begin{array}{l}\text { Two calcium-signalling proteins (CBP60g and } \\
\text { SARD1) regulated the plant transcriptomic } \\
\text { response in the resistance against XCc which } \\
\text { was confirmed using Arabidopsis knockout } \\
\text { mutants }\end{array}$ & $\begin{array}{l}\text { Tortosa } \\
\text { et al., } 2019\end{array}$ \\
\hline $\begin{array}{l}\text { Brassica } \\
\text { oleracea } \\
\text { var. } \\
\text { capitata }\end{array}$ & Leaves & $\begin{array}{l}0 \text { - and 6-days } \\
\text { after } X_{C C} \\
\text { inoculation }\end{array}$ & RNA-Seq & $\begin{array}{l}\text { Genome-wide identification, } \\
\text { expression profile of the TIFY } \\
\text { gene family in } B \text {. oleracea var. } \\
\text { capitata, and their response to } \\
\text { various pathogen infections } \\
\text { including } X_{C C}\end{array}$ & $\begin{array}{l}36 \text { TIFY genes were identified including } 22 \text { JAZ } \\
\text { genes and the JAZs were induced and inhibited } \\
\text { after XCC infection in the resistance line, } \\
\text { indicating their probably distinct roles in disease } \\
\text { resistance or susceptibility. }\end{array}$ & $\begin{array}{l}\text { Liu et al., } \\
2020\end{array}$ \\
\hline $\begin{array}{l}\text { Brassica } \\
\text { oleracea }\end{array}$ & Leaves & $\begin{array}{l}0-, 12-, 24-, \\
48-\text { and } 96-\mathrm{h} \\
\text { post- } \\
\text { inoculation } \\
\text { (hpi) }\end{array}$ & RNA-Seq & $\begin{array}{l}\text { Transcriptome analysis of } \\
\text { resistant and susceptible lines } \\
\text { of } B \text {. oleracea in response to } \\
\text { early infection with } X_{C C}\end{array}$ & $\begin{array}{l}\text { Genes related to glucosinolate biosynthesis and } \\
\text { catabolic pathways, ROS scavenging, } \\
\text { photosynthetic energy metabolism, hormonal } \\
\text { receptor-kinase-related genes and } \\
\text { NBS-encoding resistance genes were } \\
\text { enhanced during the early infection period. }\end{array}$ & $\begin{array}{l}\text { Sun et al., } \\
2020\end{array}$ \\
\hline $\begin{array}{l}\text { Brassica } \\
\text { oleracea } \\
\text { var. } \\
\text { capitata }\end{array}$ & Leaves & $\begin{array}{l}\text { 3-days after } \\
\text { inoculation }\end{array}$ & RNA-Seq & $\begin{array}{l}\text { Transcriptomic analysis of } \\
\text { resistant and susceptible } \\
\text { cabbage lines to decipher the } \\
\text { molecular bases and } \\
\text { mechanisms of early-phase } \\
\text { response against black rot }\end{array}$ & $\begin{array}{l}\text { Top ten differential expression genes were } \\
\text { found to contain NBS-LRR genes, protein } \\
\text { kinase genes and expansin genes indicating } \\
\text { some genes playing key roles in the regulation } \\
\text { of early response to black rot infection. }\end{array}$ & $\begin{array}{l}\text { Song et al., } \\
2020\end{array}$ \\
\hline
\end{tabular}


TABLE 3 | List of differential gene expression studies in Brassica species on black rot resistance.

\begin{tabular}{|c|c|c|c|c|c|}
\hline Species & $\begin{array}{l}\text { Plant } \\
\text { organ }\end{array}$ & $\begin{array}{l}\text { Time point (Tissue } \\
\text { collection) }\end{array}$ & Objective & Inference & References \\
\hline $\begin{array}{l}\text { Brassica } \\
\text { oleracea var. } \\
\text { botrytis }\end{array}$ & Leaves & - & $\begin{array}{l}\text { Cloning of differentially expressed } \\
\text { fragments in cauliflower after } X_{C C} \\
\text { inoculation }\end{array}$ & $\begin{array}{l}\text { M6 gene fragment was identified as a new } \mathrm{H}_{2} \mathrm{O}_{2} \text { downstream defence related gene } \\
\text { fragment which could be induced by } X_{C C} \text { and } \mathrm{H}_{2} \mathrm{O}_{2} \text {. }\end{array}$ & $\begin{array}{l}\text { Gu et al., } \\
2008\end{array}$ \\
\hline $\begin{array}{l}\text { Brassica } \\
\text { oleracea } \\
\text { var. botrytis }\end{array}$ & Leaves & $\begin{array}{l}0-, \text { 2-, 6-, 12-, 24-, 48-, } \\
\text { 72-, and } 96-\mathrm{h} \text { post- } \\
\text { infection }\end{array}$ & $\begin{array}{l}\text { Identification of differentially expressed } \\
\text { genes associated with resistance to } X_{C C} \text { in } \\
\text { cauliflower }\end{array}$ & $\begin{array}{l}\text { Gene expression of } 12 \text { genes corresponding to a range of functional categories } \\
\text { including metabolism, photosynthesis as well as cell defense (plant defensin gene } \\
P D F 1.2 \text {, lipid transfer protein, thioredoxin } \mathrm{h} \text { ) in response to XCC was quicker and more } \\
\text { intense in cauliflower resistant line } \mathrm{C} 712 \text { suggesting their involvement in the response } \\
\text { against } X_{C C} \text { infection. }\end{array}$ & $\begin{array}{l}\text { Jiang et al., } \\
2011\end{array}$ \\
\hline $\begin{array}{l}\text { Brassica } \\
\text { oleracea var. } \\
\text { capitata }\end{array}$ & Leaves & $\begin{array}{l}\text { 12-, 24-, and } 48-\mathrm{h} \text { post- } \\
\text { inoculation }\end{array}$ & $\begin{array}{l}\text { To identify genes involved in resistance } \\
\text { mechanisms against } X_{C C} \text { in cabbage }\end{array}$ & $\begin{array}{l}\text { A total of } 150 \text { unigenes obtained were classified into five major functional categories: } \\
\text { metabolism, disease and defence-related, structural proteins, signalling pathway related } \\
\text { and unclassified group. The defence-specific genes showed increased expression in the } \\
\text { resistant cultivar and elicited a strong hypersensitive response upon attack by black rot. }\end{array}$ & $\begin{array}{l}\text { Roohie and } \\
\text { Umesha, } \\
2015\end{array}$ \\
\hline $\begin{array}{l}\text { Brassica rapa } \\
\text { var. glabra }\end{array}$ & Leaves & $\begin{array}{l}\text { 1-, 2-, 3-days } \\
\text { post-inoculation (dpi) }\end{array}$ & $\begin{array}{l}\text { Differential defence responses of } \\
\text { susceptible and resistant kimchi cabbage } \\
\text { cultivars to black rot }\end{array}$ & $\begin{array}{l}\text { PR1, BGL2, Chi1, PR4, VSP2, LOX2 and GST1 were differentially regulated in the } \\
\text { kimchi cabbage leaves during resistance reaction and the resistance was strongly } \\
\text { associated with the hormone dependent transcriptional induction of defence genes. }\end{array}$ & $\begin{array}{l}\text { Lee and } \\
\text { Hong, } 2015\end{array}$ \\
\hline $\begin{array}{l}\text { Brassica } \\
\text { oleracea }\end{array}$ & Leaves & $24 \mathrm{~h}$ after inoculation & $\begin{array}{l}\text { Role of microRNAs (miRNAs) } \\
\text { in B. oleracea resistance against } X_{C C}\end{array}$ & $\begin{array}{l}\text { The decreased expression of miR156, miR169 and miR390 may be involved in a } \\
\text { stress-induced flowering phenomenon due to XCC infection. miR167, as miR390, } \\
\text { modulates the expression of auxin response factors (ARFs) and may be involved in a } \\
\text { PAMP-triggered immunity response. The upregulation of the } 4 \text { miRNAs could play a role } \\
\text { in B. oleracea resistance enhancement against XcC. }\end{array}$ & $\begin{array}{l}\text { Santos L.S. } \\
\text { et al., } 2019\end{array}$ \\
\hline Brassica napus & Leaves & 14-days post- inoculation & $\begin{array}{l}\text { To elucidate the cultivar variation in disease } \\
\text { susceptibility and disease responses in } \\
\text { relation to hormonal status in the interaction } \\
\text { of Brassica napus cultivars and } X_{C C}\end{array}$ & $\begin{array}{l}\text { The ratios of ABA JA and SA/JA increased with enhanced expression of SA signalling } \\
\text { regulatory gene (NPR1) and transcriptional factor (TGA1) with antagonistic suppression } \\
\text { of JA- regulated gene PDF 1.2. In the resistant cultivar, defensive metabolites } \\
\text { accumulated with the enhanced expression of genes involved in flavonoids (chalcone } \\
\text { synthase), proanthocyanidins (anthocyanidin reductase), and hydroxycinnamic acids } \\
\text { (ferulate-5-hydroxylase) biosynthesis and higher redox status were observed, whereas } \\
\text { the opposite results were obtained for susceptible cultivars. }\end{array}$ & $\begin{array}{l}\text { Islam M.T. } \\
\text { et al., } 2017\end{array}$ \\
\hline Brassica napus & Leaves & $\begin{array}{l}\text { 14-days post- } \\
\text { inoculation }\end{array}$ & $\begin{array}{l}\text { To investigate the hormonal regulations in } \\
\text { soluble and cell wall-bound phenolic } \\
\text { compound accumulation in the resistant } \\
\text { and susceptible cultivar of Brassica napus }\end{array}$ & $\begin{array}{l}\text { Enhanced expression of JA signalling was concurrently based on transcriptional } \\
\text { up-regulation of } P A P 1, M Y B \text { transcription factor, and phenylpropanoid biosynthesis } \\
\text { genes (CHS, F5H, COMT1, and CAD2) which induced the higher accumulation of } \\
\text { defensive metabolites such as hydroxycinnamic acids and flavonoids in the resistant } \\
\text { cultivar. }\end{array}$ & $\begin{array}{l}\text { Islam et al., } \\
2019 b\end{array}$ \\
\hline $\begin{array}{l}\text { Brassica } \\
\text { oleracea var. } \\
\text { capitata }\end{array}$ & Leaves & $\begin{array}{l}\text { 1-, 3-, and 5-days after } \\
\text { inoculation (DAl) }\end{array}$ & $\begin{array}{l}\text { To understand the role of glucosinolate } \\
\text { biosynthesis and breakdown-related genes } \\
\text { for resistance against } X c c \text { in cabbage }\end{array}$ & $\begin{array}{l}\text { Positive and significant association between aliphatic GSL compounds and expression } \\
\text { values of transcription factor and GSL biosynthesis-related genes (ST5C-Bol030757 } \\
\text { and AOP2-Bo9g006240) as well as between indolic GSL compounds and the } \\
\text { expression of transcription factor and GSL biosynthesis-related genes } \\
\text { (MYB34-Bol017062, MYB122-Bol026204, CYP81F2-Bol012237, CYP81F4-Bol032712 } \\
\text { and CYP81F4-Bo/O32714) were reported. }\end{array}$ & $\begin{array}{l}\text { Rubel et al., } \\
2020\end{array}$ \\
\hline Brassica napus & Leaves & $\begin{array}{l}\text { 14-days post- inoculation } \\
\text { (DPI) }\end{array}$ & $\begin{array}{l}\text { To investigate the involvement of } \\
\text { R-gene-mediated calcium signalling and } \\
\text { hormonal signalling in Effector-triggered } \\
\text { immunity (ETI) or susceptibility in the } \\
\text { XCC-B. napus pathosystem }\end{array}$ & $\begin{array}{l}\text { In the resistance interaction (ETI), R-gene (ZAR1) and related genes (NDR1, MAPK6), } \\
\text { SA receptor, (NPR3 and NPR4), JA synthesis (LOX2) and signalling (PDF1.2) genes } \\
\text { were up-regulated while calcium signalling-related genes (Ca2CATPase, CDPK5, } \\
\text { CBP60g) were down-regulated. In the susceptible interaction, R-gene (TAO1), SA } \\
\text { synthesis (ICS1) and signalling (NPR1), calcium-signalling-related genes (Ca2CATPase, } \\
\text { CDPK5, CBP60g), SA synthesis (ICS1) genes were up-regulated whereas JA synthesis } \\
\text { (LOX2) and resistance related gene (MAPK6) were down-regulated. }\end{array}$ & $\begin{array}{l}\text { Mamun } \\
\text { et al., } 2020\end{array}$ \\
\hline
\end{tabular}


molecular mechanisms of resistance of cauliflower in response to Xcc infection combining SSH with RT-PCR. An SSH cDNA library comprising many defence-related genes including plant defensin gene $P D F 1.2$, lipid transfer protein, thioredoxin h., etc. was established and 12 differentially expressed genes associated with Xcc resistance were identified. Roohie and Umesha (2015) also employed the SSH technique to identify the genes involved in black rot resistance mechanisms in B. oleracea var. capitata. Out of 150 unigenes (classified in to five functional categories), $35 \%$ of the unigenes accounted for the defence-related unigenes. Defence-specific representation of the genes was confirmed by semi-quantitative RT-PCR and its increased expression in the resistant cultivar was validated by qPCR.

Several researchers have reported the differential responses of genes in the susceptible and resistant cultivars of B. oleracea to black rot disease (Table 3). Cloning of differentially expressed cDNA fragments obtained from black rot resistant cauliflower plants revealed that $\mathrm{M} 6$ gene fragment was a new $\mathrm{H}_{2} \mathrm{O}_{2}$ downstream defence-related gene fragment and could be induced during infection by $X c c$ (Gu et al., 2008). Transcriptomic analysis of the leaves of $B$. oleracea collected 3 and 12 dpi revealed the upregulation of 78 and 809 genes and a downregulation of 10 and 169 genes in the early and late responses, respectively (Tortosa et al., 2018a). During Xcc attack, genes related with terpenes, flavonoids, alkaloids, anthocyanins, SA, ethylene, and JA were upregulated in early response exhibiting their importance during pathogenesis. To analyse the dynamics of the transcriptional response of B. oleracea plants infected with $X c c$, Tortosa et al. (2019) highlighted the role of $\mathrm{Ca}^{+2}$ signalling proteins as secondary messenger for several downstream signalling processes which include the activation of several transcription factors involved in the SA-mediated host defence in $B$. oleracea. Two calcium-signalling proteins $(C B P 60 g$ and $S A R D 1)$ played important roles in resistance against $X c c$ which was, again, confirmed by Arabidopsis knockout mutants. In another study, Lee and Hong (2015) analysed the pathogenesis-related (PR) gene expression during resistance and susceptible responses to black rot disease in kimchi cabbage. The semi-quantitative RT-PCR analysis revealed the transcriptional activation of PR1, BGL2, Chi1, PR4, VSP2, LOX2, and GST1 in the leaves of resistant genotypes as compared to susceptible genotypes. Also, the PR genes were found to be regulated by defencerelated hormones such as SA, JA, and ethylene. The results indicated that differential defence signalling crosstalk and PR gene expression are involved in cultivar specific resistance against several fungal diseases including black rot in kimchi cabbage and, importantly, the resistance was strongly associated with the hormone-dependent transcriptional induction of defence genes. Jasmonate and other related signalling compounds are involved in the host immunity of plants (Thines et al., 2007; Melotto et al., 2008). A B. oleracea LOX gene was cloned in cabbage which was involved in jasmonic acid biosynthesis, and the quantification of transcript levels showed that BoLOX transcripts were accumulated rapidly after various biotic stresses (Zheng et al., 2007). The JASMONATE ZIM-DOMAIN (JAZ) proteins are the key repressors of jasmonate (JA) signalling and plays key role in plant defence responses (Chini et al., 2007; Thatcher et al.,
2016). To investigate the expression difference of cabbage JAZ genes after infection with $X c c$, RNA-seq data of both resistant and susceptible materials were analysed by Liu et al. (2020) and many JAZ genes were found to be up-regulated in both the resistance and susceptible lines.

For better resistance against $X c c$, it is essential to understand the infection and multiplication process of Xcc in host cells, and tremendous progress have been made in this direction with the identification and characterisation of more than 100 genes contributing to Xcc virulence (Chan and Goodwin, 1999; He et al., 2007; He and Zhang, 2008; Büttner and Bonas, 2010). Liao et al. (2016) investigated the potential role of prc gene in the pathogenicity of the black rot and the transcriptional profiling of the wild type and mutant showed that the mutation of prc in Xcc leads to the alteration of the transcription level of 91 genes. The genes were associated with a range of biological functions such as carbohydrate transport and metabolism, cell wall/membrane biogenesis, post-translational modification, protein turnover and chaperones, inorganic ion transport, metabolism, and signal transduction mechanisms, providing new information about the regulatory role of prc gene. Micro RNAs (miRNAs) are known to be associated with various biological processes including abiotic and biotic stresses (Rubio-Somoza et al., 2009; Kruszka et al., 2012). miRNAs are conserved and are involved in many molecular interaction networks including plant-pathogen interactions (Sunkar et al., 2012; Islam W. et al., 2017). The role of miRNAs in plants was examined in response to Xcc infection and four miRNAs (miR156, miR167, miR169, and miR390) were found to be differentially expressed showing a down and up-regulated expression profile in the susceptible and resistant cultivars, respectively (Santos L.S. et al., 2019). This suggested the possible role of miRNAs in enhancing the resistance of $B$. oleracea against $X c c$ and could be used as potential resistance markers for B. oleracea-Xcc interaction. Understanding the early response to black rot holds the key to control black rot and reduce the crop losses. To understand the molecular basis of early-phase response of different resistant cabbage lines against black rot infection, a comprehensive transcriptome analysis of resistant and susceptible lines identified 10,030 differentially expressed genes (Song et al., 2020). Three hundred and eighty four differentially expressed genes overlapped in the susceptible and resistant cabbage lines and the top ten genes contained NBS-LRR type, protein kinase, and expansin genes, indicating their role in early response to black rot infection. Again, transcriptome analysis of the leaves of Xcc-resistant (QP07) and susceptible (DBP71) lines was carried out to understand the early defence response (Sun et al., 2020). A total of 3,357 up and 4,091 down-regulated genes were identified between QP07 and DBP71 and functional annotation pathway analysis indicated the enhancement of the ROS scavenging, glucosinolate biosynthesis and catabolic pathways, hormonal, receptor kinase-related genes, and (NBS)-encoding R-genes during the early infection period. Furthermore, photosynthetic energy metabolism was found to be actively regulated by the host plant in response to Xcc infection. Glucosinolates (GSLs) play important roles in plant defence mechanisms against necrotrophs, biotrophs, and hemibiotrophs and are broadly found in different Brassica species. However, 
the information about GSL-mediated resistance mechanisms and GSL biosynthesis and catalysis related gene expression after black rot infection is limited. In a recent study, Rubel et al. (2020) found positive and significant association between the aliphatic and indolic GSL compounds with the expression values of transcription factor and GSL biosynthesis-related genes in cabbage. The phytohormones, SA and JA, are the central regulators in hormonal signalling pathways to induce defence response against the pathogens by inducing the genes related to phenylpropanoid synthesis pathway which produces an array of defensive metabolites and these genes were differentially expressed for $X c c$ resistance and susceptibility in Brassica species. Islam et al. (2019b) demonstrated that the enhanced expression of JA signalling was concurrently based on transcriptional up-regulation of $P A P 1$, MYB transcription factor, and phenylpropanoid biosynthetic genes (CHS, F5H, COMT1, $C A D 2)$ which induced the higher accumulation of defensive metabolites such as hydroxycinnamic acids and flavonoids in the resistant cultivar (cv. Capitol). Another study reported the differential expression of the NBS-LRR encoding R-genes (ZAR1 and TAO1) and related genes (MAPK6), calcium signallingrelated genes (Ca2+ATPase, CDPK5, CBP60g, CAS, CaM), SA receptor (NPR3, NPR4), synthesis and signalling (ICS1, NPR1) genes, JA synthesis (LOX2), and signalling ( $P D F$ 1.2) genes in the contrasting genotypes of $B$. napus which indicated that JA induced an antagonistic depression of SA suggesting the proper maintenance of SA/JA ratio as a part of the resistance mechanisms against Xcc (Mamun et al., 2020), also proved by Islam M.T. et al. (2017).

Taken together, it could be inferred that genes related to photosynthesis, glucosinolate biosynthesis and catabolism, phenylpropanoid biosynthesis, ROS scavenging, calcium signalling, hormonal signalling and synthesis pathway, receptorkinase-related genes, and NBS-encoding resistance genes were differentially expressed upon Xcc infection. The examination pattern of hormone-related DEGs revealed that instead of SA signalling pathway, JA signalling pathway may play a critical role in host resistance to hemibiotrophic pathogen such as Xcc. The up-regulation of the genes involved in glucosinolate biosynthesis and catabolic processes during early infection confirmed the role of glucosinolate hydrolytic products in the defence of Brassica species against Xcc. The enhancement of resistance to Xcc by GSLs has been confirmed by several proteomic and metabolomic studies. Several transcriptome studies have revealed the NBS-LLR encoded resistance genes as the key regulators involved in black rot resistance in Brassica species. Also, the transcriptome studies revealed that photosynthesis is playing a major role in the interaction between Xcc and Brassica species. Down-regulation of the DEGs involved in photosynthesis in the resistant plants and up-regulation in susceptible plants suggested that the susceptible plants require more energy to cope up with the infection by Xcc. In contrast, by reducing the photosynthetic metabolism, the resistant plants try to control the energy supply of $X c c$, thereby inhibiting its growth. This also shows the greater resilience of the resistant plants in restoring the normal photosynthetic metabolism compared with the susceptible plants. Upon pathogen attack, rapid production of reactive oxygen species (ROS) leading to oxidative burst is described as one of the earliest responses of the host to pathogen infection onsetting the hypersensitive response. However, to adapt to ROS toxicity, the enzymatic and non-enzymatic antioxidants are activated to scavenge the ROS and reduce the oxidative stress which is part of the resistance mechanisms. The up-regulation of the ROS scavenging enzymes such as catalase, superoxide dismutase, glutathione peroxidase 5 , and several glutathione S-transferases in the resistant plants indicated that balancing of host oxidative stress response is essential to efficiently control Xcc.

\section{Proteomics}

Proteomics is the high-throughput study of total proteins expressed in a particular organism, organ, specific tissue, and cell of an individual in a given time or developmental stage. Proteomics deals with the analysis of protein-protein interactions, protein expression profiles, protein trafficking, localisation, and their various roles in different cellular processes. Unlike the genome of an organism which is relatively fixed, the proteome is highly dynamic similar to transcriptome and changes based on temporal or environmental factors. There are many proteins present in an organism and its presence is dependent on several factors, including the response to abiotic and biotic stress (Renaut et al., 2006). Proteomics is regarded as a tool for functional genomics in plants and serve to analyse major signalling and biochemical pathways and complex responses of plants to environmental stimuli (Setia and Setia, 2008). Protein is the final executors of most of the biological processes translating plethora of genomic information into functional information. Proteomics could be very informative while studying the plant stress response and tolerance either in a genome-wide or samplescale (Nakagami et al., 2012). Post-transcriptional modifications such as proteolysis, glycosylation, phosphorylation, nitrosylation, and ubiquitination mediate the functions of a large fraction of proteins (Mann and Jensen, 2003; Beck et al., 2006) playing a key role in intracellular signalling, controlling of enzyme activity, protein turnover, transport, cell structure integrity (Wu et al., 2011), and also to understand the molecular mechanisms of plant-pathogen interactions (Quirino et al., 2010; Lodha et al., 2013). Quantitative proteomics could reveal the differentially expressed proteins contributing to stress response process as well (Liu et al., 2015).

Several powerful techniques are used to identify and quantify proteins of complex biological samples. The most widely used methods during high-throughput protein analysis are gel-based techniques (Chevalier, 2010). The quantitative measurement of proteins can be performed using SDS-PAGE, but for identification and characterisation of the separated proteins, twodimensional polyacrylamide gel electrophoresis (2DPAGE or 2$\mathrm{DE}$ ) and mass spectrometry (MS) is required (Eldakak et al., 2013). 2-DE has become the most versatile tool for protein separation as it resolves the proteins based on both isoelectric point (separated according to their $\mathrm{pI}$ in $\mathrm{pH}$ gradient PAGE) and molecular mass (SDS PAGE, separated according to molecular weight) (Pomastowski and Buszewski, 2014). However, some disadvantages such as labour intensiveness, low reproducibility, 
insensitiveness to low-copy number proteins, etc. (Eldakak et al., 2013) have hampered the utility of this method. A modified version of 2-DE, difference gel electrophoresis (2D-DIGE), circumvents most of these issues which can control gel-togel variation, allows multiple samples to be co-separated, and enhance the reproducibility (Beckett, 2012). Currently, mass spectrometry (MS) is the most commonly used technique for proteome analysis (Aebersold and Mann, 2003). Before MS analysis, the pre-separation of complex protein mixtures is done by 2 -DE and cleaved into smaller peptides. Different types of MS methods have enhanced automation in proteome analysis and have replaced the gel-based separation techniques of peptides. Mass spectroscopy includes several approaches such as liquid chromatography-mass spectrometry (LC-MS/ MS), ion trap-mass spectrometry (IT-MS), and matrix-assisted laser desorption/ ionisation-mass spectrometry (MALDI-MS), etc. (Helmy et al., 2011, 2012; Komatsu et al., 2014; Shao et al., 2015).

Comparative proteome analysis may help in understanding different biotic stresses in B. oleracea as the language of plantpathogen lies in the proteins. After the first proteome analysis carried out in the model plants Arabidopsis thaliana (Kamo et al., 1995) and rice (Komatsu and Tanaka, 2005), several advances were made in proteomics to answer the complex biological questions. In $B$. oleracea, proteomic approach was used to understand the mechanisms of interaction of black rot with the host plants (Table 4). Andrade et al. (2008) employed in vivo proteome analysis for protein expression characterisation of Xcc in close interaction with B. oleracea and showed that in vivo expression method originally developed for Xanthomonas axonopodis pv. citri can be successfully employed for $X c c$. So, for the first time, in vivo global proteome analysis of $X c c$ was carried out and the protein profiles of $X c c$ was compared during the interactions with resistant and susceptible cultivars of B. oleracea (Villeth et al., 2009). The results obtained revealed a group of proteins exclusive to the resistance interaction. Interestingly, different isoforms of the same protein were found in the resistance and susceptible interactions, indicating the same protein playing different roles depending on the types of interaction. The authors also observed the up-regulation of proteins involved in photosynthesis during the resistance interaction.

To identify the proteins involved in pathogenicity, the interaction of $X c c-B$. oleracea was studied using an in vivo system in three conditions using the label free shotgun $2 \mathrm{D}$ nanoUPLC/MSE (Santos et al., 2017). A model for Xccsusceptible host interaction was proposed, which showed that Xcc increases the abundance of proteins required for pathogenicity and cell protection. Pathogenicity related proteins such as acetylornithine $(\mathrm{ArgD})$ and several defence and stress-related proteins (lipoxygenase, annexins, apocitocrome $\mathrm{f}$, antimicrobial compound phytoalexin) was observed in the susceptible (REK) and resistant (REU) Brassica plants, respectively. Also, proteins associated with photosystems were identified in the resistant plants. Importantly, the confirmation of the differential expression of the selected genes indicated that these genes, directly or indirectly, are involved in the Xcc colonisation of the host plant which could be used as future targets for knock-out studies to confirm their role in the pathogenicity. Identification of proteins expressed during plant-pathogen interactions to know which proteins confer disease resistance is essential to understand the plant-pathogen interactions. A novel peroxidase isozyme and lignification in hydathodes were involved in resistance to black rot disease in cabbage (Gay and Tuzun, 2000). Costa et al. (2014) identified 22 differential proteins during early infection by Xcc in B. oleracea. One of the proteins identified was precursor of peroxiredoxin which was decreased in the susceptible genotype, and proteins involved in the photosynthesis were also found to be modulated by $X c c$ infection which may help in better understanding of the B. oleracea-Xcc interaction.

A study by Vega-Álvarez et al. (2021) has shown that Xcc infection reduces biomass and photosynthesis in the aerial parts of the seedlings though no effect was detected on the leaves or the biomass of the inoculated adult plants of B. oleracea. The biochemical studies state that stomatal closure happens in the presence of $X c c$ (Ho et al., 2013). Abscisic acid (ABA) is a signalling molecule which can suppress the plant immune response. It has been shown that increased abundance of proteins involved with ABA may favour susceptibility (Kim et al., 2011; Desclos-Theveniau et al., 2012). The ABA signalling pathway is manipulated by a type III effector (AvrXccC8004) of Xcc, thereby increasing the ABA levels (Ho et al., 2013) and proteins responsive to ABA (Santos C. et al., 2019) during the infection by Xcc. ABA along with ROS and elicitors of plant defence may stimulate $\mathrm{Ca}^{2+}$ influx (Tortosa et al., 2019) which may increase $\mathrm{Ca}^{2+}$ in guard cells prompting stomatal closure (Klüsener et al., 2002). So, stomata can work as part of the innate immunity of a plant by preventing Xcc entry (Gudesblat et al., 2009).

$X c c$ infection promotes changes in the secondary and primary metabolism in the host to induce defence programs affecting growth and development (Vega-Álvarez et al., 2021). The changes mostly include down-regulation of proteins involved in photosynthesis (Ribeiro et al., 2018; Santos C. et al., 2019). An earlier study (Villeth et al., 2016) had shown a clear reduction in the abundance of proteins involved in energetic metabolism in susceptible interaction with an opposite behaviour in the resistance interaction. This study indicated that resistance to black rot in B. oleracea is correlated with the ability of the plants to keep sufficient photosynthesis metabolism activity to provide energy supplies necessary for an active defence. This was also reported by Villeth et al. (2009). Later, detailed studies of photosynthesis-related proteins upon Xcc attack in Brassica spp. divulged the down-regulation of these proteins in the resistance reactions. Ribeiro et al. (2018) reported the reduction of photosynthesis-related proteins in the susceptible plants of B. oleracea at an early stage of infection with Xcc. Also, decreased abundance of ubiquitin (to stop the bacteria from using ubiquitination pathway) and malate dehydrogenase (to reduce energy metabolism in the early stage of infection) were found, playing important roles in the resistance mechanisms against Xcc. Proteome analysis of Xccinfected young cabbage leaves and chloroplast-enriched samples of both the susceptible and resistant cultivars revealed the differential abundance of photosynthesis-related proteins in both resistance and susceptible interactions (Santos C. et al., 2019). As 
TABLE 4 | Published proteomic analyses in Brassica species during interaction with black rot.

\begin{tabular}{|c|c|c|c|c|c|c|}
\hline Species & $\begin{array}{l}\text { Plant } \\
\text { organ }\end{array}$ & $\begin{array}{l}\text { Time point } \\
\text { (Tissue } \\
\text { collection) }\end{array}$ & Methodology & Objective & Inference & References \\
\hline $\begin{array}{l}\text { Brassica } \\
\text { oleracea var. } \\
\text { capitata }\end{array}$ & Leaves & $\begin{array}{l}\text { 24-h after } \\
\text { inoculation } \\
\text { (hai) }\end{array}$ & 2-DE & $\begin{array}{l}\text { To identify the Brassica } \\
\text { oleracea proteins during } \\
\text { early infection by Xcc }\end{array}$ & $\begin{array}{l}\text { Peroxiredoxin precursor protein decreased in the } \\
\text { susceptible genotype inoculated with } X_{c c} \text {. Proteins } \\
\text { involved in photosynthesis were also modulated by } \\
\text { Xcc infection. }\end{array}$ & $\begin{array}{l}\text { Costa et al., } \\
2014\end{array}$ \\
\hline $\begin{array}{l}\text { Brassica } \\
\text { oleracea }\end{array}$ & Leaves & $\begin{array}{l}\text { 5-, } 10-\text {, and } \\
15-\text { days after } \\
\text { inoculation } \\
\text { (DAl) }\end{array}$ & $\begin{array}{l}\text { 2-DE, } \\
\text { MALDI-TOF }\end{array}$ & $\begin{array}{l}\text { To identify the proteins in } \\
\text { susceptible and resistant } \\
\text { Brassica oleracea in } \\
\text { response to } X_{c c} \text { infection }\end{array}$ & $\begin{array}{l}\text { Susceptible interaction showed a clear reduction in } \\
\text { the abundance of proteins involved in energy } \\
\text { metabolism and defence whereas in the resistance } \\
\text { interaction, these proteins showed an opposite } \\
\text { behavior. Resistance was correlated with the ability } \\
\text { of the plants to keep sufficient photosynthesis } \\
\text { metabolism activity to provide energy supplies } \\
\text { necessary for an active defence. }\end{array}$ & $\begin{array}{l}\text { Villeth et al., } \\
2016\end{array}$ \\
\hline $\begin{array}{l}\text { Brassica } \\
\text { oleracea }\end{array}$ & Leaves & $\begin{array}{l}\text { 24-h after Xcc } \\
\text { inoculation (hai) }\end{array}$ & $\begin{array}{l}\text { 2-DE, MALDI } \\
\text { TOF-TOF }\end{array}$ & $\begin{array}{l}\text { Identification of Brassica } \\
\text { oleracea resistance-related } \\
\text { proteins at an early stage of } \\
\text { infection by } X_{C C}\end{array}$ & $\begin{array}{l}\text { Reduction of photosynthesis-related proteins was } \\
\text { observed both in the resistance and susceptible } \\
\text { interactions. Also, decreased abundance of } \\
\text { ubiquitin (to stop the bacteria from using } \\
\text { ubiquitination pathway) and malate dehydrogenase } \\
\text { (to reduce energy metabolism in the early stage of } \\
\text { infection) were found playing important role in the } \\
\text { resistance mechanism against Xcc. }\end{array}$ & $\begin{array}{l}\text { Ribeiro } \\
\text { et al., } 2018\end{array}$ \\
\hline $\begin{array}{l}\text { Brassica } \\
\text { oleracea }\end{array}$ & Leaves & $\begin{array}{l}\text { 3- and 12-days } \\
\text { post-infection }\end{array}$ & $\begin{array}{l}\text { MALDI-TOF- } \\
\text { TOF }\end{array}$ & $\begin{array}{l}\text { To investigate the molecular } \\
\text { changes at the protein level } \\
\text { in Brassica oleracea plants } \\
\text { infected by Xcc }\end{array}$ & $\begin{array}{l}\text { Proteins shared between early and late response } \\
\text { were related to photorespiration, calvin cycle and } \\
\text { light reactions, and are strongly down-regulated } \\
\text { after } X_{c c} \text { infection. Proteins related with } \\
\text { glucosinolates degradation (myrosinase) were } \\
\text { up-regulated in both early and late response. } \\
\text { Proteins related with signalling were up-regulated in } \\
\text { late response }\end{array}$ & $\begin{array}{l}\text { Tortosa } \\
\text { et al., } 2018 \text { a }\end{array}$ \\
\hline $\begin{array}{l}\text { Brassica } \\
\text { oleracea var. } \\
\text { capitata }\end{array}$ & Leaves & $\begin{array}{l}24-h \\
\text { after infiltration } \\
\text { (hai) }\end{array}$ & LC-MS/MS & $\begin{array}{l}\text { Proteomic analysis of } \\
\text { cabbage inoculated with } \\
X_{C C} \text { and functional } \\
\text { validation of Brassica } \\
\text { oleracea endochitinase } \\
\text { involved in resistance to } \\
X_{C C}\end{array}$ & $\begin{array}{l}\text { Differentially abundant proteins were involved in cell } \\
\text { metabolism, protein biosynthesis, processing and } \\
\text { degradation, photosynthesis and disease/defence } \\
\text { response. A CHI-B4 like gene, encoding an } \\
\text { endochitinase showed a high increased abundance } \\
\text { in resistant Xcc-inoculated leaves and was } \\
\text { functionally validated in Arabidopsis thaliana }\end{array}$ & $\begin{array}{l}\text { Santos C. } \\
\text { et al., } 2019\end{array}$ \\
\hline $\begin{array}{l}\text { Brassica } \\
\text { napus }\end{array}$ & Leaves & $\begin{array}{l}\text { 14-days after } \\
\text { inoculation }\end{array}$ & LC-MS/MS & $\begin{array}{l}\text { Quantitative proteomic } \\
\text { analysis of susceptible and } \\
\text { resistant Brassica napus } \\
\text { cultivars infected with } X_{c c}\end{array}$ & $\begin{array}{l}\text { All proteins involved in protein degradation and C2 } \\
\text { oxidative cycle and glycolysis, innate } \\
\text { immunity-related proteins (zinc finger domain } \\
\text { (ZFD)-containing protein, glycine-rich RNA-binding } \\
\text { protein (GRP) and mitochondrial outer membrane } \\
\text { porin), PS I proteins, ATP synthase, and } \\
\text { ferredoxin-NADP+ reductase, redox-related } \\
\text { proteins were up-regulated in the resistant cultivar } \\
\text { (cv. Capitol) whereas Photosystem Il-related } \\
\text { proteins were down-regulated }\end{array}$ & $\begin{array}{l}\text { Islam et al., } \\
2021\end{array}$ \\
\hline $\begin{array}{l}\text { Brassica } \\
\text { oleracea }\end{array}$ & $\begin{array}{l}\text { Proteome } \\
\text { of Xcc } \\
\text { extracted } \\
\text { from leaves } \\
\text { of infected } \\
\text { B. oleracea }\end{array}$ & $\begin{array}{l}0-, 1-, 2-, 4- \\
\text { and 6-days } \\
\text { after inoculation } \\
\text { (DAl) }\end{array}$ & $\begin{array}{l}\text { 2-DE, MALDI- } \\
\text { TOF/TOF }\end{array}$ & $\begin{array}{l}\text { To characterize the protein } \\
\text { expression of } X_{c c} \text { in close } \\
\text { interaction with } B \text {. oleracea }\end{array}$ & $\begin{array}{l}\text { Several proteins expressed in vivo were identified } \\
\text { and were related mainly to metabolism. }\end{array}$ & $\begin{array}{l}\text { Andrade } \\
\text { et al., } 2008\end{array}$ \\
\hline $\begin{array}{l}\text { Brassica } \\
\text { oleracea }\end{array}$ & $\begin{array}{l}\text { Proteome } \\
\text { of } X_{C c} \\
\text { extracted } \\
\text { from leaves } \\
\text { of infected } \\
\text { B. oleracea }\end{array}$ & $\begin{array}{l}0-, 1-, 2 \text { - and } \\
\text { 3-days after } \\
\text { inoculation } \\
\text { (DAl) }\end{array}$ & 2-DE & $\begin{array}{l}\text { To analyze the expressed } \\
\text { proteins of } X_{C C} \text { exclusive to } \\
\text { resistance interaction in } \\
\text { B. oleracea }\end{array}$ & $\begin{array}{l}\text { Protein profile comparison revealed a group of } \\
\text { proteins exclusive to the resistance interaction like } \\
\text { Rubisco. Upregulation of proteins involved in } \\
\text { photosynthesis in the resistance interaction } \\
\text { included intact Rubisco subunits and an } \\
\text { oxygen-evolving protein. The presence of different } \\
\text { isoforms of the same protein in the resistance and } \\
\text { the susceptible interactions indicated that the same } \\
\text { protein may play different roles depending on the } \\
\text { types of interaction. }\end{array}$ & $\begin{array}{l}\text { Villeth et al., } \\
2009\end{array}$ \\
\hline
\end{tabular}


TABLE 4 | (Continued)

\begin{tabular}{|c|c|c|c|c|c|c|}
\hline Species & $\begin{array}{l}\text { Plant } \\
\text { organ }\end{array}$ & $\begin{array}{l}\text { Time point } \\
\text { (Tissue } \\
\text { collection) }\end{array}$ & Methodology & Objective & Inference & References \\
\hline $\begin{array}{l}\text { Brassica } \\
\text { oleracea }\end{array}$ & $\begin{array}{l}\text { Proteome } \\
\text { of Xcc } \\
\text { extracted } \\
\text { from leaves } \\
\text { of infected } \\
\text { B. oleracea }\end{array}$ & $\begin{array}{l}0-, 24-, 48- \\
72-, \text { and } 120-h \\
\text { after inoculation } \\
\text { (hai) }\end{array}$ & $\begin{array}{l}\text { 2D-nano } \\
\text { UPLC/MS }\end{array}$ & $\begin{array}{l}\text { To study the interaction of } \\
B \text {. oleracea-Xcc using an } \\
\text { in vivo system to identify } \\
\text { proteins involved in } \\
\text { pathogenicity }\end{array}$ & $\begin{array}{l}\text { Pathogenicity related proteins [acetylornithine } \\
\text { (ArgD)] and several defence and stress-related } \\
\text { proteins (lipoxygenase, annexins, apocitocrome f, } \\
\text { antimicrobial compound phytoalexin) were } \\
\text { observed in the susceptible (REK) and resistant } \\
\text { (REU) Brassica plants, respectively. Also, proteins } \\
\text { associated with photosystems were identified in the } \\
\text { resistant plants. A model of Xcc-susceptible host } \\
\text { interaction was proposed and showed that Xcc } \\
\text { increases the abundance of several crucial proteins } \\
\text { for infection and cell protection. }\end{array}$ & $\begin{array}{l}\text { Santos } \\
\text { et al., } 2017\end{array}$ \\
\hline
\end{tabular}

expected, most of the photosynthesis-related proteins showed decreased abundance (18\%) in the resistance interactions, whereas in the susceptible interaction, increased abundance of proteins was observed consistent with the previous result obtained by Ribeiro et al. (2018). Additionally, proteome analysis revealed the differentially abundant proteins involved in cell metabolism, protein biosynthesis, processing and degradation, and disease/defence response. Among the genes encoding differential proteins, the functional validation of a CHI-B4 like gene encoding an endochitinase showed that the transgenic plants were highly resistant to $X c c$ compared to the wild type which may assist the future breeding programs targeting at black rot resistance in B. oleracea. Islam et al. (2021) described the down-regulation of photosystem II (PS II)related proteins in the resistant B. napus cultivar (cv. Capitol) while the PS I proteins, ATP synthase, and ferredoxin-NADP ${ }^{+}$ reductase were up-regulated during the characterisation of the resistance mechanisms in the $B$. napus-Xcc pathosystem. In the resistant cultivar, the innate immunity-related proteins [Zinc finger SWIM domain-containing 7 isoform X2 (ZFD), glycinerich RNA-binding GRP1A isoform X1 (GRP1A) proteins and mitochondrial outer membrane porin] were highly enhanced. Also, redox-related proteins (thioredoxin, 2-cys peroxiredoxin, and glutathione S-transferase) were up-regulated in the resistant cultivar with high $\mathrm{NADH}$, ascorbate, and glutathione-based reducing potential. However, the proteins mostly involved in protein degradation, C2 oxidative cycle and glycolysis were highly activated in the susceptible cultivar (cv. Mosa).

In summary, though comparative proteomic analysis is an efficient and powerful approach to understand the defence mechanisms of Xcc-Brassica pathosystem, proteomic studies are still at the infancy stage except a handful of works unlike the genomic and transcriptome studies. Nevertheless, the proteomic analysis identified proteins related to photosynthesis, energy metabolism, innate immunity, ROS production and proteolysis, redox homeostasis, and defence signalling pathways involved in the Xcc-Brassica interaction. Specifically, most of the studies focused on the regulation of the photosynthesisrelated proteins as a resistance response in both early and later stages of infection. It is suggested that in Brassica, during resistance interactions, photosynthesis is increased at later stages of infection while it is down-regulated at early stages. So, it was hypothesized that the plant tries to minimize the damage caused by $X c c$ by regulating photosynthesis-related proteins. Additionally, decreased abundance of ubiquitin and of malate dehydrogenase was hypothesized to play an important role in the resistance mechanisms against Xcc. ZFD and GRP1A proteins were up-regulated in the resistant plants and could be the key regulators of ETI driven innate immunity against $X c c$ in Brassica species. Also, R-protein-mediated mitochondrial permeability transition (MPT) enhanced the accumulation of mitochondrial outer membrane porin triggering programmed cell death, thereby inducing resistance to $X c c$.

\section{Metabolomics}

Metabolome is the complete set of metabolites present in an organism, organ, tissue, and metabolomics refer to the comprehensive profiling of the metabolome of an organism in a particular moment. Metabolomics lies at the phenotypic end of the omics spectrum, capturing the results beginning with the genome and progressing through the transcriptome and proteome (Liu and Locasale, 2017). Metabolomics is the newest among the '-omic' spectrum and has a broad field to develop. Generally, metabolomics is used in combination with transcriptomics or proteomics to investigate the correlation between metabolite levels and genes or protein expression level (Srivastava et al., 2013). The metabolome mainly consists of primary metabolites (involved in the basic functions of the living cell) and secondary metabolites (play important role in plant defence against pests and diseases, Verpoorte et al., 2007). The field of metabolomics has rapidly grown in the past two decades thanks to the advancement in analytical methods and data analysis allowing the understanding of a vast diversity of metabolites within a given sample. Among several stateof-the-art analytical instruments and separation technologies, nuclear magnetic resonance (NMR), gas/liquid chromatography coupled with mass spectrometry (GC-MS/LC-MS), and capillary electrophoresis/mass spectrometry (CE-MS) are the most widely used tools (Jorge et al., 2016) to capture and quantify a wide range of primary and secondary metabolites. Specifically, GCMS and LC-MS has become fundamental tools to study the biochemical behaviour of plants exposed to pathogen attack 
(Arbona and Gomez-Cadenas, 2016) due to their unparalleled sensitivity in quantifying many types of phytochemicals.

In plant pathology, metabolomics deals with the profiling of host plant metabolites in response to pathogen infection which helps in the understanding of the host-pathogen interactions through activation/deactivation of metabolites and related signalling pathways (Castro-Moretti et al., 2020). Upon pathogen attack, plants develop different strategies by modifying gene expression and activating metabolic pathways which may accumulate toxic metabolites, thereby killing the pathogen or limiting the damages. Metabolomics has been used to study plant-biotic stress interactions (Tenenboim and Brotman, 2016). The identification of a wide spectrum of compounds synthesized by the plants in response to biotic stresses provides a better understanding of the regulatory processes underlying stress conditions (Badjakov et al., 2012). Over the years, several authors have evaluated the effects of secondary metabolites, glucosinolates, and its hydrolysis products (GHP), conferring resistance to black rot in Brassica crops (Table 5). In B. oleracea, LC/MS-based metabolite profiling during $X c c 1$ infection revealed the dynamic metabolic changes occurring in the host cell after $48 \mathrm{~h}$ of infection, indicating a complex temporal response (Tortosa et al., 2018b). Furthermore, photosynthesis, alkaloids, coumarins, and sphingolipids were shown to play key roles in the metabolic pathways involved in the infection process. Metabolite profiling of a vast number of compounds present in plants could be accomplished by both targeted (Griffiths et al., 2010) and untargeted metabolomic (Schrimpe-Rutledge et al., 2016) approaches. The untargeted approach deals with both the secondary (polyphenols and carotenoids) and primary metabolites, whereas the targeted approach mostly focused on the identification glucosinolates.

Glucosinolates (GSLs) are the unique components of metabolome (Verkerk et al., 2009) found in Brassica vegetables which are structurally highly diverse and mainly fall into three classes such as aliphatic, indole, and aromatic glucosinolates. GSLs are involved in defence mechanisms against plant pathogens, insects, and nematodes (Bennett and Wallsgrove, 1994; O'Callaghan et al., 2000; Buskov et al., 2002; Serra et al., 2002; Kliebenstein, 2004). Brassicaceae family is mostly dominated by aliphatic and indolic glucosinolates (Fahey et al., 2001; Bekaert et al., 2012). The breakdown products of both aliphatic and indolic glucosinolates by an endogenous myrosinases enzyme (b-thioglucoside glucohydrolases) were found to have anti-fungal and anti-bacterial properties in different crops (Manici et al., 1997; Agerbirk et al., 1998; Brader et al., 2001; Tierens et al., 2001; Stotz et al., 2011; Calmes et al., 2015). Several in vivo and in vitro experiments were conducted to estimate the effect of GSLs and their hydrolysed products (GHP) for disease resistance in Brassica crops. Transgenic A. thaliana with modified glucosinolates profile enhanced the resistance against Erwinia carotovora and Pseudomonas syringae pv. maculicola (Brader et al., 2006). In B. napus, cultivars with higher GSL content showed resistance against Alternaria spp. and Leptosphaeria maculans compared to cultivars with low GSLs (Giamoustaris and Mithen, 1995). The in vitro effect of GHP, especially different isothiocyanates (benzylisothiocyanate, 2-phenylethylisothiocyanate, the isothiocyanate mix and sulforaphane) were found effective against six plant pathogenic bacteria such as Agrobacterium tumefaciens, Erwinia chrysanthemi, Pseudomonas cichorii, Pseudomonas tomato, Xanthomonas campestris, and Xanthomonas juglandin (Aires et al., 2009). Though several research projects were dedicated to elucidate the role of GSLs and GHP against fungal pathogens, fewer studies were conducted with pathogenic bacteria and much less with Xcc (Table 5). Several studies have stated that indolic GSLs are related to the resistance to necrotrophs, biotrophs, and hemibiotrophs in Brassica crops (Hiruma et al., 2013). Xcc being a hemibiotropic pathogen, the role of GHP was evaluated against Xcc infection in various Brassicaceae seedlings and positive correlations were found between specific and total GSL contents and the severity of Xcc infection, though no significant correlations were reported between $X c c$ infection and total phenolics (Aires et al., 2011). Nevertheless, the susceptibility of the Brassica plants against Xcc was found to be higher in plants with lower contents of aromatic-GSLs and glucoraphanin, both acting as inhibitors of $X c c$. This necessitates further requirements of clear and detailed in vitro studies to evaluate the role of GSLs and its GHP in defence mechanisms against Xcc. So, experiments were carried out to evaluate the in vivo and in vitro antibacterial activities of gluconapin, its isothiocyanate (ITC) against Xcc type 4 in B. rapa (Velasco et al., 2013). The results demonstrated gluconapin and its ITC varieties possessing antibacterial effect on the development of Xanthomonas, and gluconapin playing a role in imparting constitutive resistance to $X c c$. Additionally, the methanolic extracts of $B$. rapa containing glucosinolates and phenolic compounds curbed the growth of Xcc. Though GSLs and its hydrolytic products show a wide range of antimicrobial activities, our knowledge on the role of specific metabolites in defending the Brassica crops and their interactions with the pathogens is poorly understood. So, the individual role of two aliphatic (sinigrin, glucoiberin) and one indolic (glucobrassicin) GSLs against Xcc was explored in B. oleracea var. acephala L. (kale) and the indolic GSL glucobrassicin was found inhibitory to Xcc infection than the aliphatic GSLs (Madloo et al., 2019). Interestingly, the results indicated that increasing the amount of a particular GSL may not always result in disease resistance. Instead, its effects are dependent on the pathogen and the type of GSLs. Also, factors like modification of the metabolites during pathogen infection may regulate its affect in inhibiting the pathogens. This is noteworthy as the host genotypes exhibit different GSL profiles and concentrations in different genetic backgrounds.

The variation in GSL contents could happen due to the allelic variation of GSL biosynthesis genes (Rangkadilok et al., 2002). In B. oleracea, three loci (GSL-PRO, GSL-ELONG, and GSL-ALK) were reported to regulate the aliphatic GSL profile (Li et al., 2001). In Arabidopsis, upon fungal infection, the CYP81F2 gene is expressed resulting in the hydrolysis of GSLs by PENETRATION2 (PEN2) and accumulated as indolic 4-methoxy-glucobrassicin in cells (Bednarek et al., 2009). But the information about GSL-regulated resistance mechanisms, expression profiling of GSL biosynthesis genes, and interaction between GSL profiles of black rot susceptible and resistant 
TABLE 5 | Published metabolomic analyses in Brassica species involved in resistance against black rot.

\begin{tabular}{|c|c|c|c|c|c|c|}
\hline Species & $\begin{array}{l}\text { Plant } \\
\text { organ }\end{array}$ & $\begin{array}{l}\text { Time point } \\
\text { (Tissue } \\
\text { collection) }\end{array}$ & Methodology & Objective & Inference & References \\
\hline $\begin{array}{l}\text { Different } \\
\text { Brassicaceae } \\
\text { crops }\end{array}$ & $\begin{array}{l}\text { Leaves and } \\
\text { stems }\end{array}$ & $\begin{array}{l}\text { 10-days post- } \\
\text { inoculation }\end{array}$ & Spectrophotometer & $\begin{array}{l}\text { To evaluate the potential role of } \\
\text { glucosinolates and their hydrolysis products } \\
\text { against } X_{C C} \text { infection in different crops of } \\
\text { Brassicaceae }\end{array}$ & $\begin{array}{l}\text { Various Brassicaceae seedlings shown a correlation between } \\
\text { GLS profiles, and their subsequent hydrolysis products, and the } \\
\text { inhibition of XCC growth. Positive correlations were found between } \\
\text { specific and total GSL contents and the severity of disease. }\end{array}$ & $\begin{array}{l}\text { Aires et al., } \\
2011\end{array}$ \\
\hline Brassica rapa & Leaves & $\begin{array}{l}0-, 24-, \text { 48-, } \\
\text { 72-, 168-h after } \\
\text { the inoculation }\end{array}$ & HPLC & $\begin{array}{l}\text { To evaluate the in vivo and in vitro } \\
\text { antibacterial effect of glucosinoates and its } \\
\text { hydrolysis products and phenolic } \\
\text { compounds against } X_{C C}\end{array}$ & $\begin{array}{l}\text { Gluconapin plays a role in the constitutive resistance to XCC. } \\
\text { Gluconapin, some flavonoids and hydroxycinnamic acids were } \\
\text { induced by XCC infection. }\end{array}$ & $\begin{array}{l}\text { Velasco } \\
\text { et al., } 2013\end{array}$ \\
\hline $\begin{array}{l}\text { Brassica } \\
\text { napus }\end{array}$ & Leaves & $\begin{array}{l}\text { 14-days post- } \\
\text { inoculation }\end{array}$ & HPLC-ESI-MS/MS & $\begin{array}{l}\text { To elucidate the cultivar variation in disease } \\
\text { susceptibility and disease responses in } \\
\text { relation to hormonal status in the } \\
\text { interactions of Brassica napus cultivars and } \\
\text { XCC }\end{array}$ & $\begin{array}{l}\text { Cultivar variation in susceptibility to infection by } X_{C C} \text { is determined } \\
\text { by the enhanced alteration of the SAJJA ratio with the } \\
\text { antagonistic suppression of JA-regulated gene, as a negative } \\
\text { regulator of redox status and phenylpropanoid synthesis in the } \\
\text { Brasica napus-XCC pathosystem }\end{array}$ & $\begin{array}{l}\text { Islam M.T. } \\
\text { et al., } 2017\end{array}$ \\
\hline $\begin{array}{l}\text { Brassica } \\
\text { oleracea var. } \\
\text { capitata }\end{array}$ & Leaves & $\begin{array}{l}0-, 1-, 3-, 5-, \\
7-, 9-, \text { and } \\
11-\text { days after } \\
\text { inoculation } \\
\text { (DAl) }\end{array}$ & Spectrophotometer & $\begin{array}{l}\text { To gain a better understanding of the } \\
\text { interaction between } X_{C C} \text { and cabbage and } \\
\text { the changes in the expression of the key } \\
\text { defence-related enzymes in compatible } \\
\text { interaction }\end{array}$ & $\begin{array}{l}\text { The susceptibility of cabbage to } X_{C C} \text { is correlated to the } \\
\text { declination of phenylalanine ammonia lyase (PAL) and phenolic } \\
\text { contents }\end{array}$ & $\begin{array}{l}\text { Barman } \\
\text { et al., } 2015\end{array}$ \\
\hline $\begin{array}{l}\text { B. oleracea } \\
\text { var. italica }\end{array}$ & Leaves & $\begin{array}{l}\text { 3- and } 12 \text {-days } \\
\text { post-infection }\end{array}$ & UHPLC-QTOF & $\begin{array}{l}\text { Metabolite profiling of } B \text {. oleracea } \\
\text { challenged with } X_{C C}\end{array}$ & $\begin{array}{l}\text { The number of compounds belonging to coumarin family } \\
\text { changed during Xcc infection, especially during the early } \\
\text { response. Alkaloid metabolism was modified in response to } \\
\text { infection in both 3-and 12-dpi. }\end{array}$ & $\begin{array}{l}\text { Tortosa } \\
\text { et al., 2018a }\end{array}$ \\
\hline $\begin{array}{l}\text { Brassica } \\
\text { oleracea }\end{array}$ & Leaves & $\begin{array}{l}1-, 2-, 3-, 6- \\
\text { and 12-days } \\
\text { post- } \\
\text { inoculation }\end{array}$ & LC/MS & $\begin{array}{l}\text { To unravel the metabolomic response of } \\
\text { B. oleracea infected with } X_{C C} \text { race } 1\end{array}$ & $\begin{array}{l}\text { XCC infection caused dynamic changes in the metabolome of } \\
\text { B. oleracea. Alkaloids, coumarins or sphingolipids, were } \\
\text { postulated as promising key candidates in the infection response }\end{array}$ & $\begin{array}{l}\text { Tortosa } \\
\text { et al., 2018b }\end{array}$ \\
\hline $\begin{array}{l}\text { Brassica rapa } \\
\text { var. } \\
\text { pekinensis }\end{array}$ & Leaves & $\begin{array}{l}\text { 12-days post- } \\
\text { inoculation } \\
\text { (DPI) }\end{array}$ & RP-HPLC & $\begin{array}{l}\text { To characterize } \mathrm{p} \text {-coumaric acid ( } \mathrm{pCA}) \\
\text { induced soluble and cell wall-bound } \\
\text { phenolic metabolites in relation to } \\
\text { resistance against } X_{C C}\end{array}$ & $\begin{array}{l}\text { Lower disease symptom development in pCA-pretreated leaves } \\
\text { was associated with a higher accumulation of hydroxycinnamic } \\
\text { acids and flavonoids, and vice-versa in MDCA- and } \\
\text { non-pretreated (control) leaves. }\end{array}$ & $\begin{array}{l}\text { Islam et al., } \\
2018\end{array}$ \\
\hline $\begin{array}{l}\text { Brassica } \\
\text { napus }\end{array}$ & Leaves & $\begin{array}{l}\text { 7-days post- } \\
\text { inoculation }\end{array}$ & HPLC-ESI-MS/MS & $\begin{array}{l}\text { Role of p-Coumaric acid against resistance } \\
\text { to black rot disease in Brassica napus }\end{array}$ & $\begin{array}{l}\text { Treatment with } p C A \text { primed the } J A \text { signalling-mediated induction } \\
\text { of phenylpropanoid biosynthesis to provoke disease resistance in } \\
B \text {. napus against } X_{C C}\end{array}$ & $\begin{array}{l}\text { Islam et al., } \\
2019 a\end{array}$ \\
\hline $\begin{array}{l}\text { Brassica } \\
\text { napus }\end{array}$ & Leaves & $\begin{array}{l}\text { 14-days post- } \\
\text { inoculation }\end{array}$ & $\begin{array}{l}\text { HPLC-ESI- } \\
\text { MS/MS, RP-HPLC }\end{array}$ & $\begin{array}{l}\text { To investigate the hormonal regulations in } \\
\text { soluble and cell wall-bound phenolic } \\
\text { compound accumulation in the resistant } \\
\text { and susceptible cultivar of Brassica napus }\end{array}$ & $\begin{array}{l}\text { Enhanced JA levels and signalling in resistant cultivar was } \\
\text { associated with a higher accumulation of hydroxycinnamic acids } \\
\text { and flavonoids, particularly in the cell wall-bound form, and vice } \\
\text { versa in the susceptible cultivar with enhanced SA-, ABA-, and } \\
\text { CK- levels and signalling. }\end{array}$ & $\begin{array}{l}\text { Islam et al., } \\
2019 \mathrm{~b}\end{array}$ \\
\hline $\begin{array}{l}\text { Brassica } \\
\text { oleracea var. } \\
\text { acephala }\end{array}$ & Leaves & $\begin{array}{l}21 \text {-days post- } \\
\text { inoculation }\end{array}$ & UHPLC & $\begin{array}{l}\text { To explore the role of major glucosinolates } \\
\text { such as SIN, GIB, GBS in the defense of } \\
\text { Kale against } X_{C C}\end{array}$ & $\begin{array}{l}\text { Increasing the amount of GSLs didn't always result in resistance. } \\
\text { Indolic GSL (glucobrassicin) was found inhibitory to infection by } \\
\text { XCC }\end{array}$ & $\begin{array}{l}\text { Madloo } \\
\text { et al., } 2019\end{array}$ \\
\hline
\end{tabular}




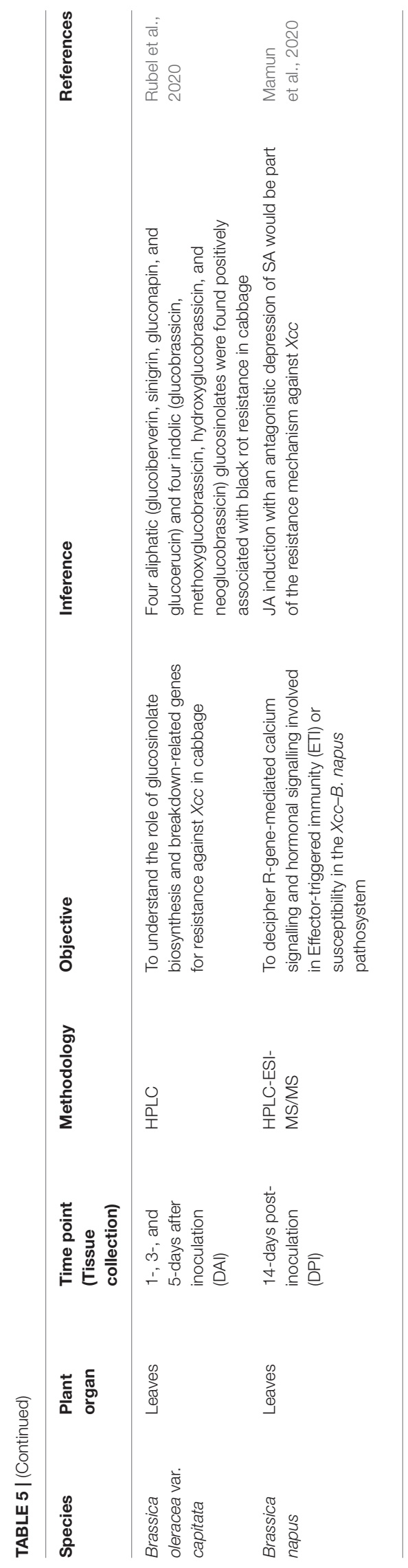

plants is scanty in B. oleracea. In a recent study, the relative expression of 43 GSL biosynthesis and breakdown-related genes were estimated upon Xcc4 inoculation in cabbage (Rubel et al., 2020). In the resistant lines, nine genes showed consistent expression patterns. Expression values of two (ST5C-Bol030757 and AOP2-Bo9g006240) and five genes (MYB34-Bol017062, MYB122-Bol026204, CYP81F2-Bol012237, CYP81F4-Bol032712, and CYP81F4-Bol032714) showed positive association with aliphatic and indolic GSL compounds, respectively. Finally, four aliphatic (glucoiberverin, sinigrin, gluconapin, and glucoerucin) and four indolic (glucobrassicin, hydroxyglucobrassicin, methoxyglucobrassicin, and neoglucobrassicin) compounds were found positively associated with black rot resistance which may help in elucidating the role of GSL biosynthesis and breakdown-related genes in conferring resistance to $X c c$ in cabbage.

The phytohormones, such as JA and SA, are important central defence signalling molecules which maintain complex interactions with each other and other hormones such as ABA, cytokinin, gibberellic acid, and indole acetic acid to regulate defence responses (Anderson et al., 2004; Martínez-Medina et al., 2017). The antagonistic interaction between SA and JA and synergistic interaction of JA with ethylene have been well documented in previous studies (Pieterse et al., 1996; Van Wees et al., 2000). So, elucidation of cultivar variation in relation to hormonal status is significant determinant of disease susceptibility and resistance to $X c c$. In a study, increased ratios of ABA/JA and SA/JA increased the susceptibility to Xcc in the $B$. napus cultivars which acted as a negative regulator of redox status and phenylpropanoid synthesis required for inducing resistance (Islam M.T. et al., 2017). With the enhanced expression of SA signalling regulatory gene NPR 1 and transcriptional factor $T G A 1$, the ratios of $\mathrm{ABA} / \mathrm{JA}$ and SA/JA increased with the antagonistic suppression of JA-regulated gene PDF 1.2, leading to higher susceptibility of the cultivars. Similarly, Mamun et al. (2020) also reported the R-gene-mediated induction of JA with an antagonistic depression of SA for ETI response suggesting the importance of maintaining proper SA/JA ratio in conferring resistance against $X c c$ in B. napus (Figure 3A).

Also, plant phenolics are involved in disease resistance mechanisms in different pathosystems which are synthesized by the phenylpropanoid pathway (Dixon et al., 2002) through the conversion of $p$-coumaric acid ( $p \mathrm{CA}$ ) into hydroxycinnamic acids and flavonoids (Cartea et al., 2011b). Islam M.T. et al. (2017) reported higher accumulation of flavonoids, hydroxycinnamic acids, and proanthocyanidins in the resistant cultivar (cv. Capitol) by the enhanced expression of the phenylpropanoids biosynthesis-related genes (CHS, F5H, and ANR) upon Xcc infection. Furthermore, expression of these genes were found positively correlated with the enhanced expression of JAsignalling gene $P D F 1.2$ resulting in the elevated resistance. This clearly demonstrated that JA positively regulates the phenylpropanoid synthesis pathway and JA-signalling pathway is involved in conferring resistance against hemibiotrophic pathogen like Xcc. The pre-treatment of Chinese cabbage genotypes with $p$-coumaric acid (regulates the phenylpropanoid biosynthesis pathway) alleviated the Xcc symptoms with higher 
accumulation of hydroxycinnamic acids (ferulic acid and sinapic acid) and flavonoids (EGC and EGCG) both in soluble and cell wall-bound form (Islam et al., 2018). The pre-treatment with p-coumaric acid also enhanced the expression of CHS and HCT genes which regulate the synthesis of flavonoids and hydroxy cinnamic acids, respectively, in the phenylpropanoid biosynthesis pathway. The hormonal regulation of $p C A$-induced resistance against $X c c$ was investigated by Islam et al. (2019a) who revealed the enhancement of JA content and expression of signalling genes (COI1 and PDF1.2) in plants pre-treated with $p C A$ in $B$. napus cultivars inoculated with $X c c$. In the $X c c$-inoculated plants, a higher accumulation of total hydroxycinnamic acids and proanthocyanidins were reported along with the upregulation of phenylpropanoids synthesis-related genes in the resistant cultivar. To further investigate if hormonal regulation is associated with the higher accumulation of defensive metabolites synthesized by phenylpropanoid pathway, Islam et al. (2019b) reported that enhanced JA levels and signalling positively regulated the accumulation of phenolic metabolites ( $p$ CA, SiA, FA, NA, and EGCG) in the cell wall-bound form and was associated with antagonistic depression of $\mathrm{SA}, \mathrm{ABA}, \mathrm{CK}$, and IAA-signalling genes in B. napus upon $X c c$ inoculation (Figure 4). This was accompanied by upregulation of PAP1 (production of anthocyanin pigment 1)induced phenylpropanoid biosynthesis genes.

Induced resistance mechanisms are also associated with lignification (Simard et al., 2001) and esterification of cell wall polysaccharides by phenolics (especially with $p C A$, ferulic acid, and sinapic acid) (Azuma et al., 2005; Cvikrová et al., 2006) under pathogen attack. The enhanced activity of two isozymes of peroxidases, guaiacol peroxidase (GPOD), and coniferyl alcohol peroxidase (CPOD) involved in cell wall cross-linking in the resistant cultivar of $B$. napus, ultimately induced resistance against Xcc (Islam et al., 2019b).

\section{KEY GENES AND PATHWAYS RELATED TO BLACK ROT RESISTANCE IN Brassica spp.}

Xcc needs both living and dead tissues for growth and reproduction and is a hemibiotrophic pathogen behaving both as a biotrophic and necrotrophic pathogen. In response to Xcc attack, in B. oleracea, the first layer of basal defence is conferred by pathogen-associated molecular pattern (PAMP)-triggered immunity (PTI) which is overcome by Xcc by delivering the effector proteins into plant cells leading to the suppression of the basal defence of the host. Then, the second level of defence, called ETI, is mediated by the intracellular receptors of the host encoded by the NBS-LRR type R-genes which bind to the pathogen effector proteins and inhibit the bacteria development. In this review, we have discussed the genomics, transcriptomics, proteomics, and metabolomics basis of key genes, proteins, and metabolites involved in the effective responses against Xcc (Figure 5). The genomic studies revealed that the black rot resistance is mostly a complex trait and is controlled by QTLs with minor effects (Table 2) though few scholars have reported major effect
QTLs. While secondary metabolites like GSLs were involved in quantitative resistance against Xcc in B. oleracea, several NBSLRR type R-genes were identified regulating defence response against Xcc. One CC-NB-LRR type R-gene, ZAR1 regulated ETI response to $X c c$ by co-ordinating SA and JA synthesis in B. napus (Figure 3A). Transcriptomic analysis revealed the genes related to photosynthesis (fructose-bisphosphate aldolase), glucosinolate biosynthesis (MYB122-Bol026204, MYB34-Bol017062, AOP2-Bo9g006240, ST5c-Bol030757, CYP81F1-Bol017376, CYP81F2-Bol012237, CYP81F4-Bol032712, CYP81F4-Bol032714, MYB28, FMO GS-OX2, BASS5, MAM2, GSL-OH, and BCAT4) and catabolism (PEN2-Bol030092, TGG2, UGT74 C1, ESP, NSP4, and NSP5), phenylpropanoid biosynthesis pathway [chalcone synthase (CHS), anthocyanidin reductase (ANR), ferulate-5-hydroxylase (F5H), caffeic acid 0-methyltransferase 1 (COMT1), cinnamyl alcohol dehydrogenase 2 (CAD2), production of anthocyanin pigment 1 (PAP1) and MYB transcription factor], ROS scavenging, calcium signalling-related genes (Ca2+ATPase, CDPK5, CBP60g and $C A S$ ), hormonal synthesis (LOX1, LOX2, LOX3, OPR1, OPR2, EDS1, ICS1, ACO1, ACO4, SAM2, and SAM3) and signalling pathway (PDF1.2, MYC2, TGA1, NPR1, NPR3, NPR4, JAZ, EIN3, ERF4, and ERF15), resistance (ZAR1, TAO1), and related genes (NDR1, MAPK6) were differentially expressed upon Xcc infection. Proteomic studies identified the proteins related to photosynthesis (photosystem II CP43 reaction centre protein, photosystem II oxygen-evolving complex protein 2, chlorophyll a-b binding protein CP29.2 and CP26, PS I reaction centre protein, PS I chlorophyll a/b-binding 3, cytochrome b6f complex, ATP synthase, chloroplast beta-carbonic anhydrase, enolase and Ribulose bisphosphate carboxylase), protein biosynthesis, processing and degradation [Clp protease proteolytic subunits $(\mathrm{ClpP})]$, energy metabolism (ubiquitin thioesterase, malate dehydrogenase, mitochondrial pyruvate dehydrogenase, fructose-1,6-biphosphate, basic endochitinase CHI-B4-like and UDP-arabinopyranose mutase 1-like), innate immunity [leucine-rich repeat receptor kinase PEPR1, LRR receptorlike serine/threonine-protein kinase At1g29720 RFK1-like and zinc finger SWIM domain-containing 7 isoform X2 (ZFD), glycine-rich RNA-binding GRP1A isoform $\mathrm{X} 1$ and mitochondrial outer membrane porin], redox homeostasis (superoxide dismutase, peroxidase, catalase, peroxirredoxins, thioredoxin, glutathione S-transferase and ascorbate), defence response [annexin, ferredoxin, ferredoxin-NADP leaf isozyme 1, 2 chloroplastic, mitochondrial outer membrane protein 4, $\mathrm{ABA}$ and epithiospecifier protein (ESP)], and signalling (JAZ) pathways playing major roles in the Xcc-Brassica interaction. Specifically, regulation of the photosynthesisrelated proteins was involved in both early and later stages of infection by Xcc. The decreased abundance of proteins in the resistant plants during early stage of infection suggested that susceptible plants of Brassica spp. require more energy to cope with the infection by Xcc in the initial stage. Metabolomic studies indicated that glucosinolates and its GHP and plant secondary metabolites, including phenolics synthesized by phenylpropanoid biosynthesis pathway are involved in disease resistance mechanisms against Xcc in different Brassica species. 


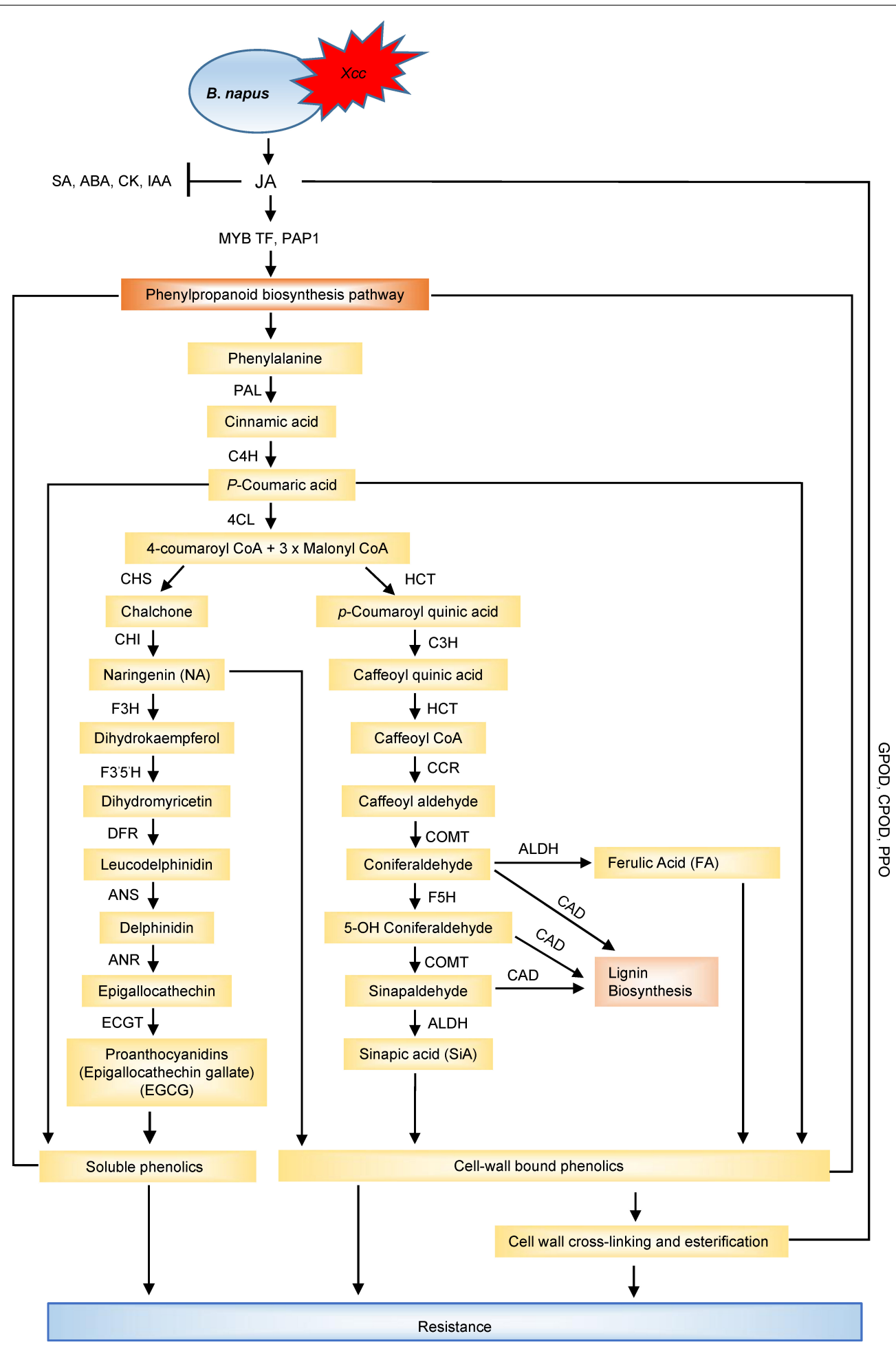

FIGURE 4 | Schematic view of a model depicting Jasmonic acid (JA)-mediated phenylpropanoid biosynthesis pathway and hormonal regulations of phenolic accumulation (soluble and cell-wall bound) in relation to resistance against XCC in Brassica napus adopted from previous studies (Islam et al., 2018, 2019b). JA, jasmonic acid; SA, salicylic acid; ABA, abscisic acid; CK, cytokinin; IAA, indoleacetic acid; MYB TF, MYB transcriptional factor; PAP1, production of anthocyanin pigment 1; PAL, phenylalanine ammonia-lyase; $\mathrm{C} 4 \mathrm{H}$, cinnamate-4-hydroxylase; 4CL, 4-coumaroyl CoA-ligase; $\mathrm{CHS}$, chalcone synthase; $\mathrm{CHI}$, chalcone isomerase; F3H, flavanone 3- hydroxylase; F3'5'H, flavonoid 3',5'hydroxylase; DFR, dihydroflavanol 4-reductase; ANS, anthocyanidin synthase; ANR, anthocyanidin-reductase; ECGT, epicatechin:1-O-galloyl- $\beta$-D-glucose-O-galloyltransferase; HCT, hydroxycinnamoyl-CoA:shikimate hydroxycinnamoyl transferase; $\mathrm{C} 3 \mathrm{H}$, coumarate 3-hydroxylase; CCR, cinnamyl CoA reductase; COMT, caffeic acid O methyltransferase; ALDH, aldehyde dehydrogenase; F5H, ferulate 5- hydroxylase; CAD, cinnamyl alcohol dehydrogenase; GPOD, guaiacol peroxidases; CPOD, coniferyl alcohol peroxidase; PPO, polyphenol oxidase. 
A number of in vivo and in vitro studies evaluated the effects of GSLs and their potential role against Xcc infection and it could be concluded that aliphatic (sinigrin, gluconapin, glucoiberverin glucoerucin, and glucoiberin) and indolic (glucobrassicin, hydroxyglucobrassicin, mythoxyglucobrassicin and neoglucobrassicin) GSLs present in different tissues of Brassica species are associated positively in conferring resistance against $X c c$. Fine tuning of hormonal signalling plays a significant role to activate immune response against pathogens. Calcium signalling regulate the PTI or ETI in plants (Bigeard et al., 2015) and different calcium signalling genes play potential roles during host defence against Xcc (Tortosa et al., 2019). R-genes played significant role to induce different hormonal signalling through calcium signalling during Brassica-Xcc interaction (Mamun et al., 2020). The phytohormones, SA and $\mathrm{JA}$, are regarded as the central regulators in host defence against biotrophic and hemibiotrophic pathogens, respectively, and are mutually antagonistic (Tortosa et al., 2019; Vega-Álvarez et al., 2021). Several studies conducted by different authors indicated that disease resistance and susceptibility to $X c c$ infection is dependent on alteration of the SA/JA ratio (Islam M.T. et al., 2017; Islam et al., 2019b; Mamun et al., 2020). The enhanced alteration of the SA/JA ratio determined the susceptibility whereas the enhanced JA levels and signalling with antagonistic depression of SA induced resistance against Xcc in Brassica species. Taken together, we could suggest that JA signalling pathway is playing a critical role in conferring host resistance against $X c c$ in Brassica species (Figures 3A,B, 4). Furthermore, the "hormonal crosstalk" among various hormone signalling pathways is believed to be widely involved in Xcc resistance in Brassica species. In this review, we have observed that JA is mediating the phenylpropanoid biosynthesis pathway to impart resistance toward Xcc through the accumulation of defensive metabolites. Increased ratios of SA/JA and ABA/JA up-regulated the SA signalling regulatory genes, thereby negatively regulating phenylpropanoid synthesis. Metabolomic studies have thrown insight on how phenylpropanoid biosynthesis pathway is serving as a rich source of phenolics including hydroxycinnamic acids ( $p$-coumaric acid, ferulic acid, and sinapic acid) and flavonoids (naringin and epigallocathechin gallet), both in soluble and cell-wall bound form to confer resistance against Xcc.

\section{CHALLENGES AND FUTURE PERSPECTIVES}

In recent years, most of the plant researchers have focused on host-pathogen interactions as pathogen attack involves many dynamic changes in the host plant which ultimately define the resistance or susceptibility of the plant. Host-pathogen interaction is a complex phenomenon and had always fascinated the plant researchers. Hence, a great research emphasis has been put to understand the mechanisms underlaying resistance. In the recent decades, significant advances were made in understanding the resistance mechanisms for biotic stresses at the molecular level in Brassica crops. The complex genetic and molecular processes involved in defence response have necessitated the use of advance technologies to integrate all the biological informations, and to analyse it jointly. The ever-growing demand for improved crop varieties have forced the researchers to adopt omics-based technologies to enhance crop productivity. Integrated multi-omics approaches could provide important insights to understand the complex host-pathogen interactions. Multi-omics approaches are beneficial as it could provide large scale insights into complex plant systems (Suravajhala et al., 2016) instead of using single 'omic' alone.

Often, protein and metabolite expression differ with that of mRNA expression of the corresponding genes. Therefore, proteomic and metabolomic research should be given due importance as they are the end products of the central dogma. If these approaches are integrated correctly at the right scale, they may reveal a multi-dimensional view of the plant diseases (Crandall et al., 2020). Multi-omics technologies combined with the computational systems may identify the mimicking molecules in the host and/or pathogen triggering the plant defence systems (Pathak et al., 2017). In recent years, breakthroughs in omics technologies have been made in several model plants, but such applications are still in the infancy stage in B. oleracea. Most of the 'omics' research in Brassica species have focused on fungal diseases than the bacterial or viral pathogens. The availability of draft genome sequence and the advancement of sequencing technologies have triggered substantial progress in genomics and transcriptomics in B. oleracea, but the two other major branches of 'omics', proteomics and metabolomics, are lagging behind. So, the questions and bottlenecks which restrict the implementation of omics approaches for black rot resistance need to be studied.

The inheritance of black rot resistance is complex and contradictory which act as a bottleneck in a conventional breeding programme. Compared to B. oleracea, related Brassica species such as 'A' and 'B' genomes are the potential sources of black rot resistance. Furthermore, the favourable alleles of diverse resistance genes present in the wild relatives of $B$. oleracea need to be screened to explore how the resistance gene expression is carried out by regulators such as small RNAs (Zhang et al., 2019). The process of utilizing wild diversity need to be fast-tracked so that genomic part of the loci linked to QTLs for black rot resistance could be explored. The identification of new resistance genes in alien Brassica species and availability of linked markers will assist in the development of pre-breeding black rot resistant genetic stocks/lines through marker-assisted backcross breeding in B. oleracea.

Due to large-scale whole-genome resequencing, sequencebased markers such as SNPs and InDels have been generated which could be the basis of large application of GWAS and biparental QTL mapping projects for disease resistance, especially for black rot in B. oleracea. Additionally, the validated markers need to be converted to 'breeder-friendly' markers for effective use in marker-assisted selection programme. Several methods like eQTL/eGWAS, pQTL/pGWAS, and mQTL/mGWAS where transcript, protein, and metabolite profiles serve as phenotypic information to detect the loci controlling their expression levels can be used to understand the $X c c-B$. oleracea pathosystem. These approaches have been successfully utilized in several species for crop improvements (Zhu et al., 2016; Fang and Luo, 2019; 


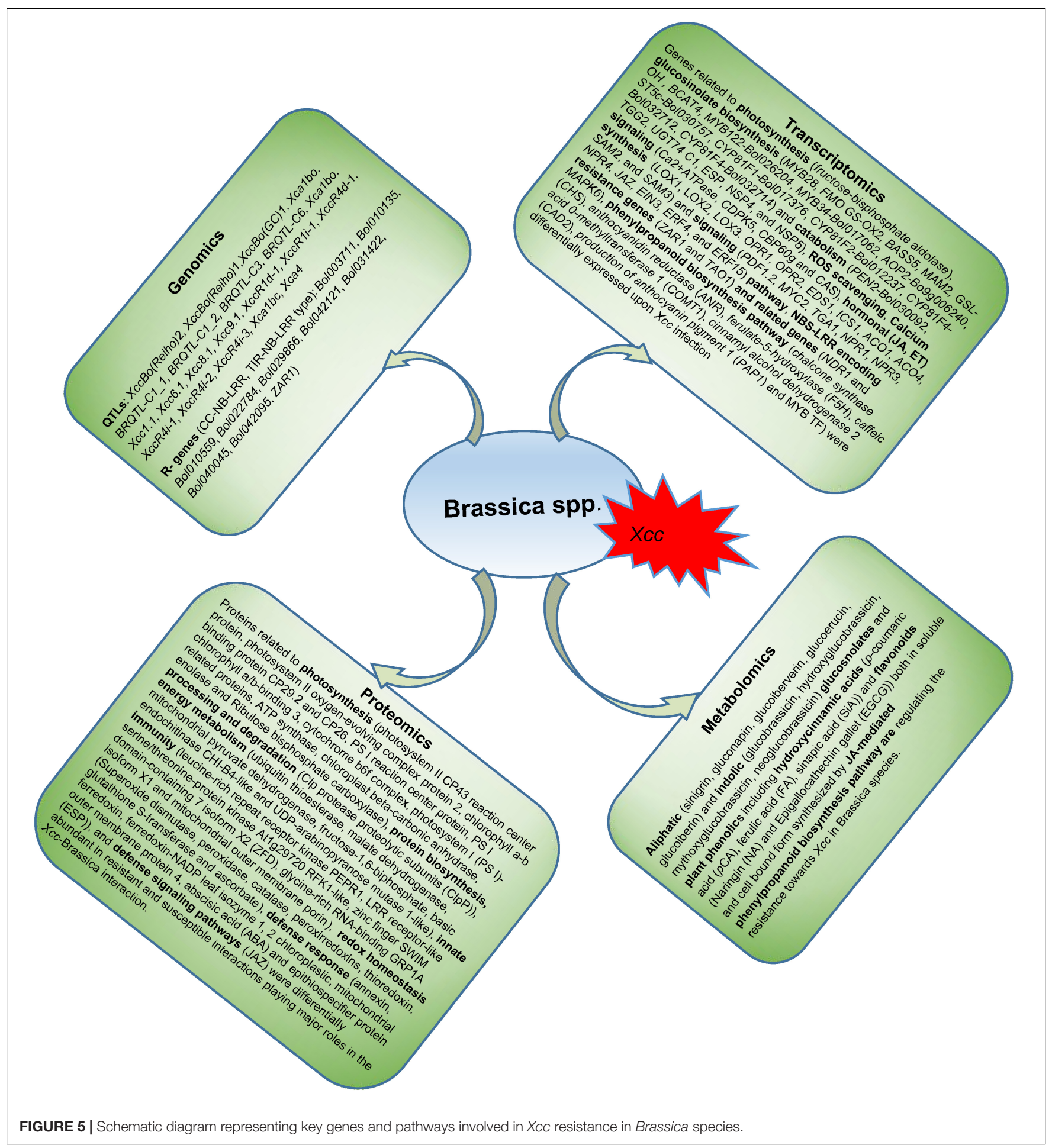

Gu et al., 2019). Although several QTL mappings were conducted and a number of genes for black rot resistance were reported in different Brassica species, none has been cloned. So, future efforts in the direction of map-based cloning are essential to identify the candidate genes responsible for black rot resistance. Furthermore, other mapping approaches such as MutMap (Abe et al., 2012), MutMap+ (Fekih et al., 2013), and MutMap-Gap
(Takagi et al., 2013) could be utilized effectively to identify the loci responsible for black rot resistance. Also, due to prevalence of many races in black rot, gene pyramiding strategy will aid in the development of B. oleracea with durable resistance.

Development of high-throughput phenotyping platforms, establishment of robust glasshouse-based phenotyping methods, and phenotyping of large populations across environments and 
developmental stages during disease progress are the bottlenecks in resistance breeding. So, introduction of phenomics via advanced sensors, cameras, robotics, and image analysis tools holds promise in revealing the genetic mechanisms underlying disease resistance (Houle et al., 2010). Also, targeting the whole crop system via quantitative and automated screening and selection methods could be possible through the advancement of omics technology bridging the gap between the genotype to phenotype. Omics technologies have the potential to develop 'smart crops' being sustainable for abiotic and biotic stresses with higher productivity.

Gene editing technologies viz. CRISPR/Cas, zinc finger nucleases (ZFNs), and transcription activator like effector nucleases (TALENs) are promising tools which have enormous potential to boost resistance against black rot. Using CRISPR/Cas9 system, functional analysis of candidate genes regulating resistance against $S$. sclerotiorum was carried out in B. napus (Sun et al., 2018). The knockout of the BnWRKY70 gene encoding WRKY transcription factors in B. napus exhibited enhanced resistance to sclerotinia. Genomic selection may prove to be a powerful approach for molecular breeding of disease resistance governed by minor genes (Poland and Rutkoski, 2016). So, the scope of implementing genomic selection for black resistance to develop high quality resistant varieties need to be explored in B. oleracea, which is basically a quantitative trait. A deep insight into epigenetics could reveal how it affects the response of a plant to pathogen attack, thereby adding a new dimension to understand the host-pathogen interactions. Transposable elements were reported to contribute to disease resistance and susceptibility in Brassica crops (Alonso et al., 2019; Tirnaz and Batley, 2019). In Arabidopsis-P. brassicae pathosystem based epigenotyped epigenetic RILs, DNA methylation was found to be contributing towards quantitative resistance against clubroot (Liégard et al., 2019). Exploring the epigenetic variability regulating the phenotypic response of B. oleracea towards black rot would be exciting.

Insufficient knowledge of the omics tools, especially proteomics and metabolomics, may act as a significant barrier for functional characterisation of black rot resistance genes. Metabolomics provide a broader, deeper, and an integral perspective of metabolic profiles in stressed conditions. In B. oleracea, metabolomic research has mostly focused on glucosinolates. Therefore, the precise identification of leftover metabolites remains a challenge. Also, availability of low number of metabolites is another bottleneck in the identification of metabolites involved in highly complex mechanisms like hostpathogen interactions. Mathematical models can support the metabolic pathway analysis to study the behaviour of cells carrying out a particular function in multicellular organisms (Neik et al., 2020). Through system biology, a genome-scale metabolic model of $S$. sclerotiorum was made to assess the metabolic activity in several components of the hyphal cells of A. thaliana-S. sclerotiorum pathosystem which revealed that cooperation in $S$. sclerotiorum hyphal cells is essential for host colonisation and virulence (Peyraud et al., 2019). The metabolic pathway for JA signalling in the BrassicaAlternaria pathophysiology was modelled through system biology to identify important elements regulating the resistance mechanisms in Brassica crops (Pathak et al., 2017).

The omics era has taught us to follow a holistic approach while interpreting the complex biological systems starting from molecular to cellular level (Pathak et al., 2018). As the cost of the omics analyses continues to decrease, different highthroughput omics data are made available. But this has posed a complex challenge to the scientific community as we face difficulties in integrating different kinds of extensive omics data sets which come in different formats requiring the expertise to pre-process, analyse, and interpret the final results (Crandall et al., 2020). These challenges including storage, reproducibility, lack of reference database, and reference phytochemicals for metabolomics can be addressed through collaborative efforts, so that the potential of multi-omics research can be realized. We need improved statistical models with modern computing power to scale up the capabilities and efficiency in integrating the full omics datasets. No single research group can handle the multi-omics data generation on their own. Multi-institutional and cross-team research collaboration can allow information exchange, communication between researchers, integration of expertise and may create breakthroughs and answer the unsolved questions. In the era of genomic revolution, with the emergence of multi-omics platforms, we are moving toward a new era of 'big biological data.' So, development of integrative omics data management systems, bioinformatics tools and algorithms, and building of accessible databases is the need of the hour to address the ever-growing need for big data analysis (Su et al., 2019). Also, publicly available data should be used sensibly necessitating the standardisation of commonly used omics technologies (Hasin et al., 2017). For instance, publishing of new genome version, transcript annotation on a regular basis makes it challenging to compare the RNA-seq expression studies. So, the successful deployment of omics technologies not only require technological advances and minimal analytical challenges, but also need a conceptual shift in the research paradigm (Hasin et al., 2017). While continuous efforts are going on to coordinate between disciplines such as genomics, transcriptomics, proteomics and metabolomics of the plant systems, a new discipline 'crop system biology' has been proposed (Yin and Struik, 2007). Through crop system biology, the physiological and metabolic complexity of the plant diseases can be studied to understand complex interactions between host and pathogen which may unveil the pathways and regulatory networks involved. It could be a complementary approach to connect functional genomics and crop modelling to assist plant breeding in improving the disease resistance of major crops.

With the flooding of enormous omics data, the integration of omics data will lead to the identification of many genes simultaneously for disease resistance thereby shifting the research paradigm from single gene analysis to pathway or network analysis. This may revolutionize the future crop breeding system and ensure the development of disease resistant crops for sustainable agriculture. Furthermore, computational approaches could be implemented to construct network biology utilizing the great amount of data collected through multi-omics technologies to understand the plant-pathogen interactions 
(Botero et al., 2018). No doubt, this will be highly computerintensive, but it will be handy as a powerful tool for in silico assessment of crop response under various pathogen attacks. The phenomenal progress in genomics should prompt the plant researchers to adopt all the innovative approaches to address the important questions in developing disease resistant cultivars for sustainable agricultural production.

\section{CONCLUSION}

Omics tools have demonstrated tremendous potential in advancing our knowledge on the host-pathogen interactions and has opened up new possibilities to rapidly identify QTLs/candidate genes, pathogenicity-related genes, metabolic pathways, and proteins, prompting in-depth cellular and biochemical understanding of resistance mechanisms against a range of pathogens. Through an integrated multi-omics approach, numerous datasets at the genomics, transcriptomics, proteomics, and metabolomics level have been used to elucidate the complex mechanisms and pathways regulating black rot resistance in B. oleracea. Genomic studies revealed that the black rot resistance is mostly a complex trait and is governed by QTLs with minor effects except few major effect QTLs. Transcriptomic analysis divulged the genes related to photosynthesis, glucosinolate biosynthesis and catabolism, phenylpropanoid synthesis, ROS scavenging, calcium signalling, hormonal synthesis, and signalling pathway genes being differentially expressed upon Xcc infection. Due to the availability of sequencing data, substantial progress has been made both in genomics and transcriptomics, but the knowledge on proteins and metabolites directly involved in the complex mechanisms of resistance against black rot is minimal. But the identification of proteome components is a fast-moving area which, by the help of modern analytical techniques like MS platforms, are going to be used widely in Brassica species to provide more information on post-transcriptional modifications. Comparative proteomic analysis identified the involvement of proteins related to photosynthesis, protein biosynthesis, processing and degradation, energy metabolism, innate immunity, redox status, and defence response and signalling pathways in Xcc-Brassica interaction. Specifically, most

\section{REFERENCES}

Abe, A., Kosugi, S., Yoshida, K., Natsume, S., Takagi, H., Kanzaki, H., et al. (2012). Genome sequencing reveals agronomically important loci in rice using MutMap. Nat. Biotechnol. 30, 174-178. doi: 10.1038/nbt.2095

Aebersold, R., and Mann, M. (2003). Mass spectrometry-based proteomics. Nature 422, 198-207. doi: 10.1038/nature01511

Afrin, K. S., Rahim, M. A., Park, J.-I., Natarajan, S., Rubel, M. H., Kim, H.-T., et al. (2018a). Screening of cabbage (Brassica oleracea L.) germplasm for resistance to black rot. Plant Breed. Biotechnol. 6, 30-43. doi: 10.9787/pbb.2018.6. 1.30

Afrin, K. S., Rahim, M. A., Park, J. I., Natarajan, S., Kim, H. T., and Nou, I. S. (2018b). Identification of NBS-encoding genes linked to black rot resistance of the studies focused on the regulation of the photosynthesisrelated proteins as a resistance response in both early and later stages of infection. Also, information about the composition of metabolites could be a powerful mean for improvement of $B$. oleracea for disease resistance. Metabolomic studies suggested that glucosinolates (aliphatic and indolic) and its GHP and phenolics such as hydroxycinnamic acids and flavonoids synthesized by the JA-mediated phenylpropanoid pathway are involved in disease resistance mechanisms against Xcc in Brassica species. Phytohormone studies indicated that JA signalling pathway is regulating resistance against hemibiotrophic pathogen like Xcc in Brassica species. Using of multi-omics tools will definitely speed up the screening of superior alleles responsible for resistance against major pathogens including black rot in B. oleracea and may unveil new horizons for future research. Integration of data from different hierarchies using different mathematical and statistical models will lead to new discoveries involved in crop improvements and will provide ease to the plant breeders. The bonhomie between multi-omics technologies and plant breeding is going to trigger major breakthroughs in the crop improvement and can have the maximum benefits from the minimum in the years to come.

\section{AUTHOR CONTRIBUTIONS}

HG conceived the idea and revised the manuscript. RS wrote the manuscript. HG, ZZ, YS, XS, JW, and HY reviewed and edited the manuscript. All the authors have discussed and agreed to the published version of the manuscript.

\section{FUNDING}

Funding was provided by the National Key Research and Development Program of China (2017YFE0114500 and 2017YFD0101805), the National Science Foundation of China (NSFC) (32002039), the Natural Science Foundation of Zhejiang Province (LQ20C150001), the Science and Technology Department of Zhejiang Province (2016C02051-5), the Zhejiang Academy of Agricultural Sciences for Subject construction, and the National Major Scientific Joint Research of Improved (Broccoli) Varieties of China (2018-2022).

in cabbage (Brassica oleracea var. capitata). Mol. Biol. Rep. 45, 773-785. doi: 10.1007/s11033-018-4217-5

Agerbirk, N., Olsen, C. E., and Sørensen, H. (1998). Initial and final products, nitriles, and ascorbigens produced in myrosinase-catalyzed hydrolysis of indole glucosinolates. J. Agri. Food Chem. 46, 1563-1571. doi: 10.1021/jf9708498

Aires, A., Dias, C. S. P., Carvalho, R., Oliveira, M. H., Monteiro, A. A., Simões, M. V., et al. (2011). Correlations between disease severity, glucosinolate profiles and total phenolics and Xanthomonas campestris pv. campestris inoculation of different Brassicaceae. Sci. Hortic. 129, 503-510. doi: 10.1016/j.scienta.2011.04. 009

Agrios, G. N. (2005). "Chapter twelve - plant diseases caused by prokaryotes: bacteria and mollicutes," in Plant Pathology, 5th Edn, ed. G. N. Agrios (San Diego, CA: Academic Press), 615-703. 
Aires, A., Mota, V. R., Saavedra, M. J., Monteiro, A. A., Simoes, M., Rosa, E. A. S., et al. (2009). Initial in vitro evaluations of the antibacterial activities of glucosinolate enzymatic hydrolysis products against plant pathogenic bacteria. J. Appl. Microbiol. 106, 2096-2105. doi: 10.1111/j.1365-2672.2009.04181.x

Akhtar, J., Singh, B., Kumar, A. K. P., Maurya, A. K., and Dubey, S. C. (2017). Interception of pathogens during quarantine processing: an effort towards safe import of oilseed and vegetable Brassicas germplasm in India. J. Oilseed Brassica $81,120-130$.

Alonso, C., Ramos-Cruz, D., and Becker, C. (2019). The role of plant epigenetics in biotic interactions. New Phytol. 221, 731-737. doi: 10.1111/nph.15408

Alotaibi, F., Alharbi, S., Alotaibi, M., Al Mosallam, M., Motawei, M., and Alrajhi, A. (2021). Wheat omics: classical breeding to new breeding technologies. Saudi J. Biol. Sci. 28:1433. doi: 10.1016/j.sjbs.2020.11.083

Anderson, J. P., Badruzsaufari, E., Schenk, P. M., Manners, J. M., Desmond, O. J., Ehlert, C., et al. (2004). Antagonistic interaction between abscisic acid and jasmonate-ethylene signaling pathways modulates defense gene expression and disease resistance in Arabidopsis. Plant Cell 16, 3460-3479. doi: 10.1105/tpc. 104.025833

Andrade, A. E., Silva, L. P., Pereira, J. L., Noronha, E. F., Reis, F. B. Jr., Bloch, C. Jr., et al. (2008). In vivo proteome analysis of Xanthomonas campestris pv. campestris in the interaction with the host plant Brassica oleracea. FEMS Microbiol. Lett. 281, 167-174. doi: 10.1111/j.1574-6968.2008.01090.x

Arbona, V., and Gomez-Cadenas, A. (2016). Metabolomics of disease resistance in crops. Curr. Issues Mol. Biol. 19, 13-30.

Artemyeva, A. M., Ignatov, A. N., Volkova, A. I., Kocherina, M. N., Konopleva, N. V., and Chesnokov, Y. V. (2018) Physiological and genetic components of black rot resistance in double haploid lines of Brassica rapa L. Agri. Biol. (Sel'skokhozyaistvennaya Biologiya). 53, 157-69.

Azuma, T., Okita, N., Nanmori, T., and Yasuda, T. (2005). Relationship between the deposition of phenolic acids in the cell walls and the cessation of rapid growth in internodes of floating rice. Plant Prod. Sci. 8, 447-453.

Badjakov, I., Kondakova, V., and Atanassov, V. (2012). "Current view on fruit quality in relation to human health," in Sustainable Agriculture and New Biotechnologies, ed. N. Benkeblia (Boca Raton, FL: CRC Press), 303-319. doi: 10.1201/b10977-14

Bae, C., Han, S. W., Song, Y. R., Kim, B. Y., Lee, H. J., Lee, J. M., et al. (2015). Infection processes of xylem-colonizing pathogenic bacteria: possible explanations for the scarcity of qualitative disease resistance genes against them in crops. Theor. Appl. Genet. 128, 1219-1229. doi: 10.1007/s00122-015-2521-1

Barman, A. R., Kamei, A., and Dutta, S. (2015). Defence-related enzymatic response in cabbage to Xanthomonas campestris pv. campestris. Arch. Phytopathol. Plant Prot. 48, 9-12. doi: 10.1080/03235408.2016.113 8620

Bayer, P. E., Golicz, A. A., Scheben, A., Batley, J., and Edwards, D. (2020). Plant pan-genomes are the new reference. Nat. Plants 6, 914-920. doi: 10.1038/ s41477-020-0733-0

Bayer, P. E., Golicz, A. A., Tirnaz, S., Chan, C. K., Edwards, D., and Batley, J. (2019). Variation in abundance of predicted resistance genes in the Brassica oleracea pangenome. Plant. Biotechnol. J. 17, 789-800. doi: 10.1111/pbi.13 015

Beck, H. C., Nielsen, E. C., Matthiesen, R., Jensen, L. H., Sehested, M., Finn, P., et al. (2006). Quantitative proteomic analysis of post-translational modifications of human histones. Mol. Cell Proteomics 5, 1314-1325. doi: 10.1074/mcp. M600007-MCP200

Beckett, P. (2012). “The basics of 2D DIGE," in Difference Gel Electrophoresis (DIGE): Methods and Protocols, eds R. Cramer and R. Westermeier (Totowa, NJ: Humana Press), 9-19. doi: 10.1007/978-1-61779-573-2_2

Bednarek, P., Piślewska-Bednarek, M., Svatoš, A., Schneider, B., Doubský, J., Mansurova, M., et al. (2009). A glucosinolate metabolism pathway in living plant cells mediates broad-spectrum antifungal defense. Science 323, 101-106. doi: $10.1126 /$ science.1163732

Bekaert, M., Edger, P. P., Hudson, C. M., Pires, J. C., and Conant, G. C. (2012). Metabolic and evolutionary costs of herbivory defense: systems biology of glucosinolate synthesis. New phytol. 196, 596-605. doi: 10.1111/j.1469-8137. 2012.04302.x

Belser, C., Istace, B., Denis, E., Dubarry, M., Baurens, F.-C., Falentin, C., et al. (2018). Chromosome-scale assemblies of plant genomes using nanopore long reads and optical maps. Nat. Plants 4, 879-887. doi: 10.1038/s41477-018-02 89-4

Bennett, R. N., and Wallsgrove, R. M. (1994). Secondary metabolites in plant defence mechanisms. New phytol. 127, 617-633. doi: 10.1111/j.1469-8137.1994. tb02968.x

Bigeard, J., Colcombet, J., and Hirt, H. (2015). Signaling mechanisms in patterntriggered immunity (PTI). Mol. Plant 8, 521-539.

Bain, D. C. (1952). Reaction of Brassica seedlings to black rot. Phytopathology 42, 1456-1459.

Botero, D., Alvarado, C., Bernal, A., Danies, G., and Restrepo, S. (2018). Network analyses in plant pathogens. Front. Microbiol. 9:35. doi: 10.3389/fmicb.2018. 00035

Brader, G., Mikkelsen, M. D., Halkier, B. A., and Palva, E. T. (2006). Altering glucosinolate profiles modulates disease resistance in plants. Plant J. 46, 758767. doi: 10.1111/j.1365-313X.2006.02743.x

Brader, G., Tas, E., and Palva, E. T. (2001). Jasmonate-dependent induction of indole glucosinolates in Arabidopsis by culture filtrates of the nonspecific pathogen Erwinia carotovora. Plant Physiol. 126, 849-860. doi: 10.1104/pp.126. 2.849

Buskov, S., Serra, B., Rosa, E., Sørensen, H., and Sørensen, J. C. (2002). Effects of intact glucosinolates and products produced from glucosinolates in myrosinase-catalyzed hydrolysis on the potato cyst nematode (Globodera rostochiensis cv. Woll). J. Agric. Food Chem. 50, 690-695. doi: 10.1021/jf010470s

Büttner, D., and Bonas, U. (2010). Regulation and secretion of Xanthomonas virulence factors. FEMS Microbiol. Rev 34, 107-133. doi: 10.1111/j.1574-6976. 2009.00192.x

Cai, X., Wu, J., Liang, J., Lin, R., Zhang, K., Cheng, F., et al. (2020). Improved Brassica oleracea JZS assembly reveals significant changing of LTR-RT dynamics in different morphotypes. Theor. Appl. Genet. 133, 3187-3199. doi: 10.1007/ s00122-020-03664-3

Calenge, F., Faure, A., Goerre, M., Gebhardt, C., Van de Weg, W. E., Parisi, L., et al. (2004). Quantitative trait loci (QTL) analysis reveals both broad-spectrum and isolate-specific QTL for scab resistance in an apple progeny challenged with eight isolates of Venturia inaequalis. Phytopathology 94, 370-379. doi: 10.1094/phyto.2004.94.4.370

Calmes, B., N'Guyen, G., Dumur, J., Brisach, C. A., Campion, C., Iacomi, B., et al. (2015). Glucosinolate-derived isothiocyanates impact mitochondrial function in fungal cells and elicit an oxidative stress response necessary for growth recovery. Front. Plant Sci. 6:414. doi: 10.3389/fpls.2015.00414

Camargo, L. E. A., Williams, P. H., and Osborn, T. C. (1995). Mapping of quantitative trait loci controlling resistance of Brassica oleracea to Xanthomonas campestris pv. campestris in the field and greenhouse. Phytopathology 85, 1296-1300.

Cartea, M. E., Francisco, M., Soengas, P., and Velasco, P. (2011b). Phenolic compounds in Brassica vegetables. Molecules 16, 251-280. doi: 10.3390/ molecules 16010251

Cartea, M. E., Lema, M., Francisco, M., and Velasco, P. (2011a). "Basic information on vegetable Brassica crops," in Genetics, Genomics and Breeding of Vegetable Brassicas, eds J. Sadowski and K. Chittaranjan (Enfield, NH: Science Publishers), $1-34$.

Caranta, C., Lefebvre, V., and Palloix, A. (1997). Polygenic resistance of pepper to potyviruses consists of a combination of isolate-specific and broad-spectrum quantitative trait loci. Mol. Plant Microbe Interact. 10, 872-878. doi: 10.1094/ mpmi.1997.10.7.872

Castro-Moretti, F. R., Gentzel, I. N., Mackey, D., and Alonso, A. P. (2020). Metabolomics as an emerging tool for the study of plant-pathogen interactions. Metabolites 10:52. doi: 10.3390/metabo10020052

Chalhoub, B., Denoeud, F., Liu, S., Parkin, I. A., Tang, H., Wang, X., et al. (2014). Early allopolyploid evolution in the post-Neolithic Brassica napus oilseed genome. Science 345, 950-953. doi: 10.1126/science.1253435

Chan, J. W. Y. F., and Goodwin, P. H. (1999). The molecular genetics of virulence of Xanthomonas campestris. Biotechnol. Adv. 17, 489-508. doi: 10.1016/s07349750(99)00025-7

Chatterjee, S., Mukherjee, D., Patil, S. B., Kansal, S., Kanwar, H. S., and Choudhuri, P. (2018). Screening of cauliflower genotypes against economically important diseases and disorder in mid hilly regions of Himachal Pradesh. Int. J. Pure Appl. Biosci. 6, 774-778. doi: 10.18782/2320-7051.6277 
Cheng, F., Liu, S., Wu, J., Fang, L., Sun, S., Liu, B., et al. (2011). BRAD, the genetics and genomics database for Brassica plants. BMC Plant Biol. 11:136. doi: 10.1186/1471-2229-11-136

Chevalier, F. (2010). Highlights on the capacities of "Gel-based" proteomics. Proteome Sci. 8:23. doi: 10.1186/1477-5956-8-23

Chini, A., Fonseca, S., Fernandez, G., Adie, B., Chico, J. M., Lorenzo, O., et al. (2007). The JAZ family of repressors is the missing link in jasmonate signalling. Nature 448, 666-671. doi: 10.1038/nature06006

Choi, H.-K. (2019). Translational genomics and multi-omics integrated approaches as a useful strategy for crop breeding. Genes Genomics 41, 133-146. doi: 10 . 1007/s13258-018-0751-8

Collard, B. C. Y., and Mackill, D. J. (2008). Marker-assisted selection: an approach for precision plant breeding in the twenty-first century. Philos. Trans. R. Soc. B 363, 557-572. doi: 10.1098/rstb.2007.2170

Collard, B. C. Y., Jahufer, M. Z. Z., Brouwer, J. B., and Pang, E. C. K. (2005). An introduction to markers, quantitative trait loci (QTL) mapping and markerassisted selection for crop improvement: the basic concepts. Euphytica 142, 169-196.

Costa, J., Villeth, G., Paulino, L., Santos, M., and Mehta, A. (2014). Identification of Brassica oleracea proteins during early infection by Xanthomonas campestris pv. campestris. BMC Proc. 8:97. doi: 10.1186/1753-6561-8-s4-Pp97

Crandall, S. G., Gold, K. M., Jiménez-Gasco, M. D. M., Filgueiras, C. C., and Willett, D. S. (2020). A multi-omics approach to solving problems in plant disease ecology. PLoS One 15:e0237975. doi: 10.1371/journal.pone.0237975

Cruz, J., Tenreiro, R., and Cruz, L. (2017). Assessment of diversity of Xanthomonas campestris pathovars affecting cruciferous plants in Portugal and disclosure of two novel X. campestris pv. campestris races. J. Plant Pathol. 99, 403-414. doi: 10.4454/jpp.v99i2.3890

Cvikrová, M., Malá, J., Hrubcová, M., and Eder, J. (2006). Soluble and cell wallbound phenolics and lignin in Ascocalyx abietina infected Norway spruces. Plant Sci. 170, 563-570.

da Silva, L. R., da Silva, R. C. D., Cardoso, A. F., de Mello Pelá, G., and Carvalho, D. D. C. (2015). Reaction of cauliflower genotypes to black rot of crucifers. Plant Pathology J. 31:181. doi: 10.5423/PPJ.OA.01.2015.0013

Dangl, J. L., and Jones, J. D. G. (2001). Plant pathogens and integrated defence responses to infection. Nature 411, 826-833. doi: 10.1038/35081161

Debieu, M., Huard-Chauveau, C., Genissel, A., Roux, F., and Roby, D. (2016). Quantitative disease resistance to the bacterial pathogen Xanthomonas campestris involves an Arabidopsis immune receptor pair and a gene of unknown function. Mol. Plant Pathol. 17, 510-520. doi: 10.1111/mpp.12298

Desclos-Theveniau, M., Arnaud, D., Huang, T.-Y., Lin, G. J.-C., Chen, W.-Y., Lin, Y.-C., et al. (2012). The Arabidopsis lectin receptor kinase LecRK-V. 5 represses stomatal immunity induced by Pseudomonas syringae pv. tomato DC3000. PLoS Pathog. 8:e1002513. doi: 10.1371/journal.ppat.1002513

Dey, S. S., Sharma, K., Dey, R. B., Kumar, G. M. S., Singh, D., Kumar, R., et al. (2015). Inter specific hybridization (Brassica carinata $\times$ Brassica oleracea) for introgression of black rot resistance genes into Indian cauliflower (B. oleracea var. botrytis L.). Euphytica 204, 149-162. doi: 10.1007/s10681-015-1352-0

Dhar, S., and Singh, D. (2014). Performance of cauliflower genotypes for yield and resistance against black rot (Xanthomonas campestris pv. campestris). Indian J. Hortic. 71, 197-201.

Dickson, M. D., and Hunter, J. E. (1987). Inheritance of resistance in cabbage seedlings to black rot. HortScience 22, 108-109.

Dixon, R. A., Achnine, L., Kota, P., Liu, C. J., Reddy, M. S., and Wang, L. (2002). The phenylpropanoid pathway and plant defence-a genomics perspective. Mol. Plant Pathol. 3, 371-390. doi: 10.1046/j.1364-3703.2002.00131.x

Dossa, K., Diouf, D., Wang, L., Wei, X., Zhang, Y., Niang, M., et al. (2017). The emerging oilseed crop Sesamum indicum enters the "Omics" era. Front Plant Sci. 8:1154. doi: 10.3389/fpls.2017.01154

Doullah, M., Mohsin, G. M., Ishikawa, K., Hori, H., and Okazaki, K. (2011). Construction of a linkage map and QTL analysis for black rot resistance in Brassica oleracea L. Int. J. Nat. Sci. 1, 1-6. doi: 10.3329/ijns.v1i1.8591

El-Metwally, S., Ouda, O. M., and Helmy, M. (2014). Next Generation Sequencing Technologies and Challenges in Sequence Assembly. Springer Briefs in Systems Biology. New York, NY: Springer, doi: 10.1007/978-1-4939-0715-1

Eldakak, M., Milad, S. I., Nawar, A. I., and Rohila, J. S. (2013). Proteomics: A biotechnology tool for crop improvement. Front. Plant Sci. 4:35. doi: 10.3389/ fpls.2013.00035
Ellis, J. G., Lagudah, E. S., Spielmeyer, W., and Dodds, P. N. (2014). The past, present and future of breeding rust resistant wheat. Front. Plant Sci. 5:641. doi: $10.3389 /$ fpls.2014.00641

Emon, J. M. V. (2016). The omics revolution in agricultural research. J. Agric. Food Chem. 64, 36-44. doi: 10.1021/acs.jafc.5b04515

Fahey, J. W., Zalcmann, A. T., and Talalay, P. (2001). The chemical diversity and distribution of glucosinolates and isothiocyanates among plants. Phytochemistry 56, 5-51. doi: 10.1016/s0031-9422(00)00316-2

FAOSTAT (2019). Food and Agriculture Organization of the United Nations. Available online at: https://faostat.fao.org (accessed September 15, 2021).

Fang, C., and Luo, J. (2019). Metabolic GWAS-based dissection of genetic bases underlying the diversity of plant metabolism. Plant J. 97, 91-100. doi: 10.1111/ tpj. 14097

Fargier, E., and Manceau, C. (2007). Pathogenicity assays restrict the species Xanthomonas campestris into three pathovars and reveal nine races within X. campestris pv. campestris. Plant Pathol. 56, 805-818. doi: 10.1111/j.13653059.2007.01648.x

Fekih, R., Takagi, H., Tamiru, M., Abe, A., Natsume, S., Yaegashi, H., et al. (2013). MutMap+: genetic mapping and mutant identification without crossing in rice. PLoS One 8:e68529. doi: 10.1371/journal.pone.0068529

Flor, H. H. (1971). Current status of the gene-for-gene concept. Annu. Rev. Phytopathol. 9, 275-296.

French, E., Kim, B. S., and Iyer-Pascuzzi, A. S. (2016). Mechanisms of quantitative disease resistance in plants. Semin. Dev. Biol. 56, 201-208. doi: 10.1016/j. semcdb.2016.05.015

Garman, H. (1894). A bacterial disease of cabbage. Ky. Agr. Exp. Stn. Rep. 3, 43-46. Gay, P. A., and Tuzun, S. (2000). Involvement of a novel peroxidase isozyme and lignification in hydathodes in resistance to black rot disease in cabbage. Can. J. Bot. 78, 1144-1149. doi: 10.1139/b00-086

Giamoustaris, A., and Mithen, R. (1995). The effect of modifying the glucosinolate content of leaves of oilseed rape (Brassica napus ssp. oleifera) on its interaction with specialist and generalist pests. Ann. Appl. Biol. 126, 347-363. doi: 10.1111/ j.1744-7348.1995.tb05371.x

Golicz, A. A., Bayer, P. E., Barker, G. C., Edger, P. P., Kim, H., Martinez, P. A., et al. (2016). The pangenome of an agronomically important crop plant Brassica oleracea. Nat. Commun. 7:13390. doi: 10.1038/ncomms 13390

Griesbach, E., Löptien, H., and Miersch, U. (2003). Resistance to Xanthomonas campestris pv. campestris (Pammel) Dowson in cabbage Brassica oleracea L. J. Plant Dis. Prot. 110, 461-475.

Griffiths, P. D., Marek, L. F., and Robertson, L. D. (2009). Identification of crucifer accessions from the NC-7 and NE-9 plant introduction collections that are resistant to black rot (Xanthomonas campestris pv. campestris) races 1 and 4 . HortScience 44, 284-288. doi: 10.21273/HORTSCI.44.2.284

Griffiths, W. J., Koal, T., Wang, Y., Kohl, M., Enot, D. P., and Deigner, H. P. (2010). Targeted metabolomics for biomarker discovery. Angew. Chem. Int. Ed. Engl. 49, 5426-5445. doi: 10.1002/anie.200905579

Gu, Y., Mao, Y. W., Wang, C. G., Zhao, Q. C., Sun, D. L., and Song, W. Q. (2008). Cloning of differential expression fragments in cauliflower after Xanthomonas campestris inoculation. Biol. Plant 52, 462-468. doi: 10.1007/s10535-0080091-7

Gu, Y., Qiu, Z., Cheng, N., Chen, C., Hei, Z., and Li, X. (2019). Identification of potential mechanism and hub genes for neuropathic pain by expressionbased genome-wide association study. J. Cell Biochem. 120, 4912-4923. doi: $10.1002 /$ jcb. 27766

Gudesblat, G. E., Torres, P. S., and Vojnov, A. A. (2009). Xanthomonas campestris overcomes Arabidopsis stomatal innate immunity through a DSF cell-to-cell signal-regulated virulence factor. Plant physiol. 149, 1017-1027. doi: 10.1104/ pp.108.126870

Guillemin, N., Horvatic, A., Kuleš, J., Galan, A., Mrljak, V., and Bhide, M. (2016). Omics approaches to probe markers of disease resistance in animal sciences. Mol. Biosyst. 12, 2036-2046. doi: 10.1039/c6mb00 $220 \mathrm{j}$

Guo, N., Wang, S., Gao, L., Liu, Y., Wang, X., Lai, E., et al. (2021). Genome sequencing sheds light on the contribution of structural variants to Brassica oleracea diversification. BMC Biol. 19:93. doi: 10.1186/s12915-021-01031-2

Gupta, U. S. (2011). Brassica Vegetables, What's New About Crop Plants, 1st Edn. Enfield, NH: Science Publishers, 378-402. 
Hansen, L. N., and Earle, E. D. (1995). Transfer of resistance to Xanthomonas campestris pv campestris into Brassica oleracea $\mathrm{L}$. by protoplast fusion. Theor. Appl. Genet. 91, 1293-1300. doi: 10.1007/BF00220944

Hasin, Y., Seldin, M., and Lusis, A. (2017). Multi-omics approaches to disease. Genome Biol. 18:83. doi: 10.1186/s13059-017-1215-1

He, Y.-Q., Zhang, L., Jiang, B.-L., Zhang, Z.-C., Xu, R.-Q., Tang, D.-J., et al. (2007). Comparative and functional genomics reveals genetic diversity and determinants of host specificity among reference strains and a large collection of Chinese isolates of the phytopathogen Xanthomonas campestris pv. campestris. Genome Biol. 8:R218. doi: 10.1186/gb-2007-8-10-r218

He, Y.-W., and Zhang, L.-H. (2008). Quorum sensing and virulence regulation in Xanthomonas campestris. FEMS microbiol Rev. 32, 842-857. doi: 10.1111/j. 1574-6976.2008.00120.x

Helmy, M., Sugiyama, N., Tomita, M., and Ishihama, Y. (2012). Mass spectrum sequential subtraction speeds up searching large peptide MS/MS spectra datasets against large nucleotide databases for proteogenomics. Genes Cells 17, 633-644. doi: 10.1111/j.1365-2443.2012.01615.x

Helmy, M., Tomita, M., and Ishihama, Y. (2011). OryzaPG-DB: rice proteome database based on shotgun proteogenomics. BMC Plant Biol. 11:63. doi: 10. 1186/1471-2229-11-63

Hiruma, K., Fukunaga, S., Bednarek, P., Piślewska-Bednarek, M., Watanabe, S., Narusaka, Y., et al. (2013). Glutathione and tryptophan metabolism are required for Arabidopsis immunity during the hypersensitive response to hemibiotrophs. Proc. Natl. Acad. Sci. U.S.A. 110, 9589-9594. doi: 10.1073/pnas. 1305745110

Ho, Y.-P., Tan, C. M., Li, M.-Y., Lin, H., Deng, W.-L., and Yang, J.-Y. (2013). The AvrB_AvrC domain of AvrXccC of Xanthomonas campestris pv. campestris is required to elicit plant defense responses and manipulate $\mathrm{ABA}$ homeostasis. Mol. Plant Microbe Interact. 26, 419-430. doi: 10.1094/MPMI-06-120164-R

Horsfall, J. G., and Cowling, E. B. (1978). "Pathometry: the measurement of plant disease," in Plant Disease: An Advanced Treatise, Vol. II, eds J. G. Horsfall and E. B. Cowling (New York, NY: Academic Press), 119-136.

Houle, D., Govindaraju, D. R., and Omholt, S. (2010). Phenomics: the next challenge. Nat. Rev. Genet. 11, 855-866. doi: 10.1038/nrg2897

Huard-Chauveau, C., Perchepied, L., Debieu, M., Rivas, S., Kroj, T., Kars, I., et al. (2013). An atypical kinase under balancing selection confers broad-spectrum disease resistance in Arabidopsis. PLoS Genet. 9:e1003766. doi: 10.1371/journal. pgen.1003766

Iglesias-Bernabé, L., Madloo, P., Rodríguez, V. M., Francisco, M., and Soengas, P. (2019). Dissecting quantitative resistance to Xanthomonas campestris pv. campestris in leaves of Brassica oleracea by QTL analysis. Sci. Rep. 9:2015. doi: 10.1038/s41598-019-38527-5

Ignatov, A., Kuginuki, Y., and Hida, K. I (1998). Race-specific reaction of resistance to black rot in Brassica oleracea. Eur. J. Plant Pathol. 104, 821-827. doi: 10.1023/ A:1008642829156

Ignatov, A. N., Kuginuki, Y., Suprunova, T. P., Pozmogova, G. E., Seitova, A. M., Dorokhov, D. B., et al. (2000). RAPD markers linked to locus controlling resistance for race 4 of the black rot causative agent, Xanthomonas campestris pv. Campestris (Pamm.) Dow. in Brassica rapa L. Russ. J. Genet. 36, 281-283.

Islam, M. T., Lee, B. R., Das, P. R., La, V. H., Jung, H. I., and Kim, T. H. (2018). Characterization of p-Coumaric acid-induced soluble and cell wallbound phenolic metabolites in relation to disease resistance to Xanthomonas campestris pv. campestris in Chinese cabbage. Plant Physiol. Biochem. 125, 172-177. doi: 10.1016/j.plaphy.2018.02.012

Islam, M. T., Lee, B. R., La, V. H., Bae, D. W., Jung, W. J., and Kim, T. H. (2021). Label-free quantitative proteomics analysis in susceptible and resistant Brassica napus cultivars infected with Xanthomonas campestris pv. campestris. Microorganisms 9:253. doi: 10.3390/microorganisms 9020253

Islam, M. T., Lee, B. R., La, V. H., Lee, H., Jung, W. J., Bae, D. W., et al. (2019a). p-Coumaric acid induces jasmonic acid-mediated phenolic accumulation and resistance to black rot disease in Brassica napus. Physiol. Mol. Plant Pathol. 106, 270-275. doi: 10.1016/j.pmpp.2019.04.001

Islam, M. T., Lee, B. R., Park, S. H., La, V. H., Bae, D. W., and Kim, T. H. (2017). Cultivar variation in hormonal balance is a significant determinant of disease susceptibility to Xanthomonas campestris pv. campestris in Brassica napus. Front. Plant Sci. 8:2121. doi: 10.3389/fpls.2017. 02121
Islam, M. T., Lee, B. R., Park, S. H., La, V. H., Jung, W. J., Bae, D. W., et al. (2019b). Hormonal regulations in soluble and cell-wall bound phenolic accumulation in two cultivars of Brassica napus contrasting susceptibility to Xanthomonas campestris pv. campestris. Plant Sci. 285, 132-140. doi: 10.1016/j.plantsci.2019. 05.010

Islam, W., Islam, S. U., Qasim, M., and Wang, L. (2017). Host-Pathogen interactions modulated by small RNAs. RNA Biol. 14, 891-904.

Izzah, N. K., Lee, J., Jayakodi, M., Perumal, S., Jin, M., Park, B. S., et al. (2014). Transcriptome sequencing of two parental lines of cabbage (Brassica oleracea $\mathrm{L}$. var. capitata L.) and construction of an EST-based genetic map. BMC Genomics 15:149. doi: 10.1186/1471-2164-15-149

Jain, M., Olsen, H. E., Paten, B., and Akeson, M. (2016). The Oxford Nanopore MinION: delivery of nanopore sequencing to the genomics community. Genome Biol. 17:239. doi: 10.1186/s13059-016-1103-0

Jamwal, R. S., and Sharma, P. P. (1986). Inheritance of resistance to black rot (Xanthomonas campestris pv. campestris) in cauliflower (Brassica oleracea var. botrytis). Euphytica 35, 941-943. doi: 10.1007/BF00028603

Jensen, B. D., Massomo, S. M. S., Swai, I. S., Hockenhull, J., and Andersen, S. B. (2005). Field evaluation for resistance to the black rot pathogen Xanthomonas campestris pv. campestris in cabbage (Brassica oleracea). Eur. J. Plant Pathol. 113, 297-308. doi: 10.1007/s10658-005-2799-y

Jiang, H., Song, W., Li, A., Yang, X., and Sun, D. (2011). Identification of genes differentially expressed in cauliflower associated with resistance to Xanthomonas campestris pv. campestris. Mol. Biol. Rep. 38, 621-629. doi: 10. 1007/s11033-010-0148-5

Jin, H., Sun, Y., Yang, Q., Chao, Y., Kang, J., Jin, H., et al. (2010). Screening of genes induced by salt stress from Alfalfa. Mol. Biol. Rep. 37, 745-753. doi: 10.1007/s11033-009-9590-7

Jorge, T. F., Rodrigues, J. A., Caldana, C., Schmidt, R., Van Dongen, J. T., ThomasOates, J., et al. (2016). Mass spectrometry-based plant metabolomics: metabolite responses to abiotic stress. Mass Spectrom Rev. 35, 620-649. doi: 10.1002/mas. 21449

Joshi, R. K., and Nayak, S. (2011). Functional characterization and signal transduction ability of nucleotide-binding site-leucine-rich repeat resistance genes in plants. Genet. Mol. Res. 10, 2637-2652.

Kalia, P., Saha, P., and Ray, S. (2017). Development of RAPD and ISSR derived SCAR markers linked to XcalBo gene conferring resistance to black rot disease in cauliflower (Brassica oleracea var. botrytis L.). Euphytica 213, 232. doi: 10. 1007/s10681-017-2025-y

Kamo, M., Kawakami, T., Miyatake, N., and Tsugita, A. (1995). Separation and characterization of Arabidopsis thaliana proteins by two-dimensional gel electrophoresis. Electrophoresis 16, 423-430. doi: 10.1002/elps.1150160169

Kamoun, S., Kadmar, H. V., Tola, E., and Kado, C. I. (1992). Incompatible interaction between crucifers and Xanthomonas campestris involve a vascular hypersensitive response: role of the hrpX locus. Mol. Plant Microbe Interact. 5, $22-33$.

Kapusta-Duch, J., Kopec, A., Piatkowska, E., Borczak, B., and Leszczynska, T. (2012). The beneficial effects of Brassica vegetables on human health. Rocz Panstw Zakl Hig. 63, 389-395.

Kashyap, P. L., and Dhiman, J. S. (2010). Eco-friendly strategies to suppress the development of Alternaria blight and black rot of cauliflower. Acad. J. Plant Sci. 3, 140-146.

Kathju, S., Satish, L., Rabik, C., Rupert, T., Oswald, D., Johnson, S., et al. (2006). Identification of differentially expressed genes in scarless wound healing utilizing polymerase chain reaction-suppression subtractive hybridization. Wound Repair Regen. 14, 413-420. doi: 10.1111/j.1743-6109.2006.00140

Kaur, R., Shivani, Saxena, B., Kanwar, H. S., Dohroo, N. P., Majeed, S., et al. (2009). Detecting RAPD markers associated with black rot resistance in cabbage (Brassica oleracea var. capitata). Fruit. Veg. Cereal Sci. Biotechnol. 3, 12-15.

Kell, D. B., and Oliver, S. G. (2016). The metabolome 18 years on: a concept comes of age. Metabolomics 12, 1-8. doi: 10.1007/s11306-016-1108-4

Khan, A. W., Garg, V., Roorkiwal, M., Golicz, A. A., Edwards, D., and Varshney, R. K. (2020). Super-pangenome by integrating the wild side of a species for accelerated crop improvement. Trends Plant Sci. 25, 148-158. doi: 10.1016/j. tplants.2019.10.012

Khandagale, K., Krishna, R., Roylawar, P., Ade, A. B., Benke, A., Shinde, B., et al. (2020). Omics approaches in Allium research: progress and way ahead. PeerJ 8:e9824. doi: 10.7717/peerj.9824 
Kifuji, Y., Hanzawa, H., Terasawa, Y., Ashutosh, and Nishio, T. (2013). QTL analysis of black rot resistance in cabbage using newly developed EST-SNP markers. Euphytica 190, 289-295. doi: 10.1007/s10681-012-0847-1

Kim, T.-H., Hauser, F., Ha, T., Xue, S., Böhmer, M., Nishimura, N., et al. (2011). Chemical genetics reveals negative regulation of abscisic acid signaling by a plant immune response pathway. Curr. Biol. 21, 990-997. doi: 10.1016/j.cub. 2011.04.045

Kliebenstein, D. J. (2004). Secondary metabolites and plant/environment interactions: a view through Arabidopsis thaliana tinged glasses. Plant Cell Environ. 27, 675-684. doi: 10.1111/j.1365-3040.2004.01180.x

Klüsener, B., Young, J. J., Murata, Y., Allen, G. J., Mori, I. C., Hugouvieux, V., et al. (2002). Convergence of calcium signaling pathways of pathogenic elicitors and abscisic acid in Arabidopsis guard cells. Plant Physiol. 130, 2152-2163. doi: $10.1104 /$ pp. 012187

Komatsu, S., and Tanaka, N. (2005). Rice proteome analysis: a step toward functional analysis of the rice genome. Proteomics 5, 938-949. doi: 10.1002/ pmic. 200401040

Komatsu, S., Kamal, A. H. M., and Hossain, Z. (2014). Wheat proteomics: proteome modulation and abiotic stress acclimation. Front. Plant Sci. 5:684. doi: 10.3389/fpls.2014.00684

Kong, C., Chen, G., Yang, L., Zhuang, M., Zhang, Y., Wang, Y., et al. (2021). Germplasm screening and inheritance analysis of resistance to cabbage black rot in a worldwide collection of cabbage (Brassica oleracea var. capitata) resources. Sci. Hortic 288:110234. doi: 10.1016/j.scienta.2021.110234

Kruszka, K., Pieczynski, M., Windels, D., Bielewicz, D., Jarmolowski, A., Szweykowska-Kulinska, Z., et al. (2012). Role of microRNAs and other sRNAs of plants in their changing environments. J. Plant Physiol. 169, 1664-1672. doi: 10.1016/j.jplph.2012.03.009

Lee, J., Izzah, N. K., Jayakodi, M., Perumal, S., Joh, H. J., Lee, H. J., et al. (2015). Genome-wide SNP identification and QTL mapping for black rot resistance in cabbage. BMC Plant Biol. 15:32. doi: 10.1186/s12870-015-0424-6

Lee, Y. H., and Hong, J. K. (2015). Differential defence responses of susceptible and resistant kimchi cabbage cultivars to anthracnose, black spot and black rot diseases. Plant Pathol. 64, 406-415. doi: 10.1111/ppa.12262

Lema, M., Cartea, M. E., Francisco, M., Velasco, P., and Soengas, P. (2015). Screening for resistance to black rot in a Spanish collection of Brassica rapa. Plant Breed. 134, 551-556. doi: 10.1111/pbr.12293

Lema, M., Cartea, M. E., Sotelo, T., Velasco, P., and Soengas, P. (2012a). Discrimination of Xanthomonas campestris pv. campestris races among strains from northwestern Spain by Brassica spp. genotypes and rep-PCR. Eur. J. Plant Pathol. 133, 159-169. doi: 10.1007/s10658-011-9929-5

Lema, M., Velasco, P., Soengas, P., Francisco, M., and Cartea, M. E. (2012b). Screening for resistance to black rot in Brassica oleracea crops. Plant Breed. 131, 607-613. doi: 10.1111/j.1439-0523.2012.01974.x

Li, G., Riaz, A., Goyal, S., Abel, S., and Quiros, C. F. (2001). Inheritance of three major genes involved in the synthesis of aliphatic glucosinolates in Brassica oleracea. J Am Soc Hort. Sci. 126, 427-431. doi: 10.21273/JASHS.126.4. 427

Li, Z. K., Luo, L. J., Mei, H. W., Paterson, A. H., Zhao, X. H., Zhong, D. B., et al. (1999). A "defeated" rice resistance gene acts as a QTL against a virulent strain of Xanthomonas oryzae pv. oryzae. Mol. Gen. Genet. 261, 58-63. doi: 10.1007/s004380050941

Liao, C. T., Liu, Y. F., Chiang, Y. C., Lo, H. H., Du, S. C., Hsu, P. C., et al. (2016). Functional characterization and transcriptome analysis reveal multiple roles for prc in the pathogenicity of the black rot pathogen Xanthomonas campestris pv. campestris. Res. Microbiol. 167, 299-312. doi: 10.1016/j.resmic.2016.01.002

Liégard, B., Baillet, V., Etcheverry, M., Joseph, E., Lariagon, C., Lemoine, J., et al. (2019). Quantitative resistance to clubroot infection mediated by transgenerational epigenetic variation in Arabidopsis. New Phytol. 222, 468479. doi: 10.1111/nph.15579

Liu, H.-W., Liang, C.-Q., Liu, P.-F., Luo, L. X., and Li, J. Q. (2015). Quantitative proteomics identifies 38 proteins that are differentially expressed in cucumber in response to cucumber green mottle mosaic virus infection. Virol. J. 12:216. doi: 10.1186/s12985-015-0442-x

Liu, S., Liu, Y., Yang, X., Tong, C., Edwards, D., Parkin, I. A., et al. (2014). The Brassica oleracea genome reveals the asymmetrical evolution of polyploid genomes. Nat. Commun. 5:3930. doi: 10.1038/ncomms4930
Liu, X., and Locasale, J. W. (2017). Metabolomics: a primer. Trends Biochem Sci. 42, 274-284. doi: 10.1016/j.tibs.2017.01.004

Liu, X., Zhao, C., Yang, L., Zhang, Y., Wang, Y., Fang, Z., et al. (2020). Genomewide identification, expression erofile of the TIFY gene family in Brassica oleracea var. capitata, and their divergent response to various pathogen infections and phytohormone treatments. Genes (Basel) 11:127. doi: 10.3390/ genes 11020127

Lodha, T. D., Hembram, P., Tep, N., and Basak, J. (2013). Proteomics: a successful approach to understand the molecular mechanism of plant-pathogen interaction. Am. J. Plant Sci. 4, 1212-1226. doi: 10.4236/ajps.2013.46149

Luo, Y., Lv, G. L., Wu, W. T., Chen, S. N., and Cheng, Z. Q. (2010). Analysis of genome expression in the response of Oryza granulata to Xanthomonas oryzae pv oryzae. Mol. Biol. Rep. 37:875. doi: 10.1007/s11033-009-9694-0

Lv, H., Wang, Y., Han, F., Ji, J., Fang, Z., Zhuang, M., et al. (2020). A high-quality reference genome for cabbage obtained with SMRT reveals novel genomic features and evolutionary characteristics. Sci. Rep. 10:12394. doi: 10.1038/ s41598-020-69389-x

Madloo, P., Lema, M., Francisco, M., and Soengas, P. (2019). Role of major glucosinolates in the defense of kale against Sclerotinia sclerotiorum and Xanthomonas campestris pv. campestris. Phytopathology 109, 1246-1256. doi: 10.1094/PHYTO-09-18-0340-R

Mamun, M., Islam, M., Lee, B. R., La, V. H., Bae, D. W., and Kim, T. H. (2020). Genotypic variation in resistance gene-mediated calcium signaling and hormonal signaling involved in effector-triggered immunity or disease susceptibility in the Xanthomonas campestris pv. campestris-Brassica napus pathosystem. Plants 9:303. doi: 10.3390/plants9030303

Manici, L. M., Lazzeri, L., and Palmieri, S. (1997). In vitro fungitoxic activity of some glucosinolates and their enzyme-derived products toward plant pathogenic fungi. J. Agri. Food Chem. 45, 2768-2773. doi: 10.1021/jf9608635

Mann, M., and Jensen, O. N. (2003). Proteomic analysis of post-translational modifications. Nat. Biotechnol. 21, 255-261. doi: 10.1038/nbt0303-255

Martínez-Medina, A., Fernandez, I., Lok, G. B., Pozo, M. J., Pieterse, C. M. J., and Van Wees, S. C. M. (2017). Shifting from priming of salicylic acid-to jasmonic acid-regulated defences by Trichoderma protects tomato against the root knot nematode Meloidogyne incognita. New Phytol. 213, 1363-1377. doi: $10.1111 /$ nph.14251

McGettigan, P. A. (2013). Transcriptomics in the RNA-seq era. Curr. Opin. Chem. Biol. 17, 4-11. doi: 10.1016/j.cbpa.2012.12.008

Melotto, M., Mecey, C., Niu, Y., Chung, H. S., Katsir, L., Yao, J., et al. (2008). A critical role of two positively charged amino acids in the Jas motif of Arabidopsis JAZ proteins in mediating coronatine-and jasmonoyl isoleucinedependent interactions with the COI1 F-box protein. Plant J. 55, 979-988. doi: 10.1111/j.1365-313X.2008.03566.x

Mulema, J. M. K., Vicente, J. G., Pink, D. A. C., Jackson, A., Chacha, D. O., Wasilwa, L., et al. (2012). Characterization of isolates that cause black rot of crucifers in East Africa. Eur. J. Plant Pathol. 133, 427-438. doi: 10.1007/s10658-011-9916-x

Mundt, C. C. (2014). Durable resistance: a key to sustainable management of pathogens and pests. Infect. Genet. Evol. 27, 446-455. doi: 10.1016/j.meegid. 2014.01.011

Nakagami, H., Sugiyama, N., Ishihama, Y., and Shirasu, K. (2012). Shotguns in the front line: phosphoproteomics in plants. Plant Cell Physiol. 53, 118-124. doi: $10.1093 / \mathrm{pcp} / \mathrm{pcr} 148$

Neik, T. X., Amas, J., Barbetti, M., Edwards, D., and Batley, J. (2020). Understanding host-pathogen interactions in Brassica napus in the omics era. Plants 9:1336. doi: 10.3390/plants9101336

Niks, R. E., Qi, X. Q., and Marcel, T. C. (2015). "Quantitative resistance to biotrophic filamentous plant pathogens: concepts, misconceptions and mechanisms," in Annual Review of Phytopathology, ed. N. K. VanAlfen (PaloAlto, CA: Annual Reviews), 445-470.

O'Callaghan, K. J., Stone, P. J., Hu, X., Griffiths, D. W., Davey, M. R., and Cocking, E. C. (2000). Effects of glucosinolates and flavonoids on colonization of the roots of Brassica napus by Azorhizobium caulinodans ORS571. Appl. Environ. Microbiol. 66, 2185-2191. doi: 10.1128/AEM.66.5.2185-2191.2000

Palloix, A., Ayme, V., and Moury, B. (2009). Durability of plant major resistance genes to pathogens depends on the genetic background, experimental evidence and consequences for breeding strategies. New Phytol. 183, 190-199. doi: 10. 1111/j.1469-8137.2009.02827.x 
Pandey, K. K., Pandey, P. K., and Singh, B. (2003). Artificial screening for black rot resistance based on different disease parameter in early cauliflower. Mycobiology 31, 173-178. doi: 10.4489/MYCO.2003.31.3.173

Pandey, S. C., Naik, G., Kishun, R., and Sridhar, T. S. (1995). "Breeding resistant varieties in cauliflower and cabbage," in Agro-Ecosystems Management, eds S. K. Mukhopadhyay, M. K. Das Gupta, P. K. Gupta, D. K. Majumdar, and N. C. Mandal (Pali-Siksha Bhawan: Sriniketan), 144-149.

Parkin, I. A. P., Koh, C., Tang, H., Robinson, S. J., Kagale, S., Clarke, W. E., et al. (2014). Transcriptome and methylome profiling reveals relics of genome dominance in the mesopolyploid Brassica oleracea. Genome Biol. 15:R77. doi: 10.1186/gb-2014-15-6-r77

Patel, P. N., Triwdi, B. M., Rekhi, S. S., Town, P. A., and Rao, Y. P. (1970). Black Rot and Stump rot Epidemic in Cauliflower (Snowball) Seed Crops in India During 1968/69. FAO Plant Protection Bull. Rome: FAO.

Pathak, R. K., Baunthiyal, M., Pandey, D., and Kumar, A. (2018). Augmentation of crop productivity through interventions of omics technologies in India: challenges and opportunities. 3 Biotech 8:454. doi: 10.1007/s13205-018-1473-y

Pathak, R. K., Baunthiyal, M., Pandey, N., Pandey, D., and Kumar, A. (2017). Modeling of the jasmonate signaling pathway in Arabidopsis thaliana with respect to pathophysiology of Alternaria blight in Brassica. Sci Rep. 7:16790. doi: 10.1038/s41598-017-16884-3

Peng, H., Wang, K., Chen, Z., Cao, Y., Gao, Q., Li, Y., et al. (2020). MBKbase for rice: an integrated omics knowledgebase for molecular breeding in rice. Nucleic Acids Res. 48, D1085-D1092. doi: 10.1093/nar/gkz921

Peyraud, R., Mbengue, M., Barbacci, A., and Raffaele, S. (2019). Intercellular cooperation in a fungal plant pathogen facilitates host colonization. Proc. Natl. Acad. Sci.U.S.A. 116, 3193-3201. doi: 10.1073/pnas. 1811267116

Pieterse, C. M., Van Wees, S. C., Hoffland, E., van Pelt, J. A., and van Loon, L. C. (1996). Systemic resistance in Arabidopsis induced by biocontrol bacteria is independent of salicylic acid accumulation and pathogenesis-related gene expression. Plant Cell 8, 1225-1237. doi: 10.1105/tpc.8.8.1225

Poland, J., and Rutkoski, J. (2016). Advances and challenges in genomic selection for disease resistance. Annu. Rev. Phytopathol. 54, 79-98. doi: 10.1146/annurevphyto-080615-100056

Pomastowski, P., and Buszewski, B. (2014). Two-dimensional gel electrophoresis in the light of new developments. Trac Trend Anal. Chem. 53, 167-177. doi: 10.1016/j.trac.2013.09.010

Quirino, B. F., Candido, E. S., Campos, P. F., Franco, O. L., and Krüger, R. H. (2010). Proteomic approaches to study plant-pathogen interactions. Phytochemistry 71, 351-362. doi: 10.1016/j.phytochem.2009.11.005

Quiros, C. F., and Farnham, M. W. (2011). "The genetics of Brassica oleracea," in Genetics and Genomics of the Brassicaceae. Plant Genetics and Genomics: Crops and Models, Vol. 9, eds R. Schmidt and I. Bancroft (New York, NY: Springer), doi: 10.1007/978-1-4419-7118-0_9

Ragimekula, N., Varadarajula, N. N., Mallapuram, S. P., Gangimeni, G., Reddy, R. K., and Kondreddy, H. R. (2013). Marker assisted selection in disease resistance breeding. J. Plant Breed. Genet. 1, 90-109.

Rangkadilok, N., Nicolas, M. E., Bennett, R. N., Premier, R. R., Eagling, D. R., and Taylor, P. W. J. (2002). Developmental changes of sinigrin and glucoraphanin in three Braissica species (Brassica nigra, Brassica juncea and Brassica oleracea var. italica). Sci. Hortic. 96, 11-26. doi: 10.1016/s0304-4238(02)00 118-8

Renaut, J., Hausman, J. F., and Wisniewski, M. E. (2006). Proteomics and lowtemperature studies: bridging the gap between gene expression and metabolism. Physiol. Plant. 126, 97-109. doi: 10.1111/j.1399-3054.2005.00617.x

Ribaut, J. M., De Vicente, M. C., and Delannay, X. (2010). Molecular breeding in developing countries: challenges and perspectives. Curr. Opin. Plant Biol. 13, 213-218. doi: 10.1016/j.pbi.2009.12.011

Ribeiro, D. G., Cunha, G. C. R. D., Santos, C. D., Silva, L. P., Oliveira Neto, O. B. D., Labuto, L. B. D., et al. (2018). Brassica oleracea resistance-related proteins identified at an early stage of black rot disease. Physiol. Mol. Plant Pathol. 104, 9-14. doi: 10.1016/j.pmpp.2018.06.002

Roberts, R. J., Carneiro, M. O., and Schatz, M. C. (2013). The advantages of SMRT sequencing. Genome Biol. 14:405. doi: 10.1186/gb-2013-14-6-405

Rocherieux, J., Glory, P., Giboulot, A., Boury, S., Barbeyron, G., Thomas, G., et al. (2004). Isolate-specific and broad-spectrum QTLs are involved in the control of clubroot in Brassica oleracea. Theor. Appl. Genet. 108, 1555-1563. doi: $10.1007 / \mathrm{s} 00122-003-1580-\mathrm{x}$
Roohie, R. K., and Umesha, S. (2015). Identification of genes associated with black rot resistance in cabbage through suppression subtractive hybridization. 3 Biotech 5, 1089-1100. doi: 10.1007/s13205-015-0311-8

Roux, F., Noël, L., Rivas, S., and Roby, D. (2014). ZRK atypical kinases: emerging signaling components of plant immunity. New Phytol. 203, 713-716. doi: 10. $1111 /$ nph.12841

Rubel, M. H., Abuyusuf, M., Nath, U. K., Robin, A. H. K., Jung, H. J., Kim, H. T., et al. (2020). Glucosinolate profile and glucosinolate biosynthesis and breakdown gene expression manifested by black rot disease infection in cabbage. Plants 9:1121. doi: 10.3390/plants9091121

Rubio-Somoza, I., Cuperus, J. T., Weigel, D., and Carrington, J. C. (2009). Regulation and functional specialization of small RNA-target nodes during plant development. Curr. Opin. Plant Biol. 12, 622-627. doi: 10.1016/j.pbi.2009. 07.003

Sagi, M. S., Deokar, A. A., and Tar'an, B. (2017). Genetic analysis of NBS-LRR gene family in chickpea and their expression profiles in response to Ascochyta blight infection. Front. Plant Sci. 8:838. doi: 10.3389/fpls.2017.00838

Saha, P., Ghoshal, C., Saha, N. D., Verma, A., Srivastava, M., Kalia, P., et al. (2021). Marker-assisted pyramiding of downy mildew-resistant gene Ppa3 and black rot-resistant gene Xcalbo in popular early cauliflower variety pusa meghna. Front. Plant Sci. 12:603600. doi: 10.3389/fpls.2021.603600

Saha, P., Kalia, P., Sharma, M., and Singh, D. (2016). New source of black rot disease resistance in Brassica oleracea and genetic analysis of resistance. Euphytica 207, 35-48. doi: 10.1007/s10681-015-1524-y

Saha, P., Kalia, P., Sharma, P., and Sharma, T. R. (2014a). Race-specific genetics of resistance to black rot disease [Xanthomonas campestris pv. campestris $(X c c)$ (Pammel) Dowson] and the development of three random amplified polymorphic DNA markers in cauliflower. J. Hortic. Sci. Biotechnol. 89, 480486. doi: 10.1080/14620316.2014.11513109

Saha, P., Kalia, P., Sonah, H., Sharma, T. R., and Chevre, A. M. (2014b). Molecular mapping of black rot resistance locus Xcalbo on chromosome 3 in Indian cauliflower (Brassica oleracea var. botrytis L.). Plant Breed. 133, 268-274. doi: $10.1111 /$ pbr. 12152

Saharan, G. S. (1993). "Disease resistance," in Breeding Oilseed Brassicas, eds K. S. Labana, S. S. Banga, and S. K. Banga (Berlin: Springer), 181-205.

Santos, C., Maximiano, M. R., Ribeiro, D. G., Oliveira-Neto, O. B., Murad, A. M., Franco, O. L., et al. (2017). Differential accumulation of Xanthomonas campestris pv. campestris proteins during the interaction with the host plant: contributions of an in vivo system. Proteomic 17:1700086. doi: 10.1002/pmic. 201700086

Santos, C., Nogueira, F. C. S., Domont, G. B., Fontes, W., Prado, G. S., Habibi, P., et al. (2019). Proteomic analysis and functional validation of a Brassica oleracea endochitinase involved in resistance to Xanthomonas campestris. Front. Plant Sci. 10:414. doi: 10.3389/fpls.2019.00414

Santos, L. S., Maximiano, M. R., Megias, E., Pappas, M., Ribeiro, S. G., and Mehta, A. (2019). Quantitative expression of microRNAs in Brassica oleracea infected with Xanthomonas campestris pv. campestris. Mol. Biol. Rep. 46, 3523-3529. doi: 10.1007/s11033-019-04779-7

Schrimpe-Rutledge, A. C., Codreanu, S. G., Sherrod, S. D., and McLean, J. A. (2016). Untargeted metabolomics strategies-challenges and emerging directions. J. Am. Soc. Mass Spectrom. 27, 1897-1905. doi: 10.1007/s13361-0161469-y

Serra, B., Rosa, E., Iori, R., Barillari, J., Cardoso, A., Abreu, C., et al. (2002). In vitro activity of 2-phenylethyl glucosinolate, and its hydrolysis derivatives on the root-knot nematode Globodera rostochiensis (Woll.). Sci. Hortic. 92, 75-81. doi: 10.1016/s0304-4238(01)00277-1

Setia, R. C., and Setia, N. (2008). "The '-OMICS' technologies and crop improvement," in Crop Improvement: Strategies and Applications, eds R. C. Setia, H. Nayyar, and N. Setia (New Dehli: International Publishing House Pvt. Ltd), $1-18$.

Shao, S., Guo, T., and Aebersold, R. (2015). Mass spectrometry-based proteomic quest for diabetes biomarkers. Biochim. Biophys. Acta. 1854, 519-527. doi: 10.1016/j.bbapap.2014.12.012

Sharma, B. B., Kalia, P., Singh, D., and Sharma, T. R. (2017). Introgression of black rot resistance from Brassica carinata to cauliflower (Brassica oleracea botrytis group) through embryo rescue. Front. Plant Sci. 8:1255. doi: 10.3389/fpls.2017. 01255 
Sharma, B. B., Kalia, P., Yadava, D. K., Singh, D., and Sharma, T. R. (2016). Genetics and molecular mapping of black rot resistance locus Xcalbc on chromosome B7 in Ethiopian mustard (Brassica carinata A. Braun). PLoS One 11:e0152290. doi: 10.1371/journal.pone.0152290

Sharma, B. R., Dhiman, J. S., Thakur, J. C., Singh, A., and Bajaj, K. L. (1991). Multiple disease resistance in cauliflower. Adv. Hortic. Sci. 5, 30-34.

Sharma, B. R., Swarup, V., and Chatterjee, S. S. (1972). Inheritance of resistance to blackrot in cauliflower. Can. J. Genet. Cytol. 14, 363-370.

Sharma, B. R., Swarup, V., and Chatterjee, S. S. (1977). Resistance to black rot disease in cauliflower. Sci. Hortic. 7, 1-7.

Sharma, S. R., Kapoor, K. S., and Gill, H. S. (1995). Screening against sclerotinia rot (Sclerotinia sclerotiorum), downy mildew (Peronospora parasitica) and black rot (Xanthomonas campestris) in cauliflower (Brassica oleracea var botrytis subvar cauliflora). Indian J. Agric. Sci. 65, 916-918.

Sharma, S. K., Kohli, U. K., Kanwar, H. S., Kumar, S., and Kumar, S. (2003). Performance of newly introduced temperate cabbage and cauliflower germplasm against black rot and stalk rot diseases. Plant Dis. Res. 18, 90-91.

Sheng, X. G., Branca, F., Zhao, Z. Q., Wang, J.-S., Yu, H. F., Shen, Y. S., et al. (2020). Identification of black rot resistance in a wild Brassica species and its potential transferability to cauliflower. Agronomy 10:1400. doi: 10.3390/ agronomy10091400

Simard, M., Rioux, D., and Laflamme, G. (2001). Formation of ligno-suberized tissues in Jack pine resistant to the European race of Gremmeniella abietina. Phytopathology 91, 1128-1140.

Singh, A., Shukla, N., Kabadwal, B. C., Tewari, A. K., and Kumar, J. (2018). Review on plant-Trichoderma-pathogen interaction. Int. J. Curr. Microbiol. Appl. Sci. 7, 2382-2397. doi: 10.20546/ijcmas.2018.702.291

Singh, D., and Dhar, S. (2011). Bio-PCR based diagnosis of Xanthomonas campestris pathovars in black rot infected leaves of crucifers. Indian Phytopathol. 64, 506-516.

Singh, D., Dhar, S., and Yadava, D. K. (2011). Genetic and pathogenic variability of Indian strains of Xanthomonas campestris pv. campestris causing black rot disease in crucifers. Curr. Microbiol. 63, 551-560. doi: 10.1007/s00284-0110024-0

Singh, D., Rathaur, P. S., and Vicente, J. G. (2016). Characterization, genetic diversity and distribution of Xanthomonas campestris pv. campestris races causing black rot disease in cruciferous crops of India. Plant Pathol. 65, 1411-1418. doi: 10.1111/ppa.12508

Soengas, P., Hand, P., Vicente, J. G., Pole, J. M., and Pink, D. A. (2007). Identification of quantitative trait loci for resistance to Xanthomonas campestris pv. campestris in Brassica rapa. Theor. Appl. Genet. 114, 637-645. doi: 10.1007/ s00122-006-0464-2

Song, L., Tang, J., Yan, J., Zeng, A., Lv, S., Gao, B., et al. (2020). Transcriptomic analysis of resistant and susceptible cabbage lines reveals differential expressions and candidate genes involved in cabbage early responses to black rot. 3 Biotech 10:308. doi: 10.1007/s13205-020-02256-8

Srivastava, V., Obudulu, O., Bygdell, J., Löfstedt, T., Rydén, P., Nilsson, R., et al. (2013). OnPLS integration of transcriptomic, proteomic and metabolomic data shows multi-level oxidative stress responses in the cambium of transgenic hipIsuperoxide dismutase Populus plants. BMC Genomics 14:893. doi: 10.1186/ 1471-2164-14-893

Stall, R. E., Gottwald, T. R., Koizwni, Nt, and Schaad, N. C. (1993). "Xanthomonas," in Xanthomonas, eds J. G. Swing and E. L. Civerolo (London: Chapman \& Hall), 265-299.

Stotz, H. U., Sawada, Y., Shimada, Y., Hirai, M. Y., Sasaki, E., Krischke, M., et al. (2011). Role of camalexin, indole glucosinolates, and side chain modification of glucosinolate-derived isothiocyanates in defense of Arabidopsis against Sclerotinia sclerotiorum. Plant J. 67, 81-93. doi: 10.1111/j.1365-313X.2011. 04578.x

Su, J., Jiang, J., Zhang, F., Liu, Y., Ding, L., Chen, S., et al. (2019). Current achievements and future prospects in the genetic breeding of chrysanthemum: a review. Hortic. Res. 6:109. doi: 10.1038/s41438-019-0193-8

Sun, D., Wang, C., Zhang, X., Zhang, W., Jiang, H., Yao, X., et al. (2019). Draft genome sequence of cauliflower (Brassica oleracea L. var. botrytis) provides new insights into the $\mathrm{C}$ genome in Brassica species. Hortic. Res. 6:82. doi: 10.1038/s41438-019-0164-0
Sun, Q., Lin, L., Liu, D., Wu, D., Fang, Y., Wu, J., et al. (2018). CRISPR/Cas9mediated multiplex genome editing of the BnWRKY11 and BnWRKY70 genes in Brassica napus L. Int. J. Mol. Sci. 19:2716. doi: 10.3390/ijms19092716

Sun, Q., Zhang, E., Liu, Y., Xu, Z., Hui, M., Zhang, X., et al. (2020). Transcriptome analysis of two lines of Brassica oleracea in response to early infection with Xanthomonas campestris pv. campestris. Can. J. Plant Pathol. 43, 127-139. doi: 10.1080/07060661.2020.1775705

Sunkar, R., Li, Y. F., and Jagadeeswaran, G. (2012). Functions of microRNAs in plant stress responses. Trends Plant Sci. 17, 196-203. doi: 10.1016/j.tplants.2012. 01.010

Suravajhala, P., Kogelman, L. J. A., and Kadarmideen, H. N. (2016). Multi-omic data integration and analysis using systems genomics approaches: methods and applications in animal production, health and welfare. Genet. Sel. Evol. 48:38. doi: 10.1186/s12711-016-0217-x

Takagi, H., Uemura, A., Yaegashi, H., Tamiru, M., Abe, A., Mitsuoka, C., et al. (2013). MutMap-Gap: whole-genome resequencing of mutant F2 progeny bulk combined with de novo assembly of gap regions identifies the rice blast resistance gene Pii. New Phytol. 200, 276-283. doi: 10.1111/nph.12369

Tameling, W. I, Elzinga, S. D., Darmin, P. S., Vossen, J. H., Takken, F. L., Haring, M. A., et al. (2002). The tomato R gene products I-2 and MI-1 are functional ATP binding proteins with ATPase activity. Plant Cell 14, 2929-2939.

Tao, Y., Zhao, X., Mace, E., Henry, R., and Jordan, D. (2019). Exploring and exploiting pan-genomics for crop improvement. Mol. Plant 12, 156-169. doi: 10.1016/j.molp.2018.12.016

Taylor, J. D., Conway, J., Roberts, S. J., Astley, D., and Vicente, J. G. (2002). Sources and origin of resistance to Xanthomonas campestris pv. campestris in Brassica genomes. Phytopathology 92, 105-111. doi: 10.1094/phyto.2002.92.1.105

Tenenboim, H., and Brotman, Y. (2016). Omic relief for the biotically stressed: metabolomics of plant biotic interactions. Trends Plant Sci. 21, 781-791. doi: 10.1016/j.tplants.2016.04.009

Tewari, R. N., Chatterjee, S. S., and Swarup, V. (1979). Inheritance of resistance to black-rot (Xanthomonas campestris (Pam.) Dowson) in cabbage. Vegetable Sci. 6, 27-36.

Thakur, B. S., Korla, B. N., and Khosla, K. (2003). Inheritance of black rot resistance in late cauliflower. Ann. Agric. Res. 24, 244-248.

Thatcher, L. F., Cevik, V., Grant, M., Zhai, B., Jones, J. D. G., Manners, J. M., et al. (2016). Characterization of a JAZ7 activation-tagged Arabidopsis mutant with increased susceptibility to the fungal pathogen Fusarium oxysporum. J. Exp. Bot. 67, 2367-2386. doi: 10.1093/jxb/erw040

Thines, B., Katsir, L., Melotto, M., Niu, Y., Mandaokar, A., Liu, G., et al. (2007). JAZ repressor proteins are targets of the SCF COI1 complex during jasmonate signalling. Nature 448, 661-665. doi: 10.1038/nature05960

Tierens, K. F. M. J., Thomma, B. P. H. J., Brouwer, M., Schmidt, J., Kistner, K., Porzel, A., et al. (2001). Study of the role of antimicrobial glucosinolatederived isothiocyanates in resistance of Arabidopsis to microbial pathogens. Plant Physiol. 125, 1688-1699. doi: 10.1104/pp.125.4.1688

Tirnaz, S., and Batley, J. (2019). DNA methylation: toward crop disease resistance improvement. Trends Plant Sci. 24, 1137-1150. doi: 10.1016/j.tplants.2019.08. 007

Tonguç, M., and Griffiths, P. D. (2004). Development of black rot resistant interspecific hybrids between Brassica oleracea L. cultivars and Brassica accession A 19182, using embryo rescue. Euphytica 136, 313-318. doi: 10.1023/ B:EUPH.0000032733.47031.5f

Tonguç, M., Earle, E. D., and Griffiths, P. D. (2003). Segregation distortion of Brassica carinata derived black rot resistance in Brassica oleracea. Euphytica 134, 269-276. doi: 10.1023/B:EUPH.0000004947.37512.92

Tonu, N. N., Doullah, M. A. U., Shimizu, M., Karim, M. M., Kawanabe, T., Fujimoto, R., et al. (2013). Comparison of positions of QTLs conferring resistance to Xanthomonas campestris pv. campestris in Brassica oleracea. Am. J. Plant Sci. 4, 11-20. doi: 10.4236/ajps.2013.48A002

Tortosa, M., Cartea, M. E., Rodriguez, V. M., and Velasco, P. (2018b). Unraveling the metabolic response of Brassica oleracea exposed to Xanthomonas campestris pv. campestris. J. Sci. Food Agric. 98, 3675-3683. doi: 10.1002/jsfa.8876

Tortosa, M., Cartea, M. E., Velasco, P., Soengas, P., and Rodriguez, V. M. (2019). Calcium-signaling proteins mediate the plant transcriptomic response during a well-established Xanthomonas campestris pv. campestris infection. Hortic. Res. 6:103. doi: 10.1038/s41438-019-0186-7 
Tortosa, M., Cartea, M. E., Rodríguez, V. M., and Velasco, P. (2018a). 'Omic' profiling of B. oleracea challenged with Xanthomonas campestris pv. campestris. Acta Hortic. 1202, 63-68. doi: 10.17660/ActaHortic.2018.1202.9

Van der Biezen, E. A., and Jones, J. D. (1998). Plant disease-resistance proteins and the gene-for-gene concept. Trends Biochem. Sci. 23, 454-456. doi: 10.1016/ s0968-0004(98)01311-5

Van Wees, S. C., de Swart, E. A., van Pelt, J. A., van Loon, L. C., and Pieterse, C. M. (2000). Enhancement of induced disease resistance by simultaneous activation of salicylate- and jasmonate-dependent defense pathways in Arabidopsis thaliana. Proc. Natl. Acad. Sci. U.S.A. 97, 8711-8716. doi: 10.1073/pnas. 130425197

Vega-Álvarez, C., Francisco, M., and Soengas, P. (2021). Black rot disease decreases young Brassica oleracea plants' biomass but has no effect in adult plants. Agronomy 11:569. doi: 10.3390/agronomy11030569

Velasco, P., Lema, M., Francisco, M., Soengas, P., and Cartea, M. E. (2013). In vivo and in vitro effects of secondary metabolites against Xanthomonas campestris pv. campestris. Molecules 18, 11131-11143. doi: 10.3390/molecules 180911131

Verkerk, R., Schreiner, M., Krumbein, A., Ciska, E., Holst, B., Rowland, I., et al. (2009). Glucosinolates in Brassica vegetables: the influence of the food supply chain on intake, bioavailability and human health. Mol. Nutr. Food Res. 53, S219-S219. doi: 10.1002/mnfr.200800065

Verpoorte, R., Choi, Y. H., and Kim, H. K. (2007). NMR-based metabolomics at work in phytochemistry. Phytochem. Rev. 6, 3-14. doi: 10.1007/s11101-0069031-3

Vicente, J. G., and Holub, E. B. (2013). Xanthomonas campestris pv. campestris (cause of black rot of crucifers) in the genomic era is still a worldwide threat to brassica crops. Mol. Plant Pathol. 14, 2-18. doi: 10.1111/j.1364-3703.2012. 00833.x

Vicente, J. G., Conway, J., Roberts, S. J., and Taylor, J. D. (2001). Identification and origin of Xanthomonas campestris pv. campestris races and related pathovars. Phytopathology 91, 492-499. doi: 10.1094/PHYTO.2001.91.5.492

Vicente, J. G., Taylor, J. D., Sharpe, A. G., Parkin, I. A. P., Lydiate, D. J., and King, G. J. (2002). Inheritance of race-specific resistance to Xanthomonas campestris pv. campestris in Brassica genomes. Phytopathology 92, 1134-1141. doi: 10.1094/ phyto.2002.92.10.1134

Villeth, G. R. C., Carmo, L. S. T., Silva, L. P., Santos, M. F., de Oliveira Neto, O. B., Grossi-de-Sa, M. F., et al. (2016). Identification of proteins in susceptible and resistant Brassica oleracea responsive to Xanthomonas campestris pv. campestris infection. J. Proteomics 143, 278-285. doi: 10.1016/j.jprot.2016.01. 014

Villeth, G. R., Reis, F. B. Jr., Tonietto, A., Huergo, L., de Souza, E. M., Pedrosa, F. O., et al. (2009). Comparative proteome analysis of Xanthomonas campestris pv. campestris in the interaction with the susceptible and the resistant cultivars of Brassica oleracea. FEMS Microbiol.s Lett. 298, 260-266. doi: 10.1111/j.15746968.2009.01728.x

Voelkerding, K. V., Dames, S., and Durtschi, J. D. (2010). Next generation sequencing for clinical diagnostics-principles and application to targeted resequencing for hypertrophic cardiomyopathy: a paper from the 2009 William Beaumont Hospital Symposium on Molecular Pathology. J. Mol. Diagn. 12, 539-551. doi: 10.2353/jmoldx.2010.100043

Wan, H., Yuan, W., Ye, Q., Wang, R., Ruan, M., Li, Z., et al. (2012). Analysis of TIR-and non-TIR-NBS-LRR disease resistance gene analogous in pepper: characterization, genetic variation, functional divergence and expression patterns. BMC Genomics 13:502.

Wang, X., Wang, H., Wang, J., Sun, R., Wu, J., Liu, S., et al. (2011). The genome of the mesopolyploid crop species Brassica rapa. Nat. Genet. 43, 1035-1039. doi: 10.1038/ng.919

Wiesner-Hanks, T., and Nelson, R. (2016). "Multiple disease resistance in plants," in Annual Review of Phytopathology, eds J. E. Leach and S. Lindow (Palo Alto, CA: Annual Reviews), 229-252.
Westman, A. L., Kresovich, S., and Dickson, M. H. (1999). Regional variation in Brassica nigra and other weedy crucifers for disease reaction to Alternaria brassicicola and Xanthomonas campestris pv. campestris. Euphytica 106, 253259. doi: 10.1023/A:1003544025146

Williams, P. H. (1980). Black rot: a continuing threat to world crucifers. Plant Dis. 64, 736-742. doi: 10.1094/PD-64-736

Williams, P. H., Staub, T., and Sutton, J. C. (1972). Inheritance of resistance in cabbage to black rot. Phytopathology 62, 247-252. doi: 10.1094/Phyto-62-247

Wu, R., Haas, W., Dephoure, N., Huttlin, E. L., Zhai, B., Sowa, M. E., et al. (2011). A large-scale method to measure absolute protein phosphorylation stoichiometries. Nat. Methods 8, 677-683. doi: 10.1038/nmeth.1636

Wulf, A., Manthey, K., Doll, J., Perlick, A. M., Linke, B., Bekel, T., et al. (2003). Transcriptional changes in response to arbuscular mycorrhiza development in the model plant Medicago truncatula. Mol. Plant Microbe Interact. 16, 306-314.

Xiong, L., Lee, M.-W., Qi, M., and Yang, Y. (2001). Identification of defense-related rice genes by suppression subtractive hybridization and differential screening. Mol. Plant Microbe Interact. 14, 685-692. doi: 10.1094/MPMI.2001.14.5.685

Yang, J., Liu, D., Wang, X., Ji, C., Cheng, F., Liu, B., et al. (2016). The genome sequence of allopolyploid Brassica juncea and analysis of differential homoeolog gene expression influencing selection. Nat. Genet. 48, 1225-1232. doi: 10.1038/ ng. 3657

Ye, G., and Smith, K. F. (2008). Marker-assisted gene pyramiding for inbred line development: basic principles and practical guidelines. Int. J. Plant Breed. 2, $1-10$.

Yin, X., and Struik, P. C. (2007). “Crop systems biology," in Scale and Complexity in Plant Systems Research: Gene-Plant-Crop Relations, eds J. H. J. Spiertz, P. C. Struik, and L. H. H. van (Dordrecht: Springer), 63-73.

Yu, J., Tehrim, S., Zhang, F., Tong, C., Huang, J., Cheng, X., et al. (2014). Genomewide comparative analysis of NBS-encoding genes between Brassica species and Arabidopsis thaliana. BMC Genomics 15:3. doi: 10.1186/1471-2164-15-3

Yue, G., Hu, X., He, Y., Yang, A., and Zhang, J. (2010). Identification and characterization of two members of the FtsH gene family in maize (Zea mays L.). Mol. Biol. Rep. 37, 855-863. doi: 10.1007/s11033-009-9691-3

Zhang, R., Zheng, F., Wei, S., Zhang, S., Li, G., Cao, P., et al. (2019). Evolution of disease defense genes and their regulators in plants. Int. J. Mol. Sci. 20:335. doi: 10.3390/ijms20020335

Zheng, S. J., van Dijk, J. P., Bruinsma, M., and Dicke, M. (2007). Sensitivity and speed of induced defense of cabbage (Brassica oleracea L.): dynamics of BoLOX expression patterns during insect and pathogen attack. Mol. Plant Microbe Interact. 20, 1332-1345. doi: 10.1094/MPMI-20-11-1332

Zhu, Z., Zhang, F., Hu, H., Bakshi, A., Robinson, M. R., Powell, J. E., et al. (2016). Integration of summary data from GWAS and eQTL studies predicts complex trait gene targets. Nat. Genet. 48, 481-487. doi: 10.1038/ng.3538

Conflict of Interest: The authors declare that the research was conducted in the absence of any commercial or financial relationships that could be construed as a potential conflict of interest.

Publisher's Note: All claims expressed in this article are solely those of the authors and do not necessarily represent those of their affiliated organizations, or those of the publisher, the editors and the reviewers. Any product that may be evaluated in this article, or claim that may be made by its manufacturer, is not guaranteed or endorsed by the publisher.

Copyright (c) 2021 Shaw, Shen, Wang, Sheng, Zhao, Yu and Gu. This is an open-access article distributed under the terms of the Creative Commons Attribution License (CC BY). The use, distribution or reproduction in other forums is permitted, provided the original author(s) and the copyright owner(s) are credited and that the original publication in this journal is cited, in accordance with accepted academic practice. No use, distribution or reproduction is permitted which does not comply with these terms. 